\title{
MASTER
}

\section{The Effects of Varying Food and Density on Reproduction in Diaptomus Clavipes Schacht}

\author{
John D. Cooney \\ Carl W. Gehrs \\ Dewey L. Bunting II
}

ENVIRONMENTAL SCIENCES DIVISION

Publication No. 1182 


\section{DISCLAIMER}

This report was prepared as an account of work sponsored by an agency of the United States Government. Neither the United States Government nor any agency Thereof, nor any of their employees, makes any warranty, express or implied, or assumes any legal liability or responsibility for the accuracy, completeness, or usefulness of any information, apparatus, product, or process disclosed, or represents that its use would not infringe privately owned rights. Reference herein to any specific commercial product, process, or service by trade name, trademark, manufacturer, or otherwise does not necessarily constitute or imply its endorsement, recommendation, or favoring by the United States Government or any agency thereof. The views and opinions of authors expressed herein do not necessarily state or reflect those of the United States Government or any agency thereof. 


\section{DISCLAIMER}

Portions of this document may be illegible in electronic image products. Images are produced from the best available original document. 


\section{Printed in the United States of America. Available from}

National Technical Information Service

U.S. Department of Commerce 5285 Port Royal Road, Springfield, Virginia 22161

Price: Printed Copy $\$ 7.25$; Microfiche $\$ 3.00$

This report was prepared as an account of work sponsored by an agency of the United States Government. Neither the United States Government nor any agency thereof, nor any of their employees, contractors, subcontractors, or their employees, makes any warranty, express or implied, nor assumes any legal liability or responsibility for any third party's use or the results of such use of any information, apparatus, product or process disclosed in this report, nor represents that its use by such third party would not infringe privately owned rights. 
Contract No. W-7405-eng-26

THE EFFECTS OF VARYING FOOD AND DENSITY ON REPRODUCTION

IN DIAPTOMUS' CLAVIPES SCHACHT

John D. Cooney, Carl W. Gehrs, and Dewey $L$. Bunting II 1

ENV IRONMENTAL SCIENCES DIVISION

Publication No. 1182

1Department of Zoology, University of Tennessee, Knoxville, Tennessee.

Date Published - May, 1978

OAK RIDGE NATIONAL LABORATORY

Oak. Ridge, Tennessee 37830

operated by

UNION CARBIDE CORPORATION

for the

DEPARTMENT OF ENERGY 


\section{THIS PAGE}

\section{WAS INTENTIONALLY LEFT BLANK}




\section{ACKNOWLEDGMENTS}

The senior author wishes to thank Dr. J. T. Tanner, Department of Zoology, The University of Tennessee, for serving as a member of his graduate committee. Appreciation is also expressed to the Staff members of the Environmental Sciences Division, Oak Ridge National Laboratory, for their suggestions, technical assistance, and review of the manuscript. Consultation on statistical analysis of data by Dr. John J. Beauchamp, Computer Sciences Division, Union Carbide Corporation, and typing of the manuscript by the members of the Editorial Production Office, Environmental Sciences Division, Oak Ridge National Laboratory, are gratefully aknowledged. 


\section{THIS PAGE}

\section{WAS INTENTIONALLY LEFT BLANK}


COONEY, John D., Carl W. GEHRS, and Dewey L. BUNTING, II. 1978. The effects of varying food and density on reproduction in Diaptomus clavipes Schacht. ORNL/TM-6330. Oak Ridge Nationa Laboratory, 0ak Ridge, Tennessee. $132 \mathrm{pp.}$

Experiments were conducted to determine the effects of varying food and density on the egg production of the calanoid copepod, Diaptomus clavipes Schacht. These experiments were performed at both the population and organismic level. An attempt was also made to evaluate the feasibility of using a flow-through system to study the effects of various environmental factors on egg production in copepods.

It was found that food supply was an important factor determining rate of clutch production, number of eggs per clutch, and size of individual eggs. As food supply decreased, both the rate of clutch production and the number of eggs per clutch decreased, but the size of individual eggs increased. During periods of extreme food shortage, not only did egg production cease, but also the production of spermatophores by males. When starved females were placed under optimum feeding conditions, they produced eggs within a few days and were producing maximally within two weeks.

Egg production in the flow-through system was reduced, due primarily to food shortage. The trout chow solution which was used as food was inadequate because it was not directly utilized by the copepods. 
THIS PAGE

WAS INTENTIONALLY

LEFT BLANK 
CHAP TER

PAGE

ABSTRACT . . . . . . . . . . . . . . . . . . v

LIST OF TABLES . . . . . . . . . . . . . . . . . . . ix

LIST OF FIGURES . . . . . . . . . . . . . . . . . . . . xiii

I. INTRODUCTION AND LITERATURE REVIEW . . . . . . . . . . . 1

II. MATERIALS AND METHODS . . . . . . . . . . . . . . . 9

General Culture ................. . . 9

Measurement Techniques and Calculations....... 11

Population Studies ............... 13

Static System .................. 19

Flow-Through System . . . . . . . . . . . . 22

III. RESULTS . . . . . . . . . . . . . . . . . . 28

Population Studies . . . . . . . . . . . . 28

Temporal cycle................. . . 28

Sex ratio.................. 38

Egg production . . . . . . . . . . . . . . . . 40

Supplement ary exper iments . . . . . . . . . . 41

Static System .................. 44

Flow-Through System ................ . 64

Supp lementary experiments . . . . . . . . . . . . 74

IV. DISCUSSION . . . . . . . . . . . . . . . . 82

Population Studies .............. . . 82

Static System................. 87

Flow-through System.............. 90

V. SUMMARY AND CONCLUSIONS . . . . . . . . . . . . . 94

BIBLIOGRAPHY . . . . . . . . . . . . . . . . . . 95

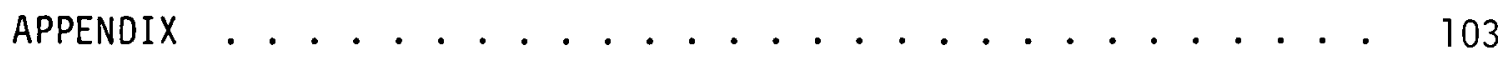




\section{THIS PAGE}

\section{WAS INTENTIONALLY LEFT BLANK}




\section{LIST OF TABLES}

TABLE

PAGE

1. Percent composition of experimental populations of Diaptomus clavipes, monitoring experiment one . . . . . .

2. Percent composition of experimental populations of Diaptomus clavipes, monitoring experiment two . . . . . .

3. Anova calculations showing the differences among the number of eggs per clutch produced in spring water and aquar ium water . . . . . . . . . . . . . . .

4. A posteriori compar ison of the mean number of eggs per $\bar{c}$ lutch produced in spring water and aquarium water using Duncan's new multiple range test .............

5. Anova calculations showing the differences among the number of clutches produced per female in aquarium water and spring water at two different food levels . . . . . 45

6. A posteriori comparison of the mean number of clutches

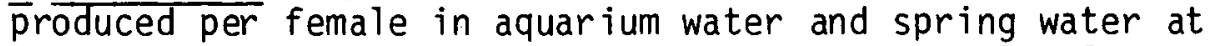
two different food levels using Duncan's new multiple range test...................... 46

7. Anova calculations showing the differences among the number of eggs per clutch at different time intervals produced by females taken from aquarium water . . . . . .

8. A posteriori compar ison of the mean number of eggs per $\bar{c}$ lutch produced at different time intervals by females taken from aquarium water using Duncan's new multiple range test.................... . 4 48

9. Mean rate of clutch production and reproductive rates for the static system calculated for each density and food level combination ............. . . 50

10. Mean number of eggs per clutch produced at three density and food levels in a static system ........... . 51

11. Means for total clutch volume produced at three density and food levels in a static system . . . . . . . . . . . 5?

12. Mean egg volumes for clutches produced at three density and food levels in a static system ........... . 53 
13. Anova calculations showing the differences among the number of eggs per clutch produced at three density and food levels in a static system ........... 55

14. A posteriori comparison of the mean number of eggs per clutch produced at three density and food levels using Duncan's new multiple range test .......... 56

15. Anova calculations showing the differences among the total clutch volumes produced at three density and food levels in a static system ............. 57

16. A posteriori comparison of the mean total clutch volumes produced at three density and food levels using Duncan's new multiple range test in a static system ....... . 58

17. Anova calculations showing the differences among the mean egg volumes for each clutch at three density and food levels in a static system ........... 59

18. A posteriori comparison of the mean egg volume for the clutches produced at three density and food levels using Duncan's new multiple range test in a static system ... . 60

19. Mean metasomal length of females at three density and food levels in a static system ........... 62

20. Mean rate of clutch production and reproductive rates for the flow-through system calculated for each density and food level combination................ 65

21. Mean number of eggs per clutch produced at three density and food levels in a flow-through system ........ 67

22. Means for total clutch volume produced at three density and food levels in a flow-through system ........ 68

23. Mean egg volumes for clutches produced at three density and food levels in a flow-through system ........ 69

24. Mean metasomal length of females at three density and food levels in a flow-through system ........ 70

25. Anova calculations showing the differences among the number of eggs per clutch produced at three density and food levels in a flow-through system ........ 71 
26. Anova calculations showing the differences among the mean egg volumes for each clutch at three density and food levels in a flow-through system ........... 72

27. A posteriori comparison of the mean number of eggs per $\bar{c}$ lutch produced at three density and food levels in a flowthrough system using Duncan's new multiple range test . . . 73

28. A posteriori comparison of the mean egg volumes for clutches produced at three density and food levels in a flow-through system using Duncan's new multiple range test . . . . . . 75

29. Mean number of eggs per clutch for females in two different lighting regimes and rates of water flow........ . 76

30. Anova calculations showing the differences among the number of eggs per clutch produced in sterile water and spring water each receiving two different types of food ..... . 78

31. Anova calculations showing the differences among the number of clutches produced per female in sterile water and spring water each receiving two different types of food . . . . . . . . . . . . . . . . 79

32. A posteriori comparison of the mean number of eggs per clutch produced in sterile water and spring water each receiving two different types of food using Duncan's new multiple range test .............. . 80

33. A posteriori compar ison of the mean number of clutches produced per female in sterile water and spring water each receiving two different types of food using Duncan's new multiple range test ............... 8

A-1. Analys is of spring water. . . . . . . . . . . . . . 104

A-2. Guaranteed analysis of Purina trout chow (size four), Ralston Purina Company . . . . . . . . . . . 105

A-3. Semi-quantitative spectrographic analysis of Purina trout chow (size four), Ralston Purina Company . . . . . 106

A-4. Constants used in the calculation of the population estimates for monitoring experiments one and two . . . . . 107

A-5. Means used to calculate population estimates for aquarium one, experiment one 
A-6. Means used to calculate population estimates for aquarium two, exper iment one ............ 109

A-7. Means used to calculate population estimates for aquarium three, experiment one ............. 110

A-8. Means used to calculate population estimates for aquarium four, experiment one ............. 111

A-9. Means used to calculate population estimates for aquarium five, experiment one ............. 112

A-10. Means used to calculate population estimates for aquarium six, experiment one .............. 113

A-11. Means used to calculate population estimates for aquarium one, experiment two .................... 114

A-12. Means used to calculate population estimates for aquarium two, experiment two .............. 115

A-13. Breeding parameters for aquaria one through six, experiment one ....................... 116

A-14. Breeding parameters for aquarium one, experiment two . . 118

A-15. Breeding parameters for aquarium two, experiment two . . . 119 


\section{LIST OF FIGURES}

FIGURE

1. Population estimates and breeding parameters for aquarium one, monitoring experiment one .. . . . . . . . . . 29

2. Population estimates and breeding parameters for aquarium two, monitoring exper iment one .. . . . . . . . . . 30

3. Population estimates and breeding parameters for aquarium five, monitoring experiment one .. . . . . . . . . 31

4. Population estimates and breeding parameters for aquarium six, monitoring experiment one .. . . . . . . . . . 32

5. Population estimates and breeding parameters for aquarium one, monitoring experiment two............ . 33

6. Population estimates and breeding parameters for aquarium two, monitoring exper iment two .. . . . . . . . . . 35 


\section{CHAPTER I}

\section{INTRODUCTION AND LITERATURE REVIEW}

The animal components of fresh waters constitute an extremely diverse assemblage of species. The majority of these are planktonic metazoans belonging to either the Rotifera or the Crustacea, represented mainly by the Cladocera in the subclass Branchiopoda and the Copepoda in the subclass Maxillopoda (Hutchinson 1967). The zooplankton play an important role in lake and pond ecosystems by occupying a position as an intermediate link in grazing food chains. Evaluation of their functional roles within aquatic systems requires analys is of their growth and reproduction in response to changing environmental parameters.

The effects of environmental factors on the population dynamics of zooplankton present complex problems which are inadequately understood due primarily to lack of knowledge concerning their general biology, environmental requirements, and interrelations within the ecosystem (Hazelwood and Parker 1961, Armitage et al., 1973). Past studies have evaluated several of these factors in an attempt to determine the more important factors affecting zooplankton populations. Temperature has been shown to affect longevity, growth, metabolism, and reproduction in aquatic poikilotherms. The degree to which these biological processes are afferted is dependent upon several factors, including range of temperatures to which an organism is exposed, exposure time, developmental stage in an organism's life history, and interaction of temperature with other environmental parameters which have profound effects on biological processes (Bunting 1974). Edmondson (1964, 1965) using the 
finite birth rate $(B)$ to determine the reproductive rates of three species of rotifer, Keratella cochlearis, Kellicottia longispina, and Polyarthra vulgaris, collected over a four-year period in the English Lake District, found that the reproductive rates were strongly related to temperature and varied with the type of food depending on its importance to each species. Chlorella sp. gave a negative correlation due presumably to its reputed antibiotic properties. Edmondson et al. (1962) estimated the reproductive rates of the calanoid copepods, Diaptomus ashlandi, $\underline{D}$. hesperus, and $\underline{D}$. sicilis in three lakes of varying limnological complexity in Washington and found that the rate at which mature females lay eggs in nature was strongly related to the abundance of phytoplankton, in that increases in phytoplankton density tended to be accompanied by, or followed by, increases in rate of production. Comita and Anderson (1959) studying a monocyclic population of Diaptomus ashlandi in Lake Washington found that the number of eggs per clutch was positively correlated with the chlorophyll data for the epilimnion when the chlorophyll data were compared with the number of eggs per clutch from the previous sampling date.

Gehrs (1972) analyzed reproduction in a natural population of Diaptomus clavipes in Oklahoma by determining the specific birth rates for adults in various seasons. He found that the birth rate increased to its peak in early spring and then steadily declined for the remainder of the year. Analysis of the three main factors which could affect the specific birth rate (male to female ratio, proportion of ovigerous females, and mean number of eggs per clutch) revealed that the mean number of eggs per clutch was the most important. He found a highly 
significant positive correlation between the mean number of eggs per clutch and the chlorophyll data for early spring while a similar analysis for the remainder of the year revealed a significant inverse correlation; however, the quality of the food changed through the year with filamentous and colonial algae predominating in the spring which may be of no food value to diaptomids, so these correlations do not imply causation. Gehrs also found an inverse relationship between density during development and mean number of eggs per clutch and concluded that density may be the regulating factor in controlling clutch size, and hence reproduction, as long as the temperature was within the range necessary for reproduction in this population.

Ravera (1955) found that the reproductive rate in four species of pelagic copepods in Lake Maggiore increased with numerical depressions of the population. Wright (1965) found that the largest mean number of eggs per brood was found during periods of low density in populations of Daphnia schodleri from Canyon Ferry Reservoir in Montana. Whitehouse and Lewis (1973), however, found that in laboratory populations of Cyclops abyssorum, although female size decreased with increasing density, clutch size, total number of clutches, and total egg production per female increased with increasing density. Frank et al. (1957) found in a laboratory study of Daphnia pulex that as density increased, survivorship increased, birth rate decreased, and growth was lowered. They also found that the same maximum population size was achieved but at different rates; only at the highest density levels was stunting absolute. They concluded that density may have certain significant 
consequences before some limiting factor, like food, was totally exploited.

In a study to analyze the development of Daphnia magna populations under controlled conditions, Pratt (1943) found that mean population size at $18^{\circ} \mathrm{C}$ was about two and one-half times as great as at $25^{\circ} \mathrm{C}$. He stated that this was consistent with the common experience that populations reach greater densities in cold regions than in warm regions. This referred to the equilibrium population rather than productivity in terms of turnover rates. He also showed that isolated females had a higher reproductive rate than crowded females and at low densities the reproductive rate was higher at $25^{\circ} \mathrm{C}$ than it was at $18^{\circ} \mathrm{C}$; at high density conditions, the reverse was true.

In a detailed case study, Slobodkin (1954) reported that populations of Daphnia obtusa were larger at $15^{\circ} \mathrm{C}$ than at $20^{\circ} \mathrm{C}$. He felt that this might be due to a greater expenditure of energy at $20^{\circ} \mathrm{C}$ since both temperatures received a constant supply of food. He also found that population size was linearly related to food supply and demonstrated the absence of a direct density effect. He concluded that there was no significant interaction between Daphnia in the population except in their competition for food. He also interpreted Pratt's (1943) results in terms of competition for food. At low densities, the limit to the reproductive capacity was in part dependent upon the amount of food which the animal could consume and was not particularly dependent upon the amount of food available, thus an animal with a high filtering rate would show a higher reproductive rate than an animal with a low filtering rate. This difference in filtering rate could be induced by a 
temperature difference. As the density of the animals increased, the amount of food became more and more a limiting factor.

Egg size has also been observed to vary in response to changing environmental factors. Wesenberg-Lund (1904, cited in Hutchinson 1951) found that in three copepods which he studied not only did clutch size decrease but egg size increased as the seasons progressed from spring to sumer. This relationship was also found in Eudiaptomus gracilis and $E$. graciloides in several Polish lakes studied by Czeczuga $(1959,1960)$. Comita (1964) studying the energy budget of Diaptomus siciloides found that the energy involved in egg production fluctuated very little over the year. The number of eggs per clutch varied from 2 to 19 during the year; however, the size of individual eggs also varied during this period being larger in smaller clutches thus accounting for the small fluctuations in total volume. Agar (1914) showed in a monoclonal population of Simocephalus exspinosus that when the size of the parent was constant, the size of the eggs, as estimated by the size of the developing young, varied inversely to their number. These measurements were made on females in the first adult instar and the young liberated by them. Slobodkin (1954) noticed that starved Daphnia obtusa produced larger eggs than we 11-fed ones. Green $(1956,1964)$ found that lake dwelling species of Daphnia produced fewer but larger eggs than pond dwelling species of the same size. He believed that this tendency to produce large eggs may have evolved in association with the lower availability of food in lakes compared with ponds. In Lake Seven, Pyatakov (1956, cited in Green 1966) noted that when food was scarce, the number of eggs produced by Daphnia fell to very low levels, but each egg was 
1 arge. The largest eggs were produced when a single egg was laid in each brood and the ovaries functioned alternately. Agar (1913) found that nutrition was not the only factor affecting egg size. He found that by raising the temperature, the size of the young of Simocephalus vetulus was reduced.

Many investigators have suggested that the number of eggs produced per clutch by zooplankton is a function of the size of the adult female which could be affected by various environmental factors. Deevey, in a series of studies in north temperate waters $(1960,1964)$ and in south temperate waters (1966) found two different patterns of copepod length cycles. In one, noted in the coastal waters of the northeastern United States where there was an exceptionally wide range of temperature of up to $20^{\circ} \mathrm{C}$ or more, copepod size inversely followed the annual temperature cycle. In the other, found in the waters of Great Britain, western Europe, and New Zealand, where the temperature range was narrower, less than $14^{\circ} \mathrm{C}$, the length variations followed the annual. phytoplankton cycle, but temperature was also important. McLaren (1963) pointed out that temperature and concentration of food were of ten not independent variables in nature. He concluded from a review of the literature that the concentration of food had little direct effect on the length of copepods, although it did influence their rate of development which in turn determined the temperatures that the animals experfenced during growth and thereby affected length indirectly.

Cole (1966) found that calanoid copepods from temporary ponds in Arizona were larger in size and produced larger clutches of eggs than the same species in permanent waters. He believed that this could be 
attributed to a better nutritional supply in ephemeral waters. Maly (1973), studying populations of Diaptomus shoshone and $\underline{D}$. coloradensis from two high altitude lakes in Colorado, observed that larger individuals with larger clutches were found in lakes where the density of developing individuals was low. Ravera and Tonelli (1956) showed a positive correlation for Arctodiaptomus bacillifer and Acanthodiaptomus denticornis between body size, clutch size, and rate of water renewal in a number of high altitude lakes in the Alps. These authors suggested that larger females which were potentially capable of carrying a larger number of eggs, were selectively evolved in response to the need to counterbalance high mortality caused by loss of individuals in the outflowing water by higher egg production. Bayly (1962) found a comparable relationship but he rejected the idea of genetic selection because of the large seasonal variation which he observed in egg numbers between different populations of Boeckella propinqua. Smyly (1968) found that large adult female Diaptomus gracilis does not always lay the maximum number of eggs which she is capable of laying since the number of eggs per clutch change with age and availability of food. Brooks (1946) reported that in natural populations of Daphnia retrocurva, the smallest adults produced more eggs than the larger ones when they were starved.

Although calanoid copepods, especially those from the genus Diaptomus, comprise a major component of many freshwater communities, few controlled laboratory studies have been carried out due to difficulties in culturing (Robertson et al., 1974). Diaptomus clavipes Schacht was chosen for this study since it was the first freshwater 
calanoid copepod to be successfully maintained in culture (Robertson et a1., 1974) and a great deal was known about its life history through both laboratory and field studies (Cole 1966, Siefken and Armitage 1968, Hardin 1972, Gehrs 1974, Gehrs and Hard in 1974, Gehrs and Robertson 1975).

The objectives of this study were twofold: (1) to determine the effects of varying food and density on egg production, at both the population and organismic level, when temperature remained constant, and (2) to evaluate the feasibility of using a flow-through system to study the effects of various environmental factors on egg production in copepods. 
CHAPTER II

MATERIALS AND METHODS

General Culture

Original stock cultures of Diaptomus clavipes were gathered in 1973 from a small man-made impoundment in Cleveland County, Oklahoma (See Gehrs 1972 for description of impoundment). Self-propagating cultures have since been maintained at Oak Ridge National Laboratory in 180-liter-capacity glass aquaria. During the present study, new cultures were started in smaller, 38-liter capacity aquaria, and maintained at $21^{\circ} \mathrm{C} \pm 1^{\circ} \mathrm{C}$ in a Percival controlled environment chamber. All animals used in testing were removed from these aquaria.

The water used for culturing and testing was obtained from a spring located on the Oak Ridge Reservation and pumped directly into the laboratory: Before entering the laboratory, the spring water passed through a small sand filter which removed the large particulate matter. The quality of the water remained relatively constant throughout the year (see Table A-1). During th is study, the $\mathrm{pH}$ ranged from 6.5 to 7.5 while the dissolved oxygen varied from seven to nine parts per million (ppm). The temperature of the incoming water varied seasonally between $8^{\circ} \mathrm{C}$ and $18^{\circ} \mathrm{C}$. At some times, algae, primarily Scenedesmus sp., passed through the filter and reproduced, thus providing an unwanted food source for the animals if stored for any length of time. During heavy rains, the water became very turbid with sediment. All water was filtered through 
250-mesh stainless steel bolting cloth and allowed to equilibrate at the desired temperature for 24 hours before it was used in testing.

The food material used in culturing and testing was a modification of a mixture first developed by Biesinger and Christensen (1972) for Daphnia magna and used successfully by Robertson et al. (1974) for Diaptomus clavipes. The food was prepared by mixing 10 grams (g) of Purina trout chow (see Tables A-2 and A-3) with 250 milliliters (ml) of distilled water for five minutes at high speed in a Sears blender. The entire mixture was strained through 250-mesh stainless steel bolting cloth. The material retained on the bolting cloth was discarded and the filtrate served as the feeding solution. This was kept in a stoppered bottle in the refrigerator at $10^{\circ} \mathrm{C}$ when not in use so that bacterial growth and other changes were retarded. If the food solution was not used within a week, it was discarded and a new supply prepared. This food has the advantage that it can be made up to the same specifications each time it is produced, thus permitting control of the relative amounts of food added to different cultures by changing the concentration of trout chow per unit volume of distilled water or by changing the amount of food solution added to each culture.

In order to obtain large numbers of immature animals, a stock culture was filtered and early stage copepodids were removed. These animals were isolated in $100 \mathrm{ml}$ beakers containing $80 \mathrm{ml}$ of spring water. The beakers were covered with watch glasses to reduce evaporation and then placed in the same controlled environment chamber where the stock cultures were kept. The animals were fed daily $1 \mathrm{ml}$ of food solution 
in a concentration of $2.5 \mathrm{~g} /$ liter. At the onset of sexual maturity, copepodid stage six, the animals were used in testing.

Measurement Techniques and Calculations

During some experiments, it was necessary to measure ovigerous females and a subsample of the eggs which they produced. All measurements were made under a compound microscope with a Vickers A. E. I. image-splitting eyepiece using either a magnification of $40 \mathrm{x}$ or $100 \mathrm{X}$. The eyepiece was calibrated with a stage micrometer. In order to determine the precision of the instrument, numerous measurements were made of a 0.1 millimeter $(\mathrm{mm})$ section of a stage micrometer at the two magnifications. All measurements were within one vernier unit of each other. At a magnification of $40 \mathrm{x}$, one vernier unit equaled $2.5 \times 10^{-3} \mathrm{~mm}$, while at $100 \mathrm{x}$, one vernier unit equaled $8.89 \times 10^{-4} \mathrm{~mm}$.

The length of the metasome excluding the wings was measured on all ovigerous females at a magnification of $40 \mathrm{x}$. This measurement was chosen over the total length measurement, since the urosome may bend or the segments telescope or contract when immobilized, thus giving variable measurements (Marshall and Orr 1955).

The eggs, after they had been removed from the sac, were covered with water to prevent desiccation and then measured at a magnification of 100x. The greatest and least diameters were measured. The depth of the egg was assumed to be equal to the least diameter. This was verified by measuring the diameter in various positions on the egg. The formula used in calculating egg volumes was: 


$$
V=(1 / 6) k^{3} \pi a b^{2}
$$

where:

$$
\begin{aligned}
& V=\text { egg volume in } \mathrm{mm}^{3} \\
& k=8.89 \times 10^{-4} \mathrm{~mm} / \text { vernier unit } \\
& a=\text { greatest diameter in vernier units } \\
& b=\text { least diameter in vernier units } \\
& \pi=3.1416
\end{aligned}
$$

A subsample of 25 eggs per clutch was originally measured to obtain a mean egg volume for each clutch. The variation in egg volumes with in a clutch was found to be small, therefore, the size of the subsample was reduced to 15 eggs. This was determined by calculating a weighted variance based on 25 clutches where all the eggs had been measured and inserting this value into a formula used for the determination of sample size (Snedecor and Cochran 1967) which is as follows:

$$
\delta^{2}=\frac{s^{2} t^{2} 0.05}{n}
$$

where:

$$
\begin{aligned}
& s^{2}=\text { weighteat sample variance } \\
& t=t-v a l u e \text { at } 0.05 \text { level for } n-1 \text { degrees of freedom } \\
& n=\text { sample size } \\
& \delta=\text { population difference }
\end{aligned}
$$


It was found that for a sample size of 15 eggs, the population difference was $6 \times 10^{-5} \mathrm{~mm}^{3}$ while increasing the sample size to 25 or 30 eggs reduced this difference by on $1 y 2 \times 10^{-5} \mathrm{~mm}^{3}$.

The total clutch volume was determined by first calculating the mean individual egg volume from the subsample and then multiplying this value by the number of eggs in the clutch. In several cases, the number of eggs in a subsample equaled the total number of eggs in the clutch; thus, two possible estimates could be made for each clutch, one based on the method previously discussed, and one based on summing all the individual egg volumes. The differences between the two estimates were compared for a sample of 50 clutches using a t-test for paired comparisons (Sokal and Rohlf 1969). This test was not significant at the 0.05 leve 1, thus indicating that the method based on mean egg volume provided a reasonable estimate of total clutch volume.

\section{Population Studies}

Two experiments were conducted in order to monitor the changes associated with the development and growth of laboratory populations of Diaplumus clavipes. In mon1toring experiment one, six glass aquaria with stainless steel frames and a surface area of 1262 square centimeters $\left(\mathrm{cm}^{2}\right)$ were filled with 30 liters of spring water. This volume was maintained throughout the study by the addition of distilled water. A clear plexiglass cover was placed over each aquarium to reduce evaporation and the aquaria were then allowed to equilibrate to laboratory conditions for a period of one week. The temperature conditions were not strictly controlled and ranged from $20^{\circ} \mathrm{C}$ to $25^{\circ} \mathrm{C}$, averaging $21^{\circ} \mathrm{C}$, 
during the study period. The light intensity at the water's surface was approximately 70 to 80 foot-candles with a photoperiod of 12 hours light and 12 hours dark.

Adult animals were removed from stock cultures and isolated in $100 \mathrm{ml}$ beakers containing spring water to insure that injured animals or ovigerous females were not placed in the aquaria. After two days, thirty males and thirty females were selected and placed in each aquarium. At three- to four-day intervals, each aquarlum rece ived 3 iml of food solution in a concentration of $40 \mathrm{~g} / \mathrm{liter}$.

At approximately weekly intervals, 24 samples were taken from each aquarium with a clear plexiglass tube. After three weeks, the number of samples was reduced to 10 per aquarium. A sample was obtained by inserting the tube to the bottom of the aquarium, sealing it on the top and bottom with rubber stoppers, and then removing it. This technique effectively removed a complete column of water with very little disturbance and has been used successtuily with copepods by Robertson el al. (1974). The contained animals were enumerated by general life stage, and in adults, by sex, in the tube with the aid of a high intensity light and then returned to the aquarium using the reverse procedure. If the sample was too large to count in the tube, it was emptied into a beaker and then counted. When ovigerous females were present, they were removed, immobilized in an ice bath, placed under a dissecling microscope, and the number of eggs per clutch determined. This procedure appeared to have little adverse effect on these animals. Each sample was completely analyzed and returned to the aquarium before another sample was removed, thus, each sample estimated the total population 
with no bias due to removal of animals. Samples were taken at time intervals of at least 15 minutes to reduce behavior modification due to possible disturbance caused by previous sampling.

During the first three sampling periods, a plexiglass tube having an inside diameter of $3.1 \mathrm{~cm}$ was used. In later periods, a larger tube with an inside diameter of $4.1 \mathrm{~cm}$ was substituted for the smaller tube. This tube was more efficient and the number of samples collected was reduced from 24 to 10 per aquarium with very little loss in the volume sampled which was approximately 14 percent of the total volume of the aquarium.

During the first sampling period, samples were randomly collected and only the adults enumerated. Upon examination of these samples, it was apparent that more animals were collected along the sides of the aquarium than in the middle. This was verified by setting up two aquaria, one with a density of 120 adults and the other with a density of 240 adults. One hundred random samples were withdrawn from each aquarium during the course of two days and the total number of adults per sample was enumerated. The samples were sorted according to where they had been colilected, either along the sides or in the middle, and then the data were subjected to a median test (Conover 1971). In both aquaria, more adults were collected along the sides and this was significant at the 0.05 level for a density of 120 adults and at the 0.01 level for a density of 240 adults. This indicates that a difference does exist between the two areas and it becomes more pronounced as the density increases, therefore, it was decided that a stratified sampling procedure should be employed with one-half the samples being collected 
in each area. This was accomplished by placing a grid system over each aquarium. The size of each grid was determined by the outside diameter of the plexiglass tubes, thus, the number of grids in the system and the total volume per area varied with the size of the plexiglass tube. For each sampling period, grids from each area were randomly selected for collection of samples.

After nine weeks of sampling, monitoring experiment one was discontinued while most of the populations were still increasing in size. It was evident that most of the aquaria followed the same pattern and could be considered as replicates, therefore a second monitoring experiment was initiated using only two aquaria. These were set up in the same manner as in the previous experiment except that the initial density was increased to 60 males and 60 females and they received $6 \mathrm{ml}$ instead of $3 \mathrm{ml}$ of food solution, twice weekly. The aquaria were monitored for a period of 29 weeks using the large tube exclusively. In this experiment, one of the five samples along the sides was always collected in a corner. This was done because it was noted in the previous experiment that when corner samples were collected, they consistently contained more animals than the other samples. During the last five sampling periods, only six samples were collected per aquarium.

Although sampling ceased after 29 weeks, the aquaria still received food twice weekly. Visual observations showed that the populations were remaining at low levels with no indications of increasing. A series of supplementary experiments were run in order to attempt to isolate factors which may have caused this phenomenon. Water was taken from each of the two aquaria, filtered through a number 50 Whatman 
filter, and then placed in one liter beakers, five beakers for each aquarium. Ten additional beakers contained spring water. Adults were removed from stock cultures and placed in these beakers at a density of three males and one female. They were observed daily for ten days and the number of clutches and the number of eggs per clutch were recorded for each female. Each beaker received $5 \mathrm{ml}$ of food solution in a concentration of $2.5 \mathrm{~g} /$ liter. Water was changed at five day intervals.

Another experiment lasting fifteen days was set up in the same manner as in the previous experiment. However, all the test water was removed from the same aquarium and two different concentrations. of food were used. Five beakers of test water and five beakers of spring water each received $5 \mathrm{ml}$ of food solution in a concentration of $2.5 \mathrm{~g} / \mathrm{liter}$ while the other beakers received $0.2 \mathrm{ml}$ of food solution in a concentration of $40 \mathrm{~g} / \mathrm{liter}$ which was the same quantity delivered to each aquarium.

A final experiment was conducted using adults taken from the aquaria used in the study. Ten ovigerous females were collected, and their clutches removed and counted. Each female was placed with three males in one liter beakers containing spring water and fed $5 \mathrm{ml}$ of food solution in a concentration of $2.5 \mathrm{~g} /$ liter, daily, for 21 days. The number of clutches produced and the number of eggs per clutch were recorded for each female.

Population estimates were computed based on the following formula:

$$
N=\frac{k_{s} \bar{x}_{s}+k_{m} \bar{x}_{m}}{c}
$$


where:

$$
\begin{aligned}
k_{s}= & \text { proportion of total volume in the area along the sides } \\
k_{m}= & \text { proportion of total volume in the area in the middle } \\
\bar{x}_{s}= & \text { mean number of animals per sample for the area along the } \\
& \text { sides } \\
\bar{x}_{m}= & \text { mean number of an imals per sample for the middle area } \\
c= & \text { volume of water in liters per sample } \\
N= & \text { number of animals per liter }
\end{aligned}
$$

The values for the constants varied with the size of the plexiglass tube which was used. These values can be found in Table A-4. In the second monitoring experiment, samples were collected in the corners during each sampling period. These corner samples were compared with the samples collected along the sides using a median test. There was no significant difference among the samples at the 0.05 level, so the corner samples were combined with the other samples to obtain the mean for the area along the sides.

The reproductive rate was calculated according to Edmondson (1960, 1962) using the finite birth rate formula:

$$
B=\frac{E}{D}
$$

where:

$$
\begin{aligned}
& B=\text { the number of eggs per female per day } \\
& E=\text { the mean number of eggs per female } \\
& D=\text { duration of egg development in days }
\end{aligned}
$$


The duration of egg development was considered to be two days. This was the time determined by Hardin (1972) for Diaptomus clavipes at $21^{\circ} \mathrm{C}$ in a laboratory experiment.

\section{Static System}

A series of four experiments was conducted in a static system in order to determine if altering food and density levels influenced reproduction. Each experiment consisted of three fixed density levels, each receiving the same feeding regime. One-liter beakers were used as the experimental containers and these were filled to capacity with spring water. Newly matured males and females in equal numbers were placed in each container at densities of 2,6 , and 12 animals. The number of females per density level was constant, thus, for each container at a density level of 12 animals, two containers were used at a level of six animals and six containers at a level of two animals. After the first two experiments, the lowest density was increased to three animals per container by the addition of an extra male. This was initiated due to lack of reproduction in some of the containers at this level. The usua 1 number of containers for each experiment was 18 , however in the first experiment only nine containers were used. The duration of the experiments was 21 days, except aga in in experiment one which was terminated after 14 days. All containers were kept in a controlled environment chamber at $21^{\circ} \mathrm{C} \pm 1{ }^{\circ} \mathrm{C}$. The light intensity at the level of the containers was 500 foot-candles with a photoperiod of 12 hours light and 12 hours dark. Each container was examined daily and the following noted: (1) presence of dead animals, (2) presence of ovigerous females, 
(3) condition of the ovaries, (4) presence of spermatophores on the females, and. (5) general condition of the animals. During the first two days, replacement animals were of the same sex as those which had died; however, after this time, all dead animals were replaced with males. This was necessary since individual females could not be recognized at the higher density levels. This was important since replacements were fed at different rates which might have affected their egg production if used in the experiments and biased the results. All females were removed and examined under a dissecting microscope. This was accomplished by pipetting individuals from the containers and placing them on a depression slide. By removing the excess water, the females were immobilized. The condition of the ovaries was determined using the criteria of Marshall and Orr (1952). The number of spermatophores present on each female was counted and when possible, the length of time each was carried. When ovigerous females were present, their egg clutches were removed with the aid of two camel-haired brushes. The eggs were separated from the sac and then counted. The number of abnormal eggs was noted for each clutch. The length of the females and the diameters of a subsample of the eggs they produced were then measured. After examination, the animals were transferred to beakers containing clean spring water and then replaced in the controlled environment chamber. When all the females in any one container had died, it was removed from the experiment.

Four feeding regimes were used during this study. In experiment one, the animals were not fed at a11. During experiment two, the animals were not fed for seven days and then fed $10 \mathrm{ml}$ of food solution in 
a concentration of $2.5 \mathrm{~g} /$ liter. In experiment three, the animals were fed $10 \mathrm{ml}$ of food solution in a concentration of $5 \mathrm{~g} / 1 \mathrm{titer}$. In the final experiment, the animals were originally fed $10 \mathrm{ml}$ of food solution in a concentration of $10 \mathrm{~g} /$ liter. This quantity of food proved excessive, lowering the dissolved oxygen level to near anoxic conditions. Although the animals were not killed, they appeared to be stressed, since they produced very few clutches. This experiment was halted and another experiment with new animals was initiated. The quantity of food solution supplied to the animals was reduced to $5 \mathrm{ml}$, however the water was changed on alternate days instead of daily.

Due to the changing sex ratios throughout the experiment, an additional experiment was conducted to determine if sex ratio had any effect on the number of clutches produced per female or the number of eggs per clutch. Twenty-five one-liter beakers were filled to capacity with spring water. One female was placed in each beaker. These females had been removed from stock cultures and then isolated for two days before they were used. Males were then placed in all the beakers at five different sex ratios ranging from one to one to five to one. Five beakers were maintained at each sex ratio. The beakers were examined daily for 15 days, and when ovigerous females were present, their clutches were removed and the number of eggs per clutch was noted. Each beaker was supplied with $5 \mathrm{ml}$ of food solution in a concentration of $2.5 \mathrm{~g} / 1 \mathrm{iter}$, daily. The water was shanged at 5- to 7-day intervals, and all dead animals were replaced with animals of the same sex. 


\section{Flow-Through System}

A series of four experiments was performed to examine the feasibility of using a flow-through system to detect differences in reproduction among animals maintained at various density levels and feeding regimes. The system was designed so that water would continuously flow through the experimental containers and the duration of feeding could be precisely determined.

Three rectangular aquaria, each with a capacity of 180 liters, were used in the construction of the flow-through system. Two aquaria were situated side by side while the third was positioned approximately one meter above them and served as a reservoir for the spring water. The spring water flowed at a rate of two liters per minute into a Dynoflo filter containing activated charcoal and glass wool. Water from the reservoir was siphoned into the filter and mixed with the incoming spring water, and then pumped back into the reservoir at a rate of 8 liters per minute. This water was then heated to $21^{\circ} \mathrm{C}$ and maintained at this level using two Y.S.I. Thermistemp Controllers. The temperature usually remained within one degree of the desired temperature. The heated water was circulated with the aid of the filter pump and by aerating with a series of air stones situated along the bottom. The reservoir aquarium contained a standpipe which reduced the maximum volume to 165 liter. All excess water flowed over this standpipe and was drained away, thus maintaining a constant volume in the reservoir when there was a slight overflow. The light intensity ranged from 30 to 40 
foot-candles at the surface of the water with a photoperiod of 12 hours light and 12 hours dark.

The two lower aquaria were equipped with a system of glass tubing situated along the inside perimeter of each aquarium and interconnected at regular intervals with $5 \mathrm{~cm}$ sections of Tygon tubing. The tubing had an inside diameter of $5 \mathrm{~mm}$ and was supported $32 \mathrm{~cm}$ above the bottom by stainless steel wire. In each aquarium, nine sections of Tygon tubing were perforated and $15 \mathrm{~cm}$ sections of teflon tubing with an inside diameter of $0.4 \mathrm{~mm}$ were inserted into each of these sections. Another section of Tygon tubing was perforated allowing water to flow directly into each aquarium.

The reservoir was connected to the two lower aquaria with glass tubing and the water was conducted through this using a gravity feed siphon system. The rate of spring water input to each of the lower aquaria was approximately $750 \mathrm{ml}$ per minute with an average of $30 \mathrm{ml}$ of water per minute flowing into each experimental container, while the rest emptied directly into the aquaria. The excess water was removed through a network of perforated tubing situated along the bottom of each aquarium. The two lower aquaria were maintained at a volume of 100 liter each. Periodically, the drainage system had to be backflushed to remove food particles which clogged the system. The input and output rates sould he adjusted by using hose clamps which constricted the Tygon tuhing and regulated the flow.

A styrofoam grid containing 18 blocks was constructed and placed in each aquarium. Nine experimental containers were placed in each aquarium in alternate grids, so that no two containers were next to each 
other. The containers were rotated daily to reduce the possible effect of variable food and water flows.

The containers were constructed of plexiglass with the same approximate internal dimensions as a one liter beaker. Five $4.5-\mathrm{cm}$ holes were drilled in each container, one in the bottom and four in the sides. These holes were covered with 250 -mesh stainless steel bolting cloth. After the first two experiments, the bolting cloth covering the bottom was replaced with 58 -mesh bolting cloth due to clogging of the mesh with food resulting in occasional overflows. A styrofoam collar was attached to each container which allowed it to float at a fixed level in the water. The collar was 13.5 centimeters square and $2.5 \mathrm{~cm}$ thick. This maintained a constant volume of one liter in the containers even if the volume of the aquaria fluctuated. Four smaller holes were drilled near the top of the containers to allow for the insertion of the food and water hoses.

The food solution was delivered in a rnnreantration of $5 \mathrm{~g} /$ liter. This was prepared in a concentrated form and then diluted in a 26-liter capacity plastic bottle. This bottle was at the same height as the reservoir and the food solution was magnetically stirred throughout the duration of feeding to prevent settling of the mixture. Eighteen teflon tubes and one glass tube were inserted into a series of rubber stoppers and then placed into the bottle. The top rubber stopper provided an airtight seal on the bottle and this was secured with a screw cap. Small segments of flexible Tygon tubing were placed on the ends of the teflon tubing and then connected to the containers. The food input was controlled using hose clamps. 
Initial siphoning of the food was accomplished by forcing compressed air through the glass tube which pressurized the bottle. The compressed air hose was then removed. As the food solution flowed out, air came in through the glass tube keeping the interior pressure constant during the feeding period. This kept the flow of food constant to each container. After each feeding, all containers were removed and placed in the reservoir. This effectively removed most of the food which was previously delivered.

Each container was placed in a stainless steel pan with spring water, examined, and then cleaned. The observations were the same as in the static system. The two lower aquaria were emptied, rinsed, and refilled. The plastic food bottle was cleaned of any remaining food and the hoses flushed with distilled water.

Eighteen containers were used in each experiment, nine per aquarium. The duration of the experiments was 14 days for experiments one and four and 21 days for experiments two and three. In experiment one, the adults were collected from stock cultures, isolated for two days, and then placed in the containers at the same density levels as in the static system. This was a preliminary experiment to establish baseline data to determine if the animals could subsist and reproduce in the containers when no food was added. In the remaining experiments, newly matured animals were used and the duration of feedinq was a lțered. In experiment two, the animals were fed for 1.5 hours at a rate of $15 \mathrm{ml}$ per minute per container. On two occasions, the bolting cloth became clogged with food and some containers overflowed with loss of animals. In these cases, the containers were refilled with new animals. In 
experiments three and four, the duration of feeding was increased to three hours and six hours, respectively, at a rate of 7 to $8 \mathrm{ml}$ of food per minute per container. In experiment four, this necessitated refilling the plastic bottle.

Due to the reduced reproduction in the flow-through system, it was decided to examine three variables which differed from the static system. These were flow of water, light intensity, and administration of food. In the first supplementary experiment, four containers were placed in each aquarium. Newly matured adults were placed in each container at a density of six animals, three males and three females. One aquarium was kept at the same light intensity as during the experiments ( 30 to 40 foot-candles), while in the other aquarium two fluorescent light fixtures were placed over the top, approximately $17 \mathrm{~cm}$ from the water's surface. This increased the light intensity to 300 footcandles. Two containers in each aquarium were attached to the water flow continuously while the others were attached only during feeding. Food, in a concentration of $5 \mathrm{~g} /$ liter, was administered for three hours at a rate of 7 to $8 \mathrm{ml}$ per minute per container.

The containers were examined daily for 14 days, and the number of clutches produced per container and the size of each clutch was noted. After this time, the remaining animals were removed and placed in pairs in $100 \mathrm{ml}$ beakers and fed $1 \mathrm{ml}$ of food solution in a curceritration of $2.5 \mathrm{~g} /$ liter daily, for an additional 14 days.

A final experiment was conducted to determine if the animals were utilizing the trout chow solution or the microfauna which naturally occur in the spring water and were enhanced by the addition of the food 
solution. Twenty $100 \mathrm{ml}$ beakers were filled with $80 \mathrm{ml}$ of spring water. One half of these beakers contained spring water which had been heated to $120^{\circ} \mathrm{C}$ in a Castle Sterilizer for one hour, while the others contained natural spring water. Newly matured animals were placed in pairs in each beaker. The food solution was in a concentration of $2.5 \mathrm{~g} / 1$ iter and was prepared in the same manner as in previous experiments except that one-half was removed and sterilized. One half of the beakers in the spring water and in the sterile water received the regular food solution while the other half received the sterilized food. The beakers were examined daily for ten days and the number of clutches produced and the size of each clutch was noted. The water was changed at five-day intervals. Dead animals were replaced; this, however, contaminated the sterile water with Scenedesmus $\mathrm{sp}$. which were egested by the animals in a viable state. This additional food source may have increased the clutch production in some beakers. 
CHAPTER III

RESULTS

Population Studies

Population estimates and the following breeding parameters, proportion of ovigerous females, mean number of eggs per clutch, finite birth rate $(B)$, and male to female ratios, were computed based on the data compiled in the two monitoring experiments and presented in the form of graphs (Figures 1-6). The means used in drawing these graphs are shown in Tables A-5 to A-15. In monitoring experiment one, six populations were sampled during a nine-week period and four of these exhibited simi1 ar behavior in their growth and development (Figures 1-4). The population in aquarium three, however, showed little change in size during the study period while the population in aquarium four declined to extinction after five weeks. In the second monitoring experiment, two populations were sampled for twenty-nine weeks. These two populations were similar in their growth and development but differed in their magnitudes (Figures 5-6).

\section{Temporal cycle}

The composition of the populations in the different aquaria exhibited similar patterns of variation during the study period. In the first set of aquaria which were started with 60 adults each, initial growth was rapid (Figures $1-4$, Graphs $A-D$ ). During the nine-week sampling period, the immature stages were predominant; at times, comprising up to 97 percent of the total population (Table 1). The nauplier stages 


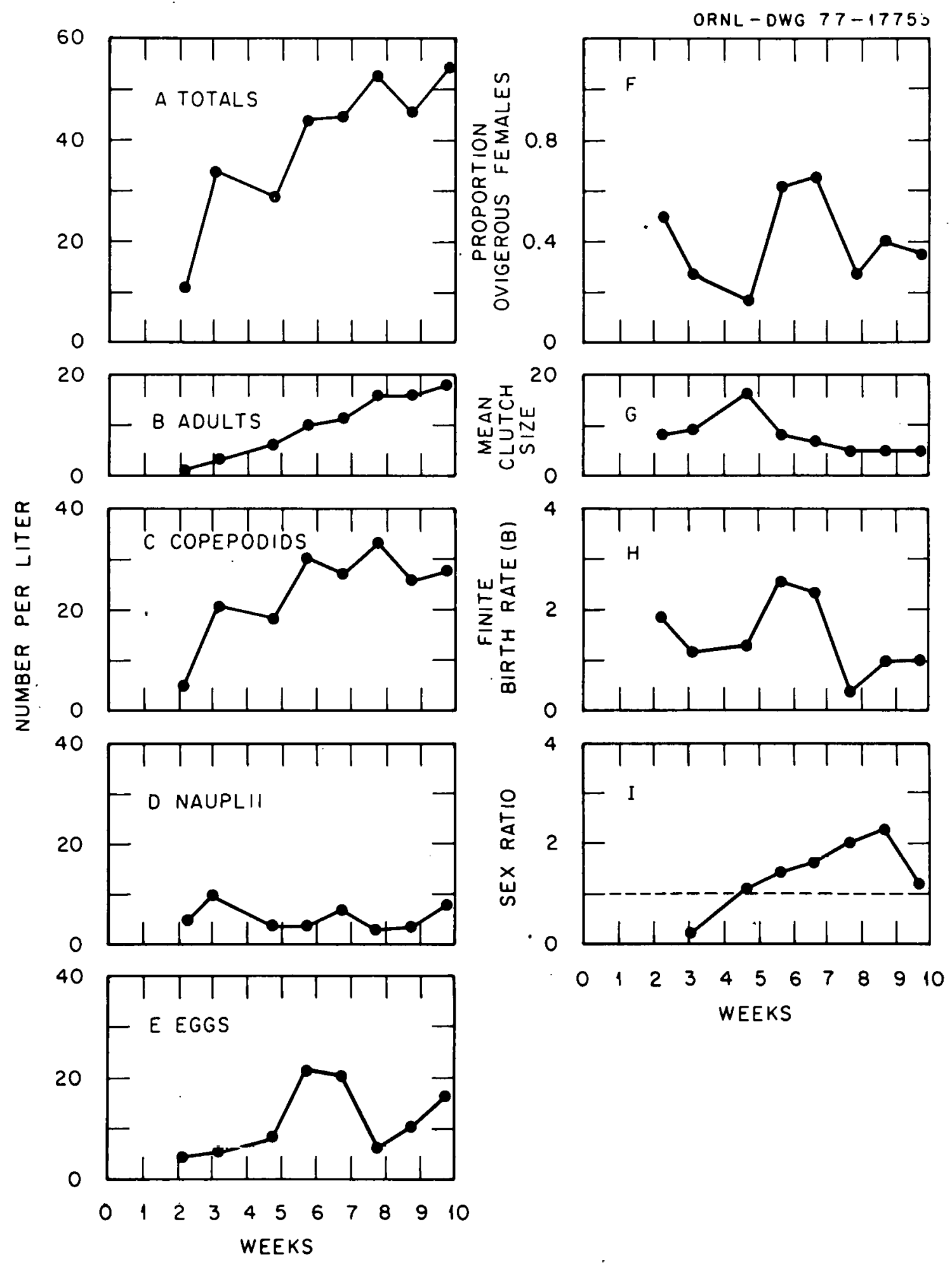

Fig. 1. Population estimates and breeding parameters for aquarium one, monitoring experiment one. 


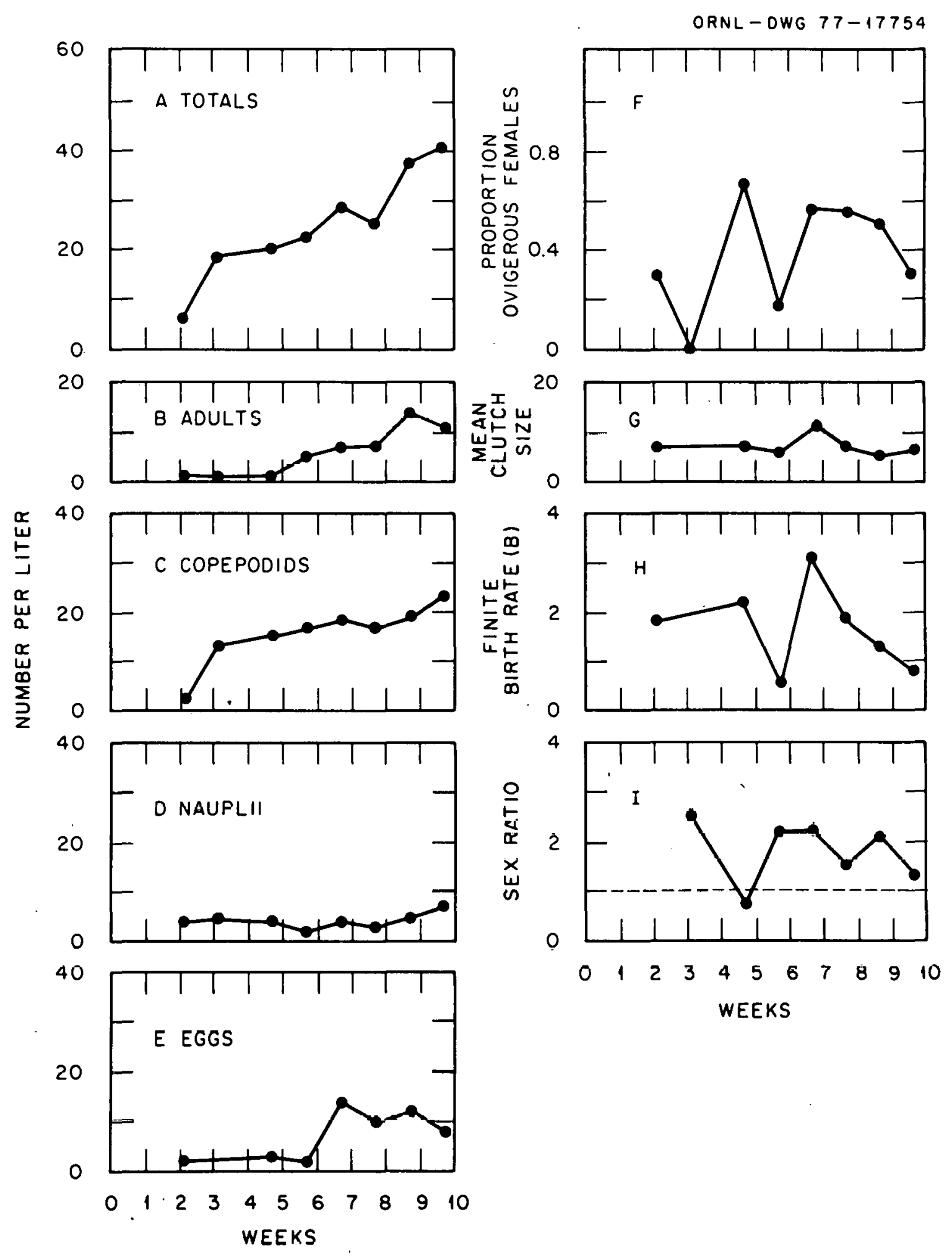

Fig. 2. Population estimates and breeding parameters for aquarium two, monitoring experiment one. 


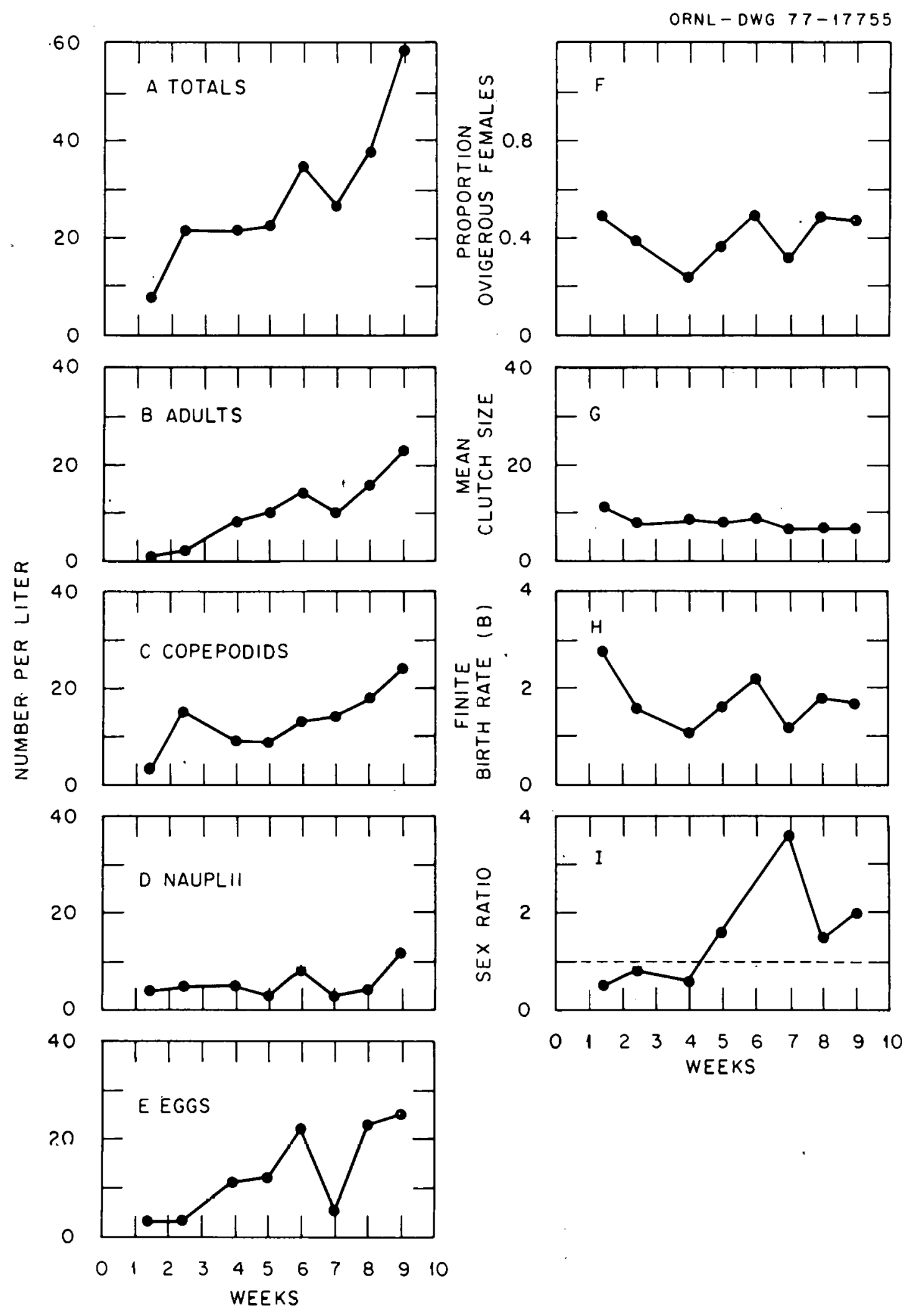

Fig. 3. Population estimates and breeding parameters for aquarium five, monitoring experiment one. 


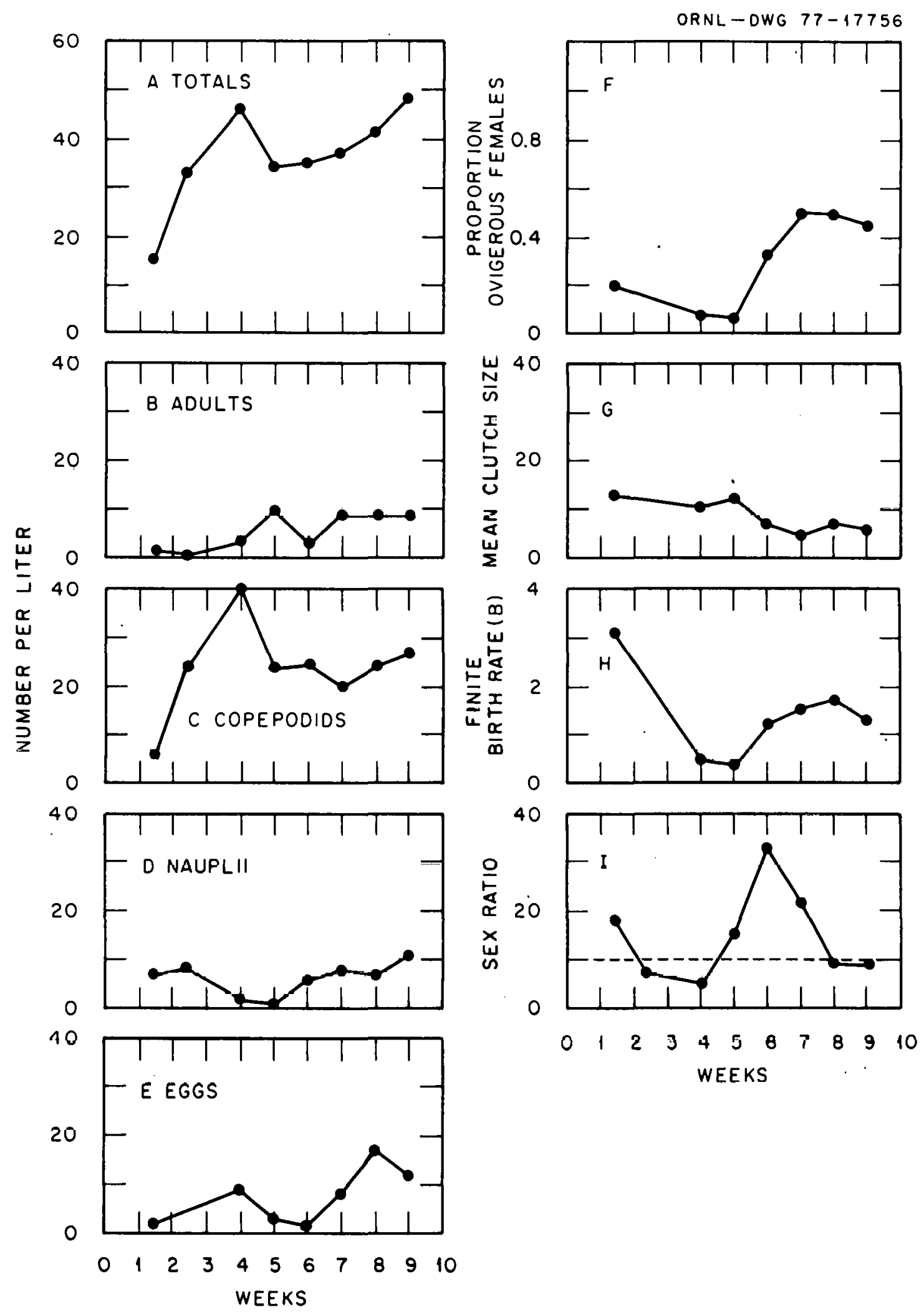

Fig. 4. Population estimates and breeding parameters for aquarium six, monitoring experiment one. 
Figure 5. Population est imates and breeding parameters for aquarium one, monitoring experiment two.

Graph A. Total number of animals per liter

Graph B. Number of adults per liter

Graph C. Number of copepodids per liter

Graph D. Number of nauplii per liter

Graph E. Number of eggs per liter

Graph F. Proportion of ovigerous females

Graph G. Mean number of eggs per clutch

Graph H. Finite birth rate (B)

Graph I. Sex ratio (males/females) 

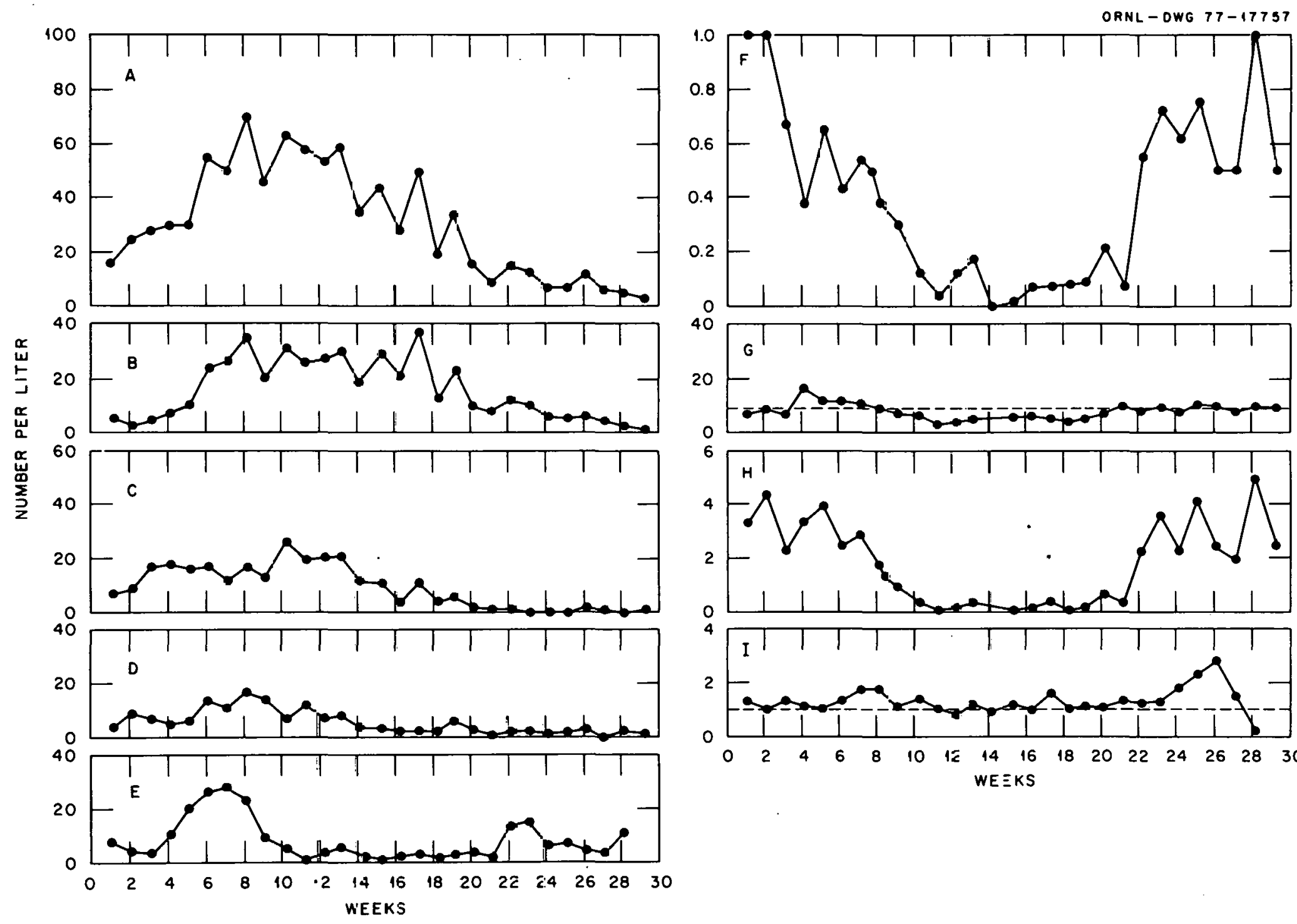

Fig. 5. Populatior estimates and breeding parameters for aquarium one, monitoring experiment two. 
Figure 6. Population estimates and breeding parameters for aquarium two, monitoring experiment two.

Graph A. Total number of animals per liter

Graph B. Number of adults per liter

Graph C. Number of copepodids per liter

Graph D. Number of nauplii per liter

Graph E. Number of eggs per liter

Graph F. Proportion of ovigerous females

Graph $G$. Mean number of eggs per clutch

Graph H. Finite birth rate (B)

Graph I. Sex ratio (males/females) 

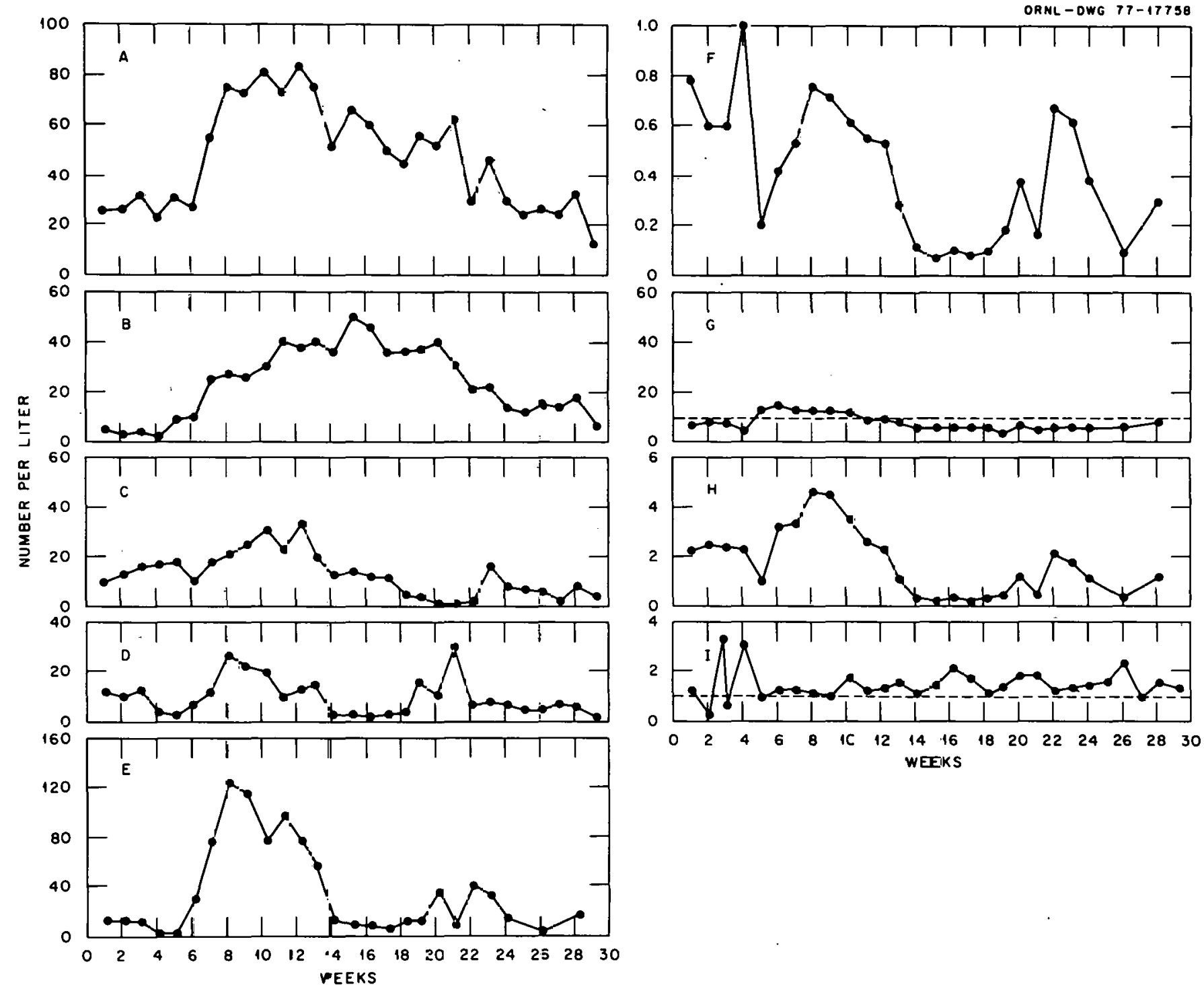

Fig. 6. Population estimates and breeding parameters for aquarium two, monitoring experineרt two. 
Table 1. Percent composition of experimental populations of Diaptomus clavipes, monitoring experiment one

\begin{tabular}{|c|c|c|c|c|}
\hline Day & Adults & Nauplii & Copepodids & Imma tures \\
\hline \multicolumn{5}{|c|}{$-\ldots-$ Aquarium 1---- } \\
\hline $\begin{array}{l}15 \\
22 \\
33 \\
40 \\
47 \\
54 \\
61 \\
68\end{array}$ & $\begin{array}{r}8.4 \\
7.5 \\
21.5 \\
21.8 \\
24.0 \\
30.9 \\
35.7 \\
33.6\end{array}$ & $\begin{array}{r}43.4 \\
29.2 \\
15.5 \\
9.4 \\
15.8 \\
5.9 \\
9.0 \\
15.1\end{array}$ & $\begin{array}{l}48.2 \\
63.2 \\
63.0 \\
68.8 \\
60.2 \\
63.2 \\
55.3 \\
51.3\end{array}$ & $\begin{array}{l}91.6 \\
92.4 \\
78.5 \\
78.2 \\
76.0 \\
69.1 \\
64.3 \\
66.4\end{array}$ \\
\hline \multicolumn{5}{|c|}{---Aquarium 2--.- } \\
\hline $\begin{array}{l}15 \\
22 \\
33 \\
40 \\
47 \\
54 \\
61 \\
68\end{array}$ & $\begin{array}{r}14.2 \\
7.4 \\
5.8 \\
20.4 \\
25.2 \\
25.1 \\
37.0 \\
27.9\end{array}$ & $\begin{array}{r}53.4 \\
26.8 \\
19.4 \\
8.6 \\
12.7 \\
11.9 \\
13.1 \\
16.2\end{array}$ & $\begin{array}{l}32.4 \\
65.8 \\
74.8 \\
71.0 \\
62.1 \\
63.0 \\
49.9 \\
55.5\end{array}$ & $\begin{array}{l}85.8 \\
92.6 \\
94.2 \\
78.6 \\
74.8 \\
74.9 \\
63.0 \\
72.1\end{array}$ \\
\hline \multicolumn{5}{|c|}{---Aquarium 5---- } \\
\hline $\begin{array}{l}10 \\
17 \\
28 \\
35 \\
42 \\
49 \\
56 \\
63\end{array}$ & $\begin{array}{r}10.8 \\
8.2 \\
35.3 \\
46.0 \\
40.0 \\
37.9 \\
41.6 \\
38.5\end{array}$ & $\begin{array}{l}55.5 \\
23.3 \\
24.0 \\
15.5 \\
23.0 \\
10.1 \\
10.9 \\
20.2\end{array}$ & $\begin{array}{l}33.7 \\
68.5 \\
40.7 \\
38.5 \\
37.0 \\
52.0 \\
47.5 \\
41.3\end{array}$ & $\begin{array}{l}89.2 \\
91.8 \\
64.7 \\
54.0 \\
60.0 \\
62.1 \\
58.4 \\
61.5\end{array}$ \\
\hline \multicolumn{5}{|c|}{---Aquarium 6--.- } \\
\hline $\begin{array}{l}10 \\
17 \\
28 \\
35 \\
42 \\
49 \\
56 \\
63\end{array}$ & $\begin{array}{r}16.0 \\
3.4 \\
9.7 \\
27.9 \\
9.2 \\
24.6 \\
22.9 \\
19.7\end{array}$ & $\begin{array}{r}44.6 \\
23.6 \\
3.9 \\
1.3 \\
18.4 \\
20.9 \\
17.8 \\
24.0\end{array}$ & $\begin{array}{l}39.4 \\
73.0 \\
86.4 \\
70.8 \\
72.4 \\
54.5 \\
59.3 \\
56.3\end{array}$ & $\begin{array}{l}84.0 \\
96.9 \\
90.3 \\
72.1 \\
90.8 \\
75.4 \\
77.1 \\
80.3\end{array}$ \\
\hline
\end{tabular}


were dominant during the first weeks, however, the copepodid stages, which were longer in duration, soon predominated. As the copepodid stages matured, there was a gradual increase in the percent of adults. This trend can be more clearly seen in the second monitoring experiment (Table 2). The immature stages were predominant during the first 10 to 11 weeks, however, after this, the adults then became dominant. As the populations declined, there was a gradual shift back to the immature stages during the final weeks of the study.

The two sets of populations exhibited the same general growth patterns and composition during the first nine weeks. The populations in experiment two, however, which were started at a density and feeding regime twice as great as in experiment one, had population sizes that averaged 1.5 times greater than those populations in experiment one.

Sex ratio

The variation in the ratio of adult males to adult females is shown in Figures 1-6 (Graph I). For the greater part of this study, males were more numerous than females (quotient $>1$ ). The sex ratio for the populations in experiment one averaged 1.52, while the average for the populations in experiment two was 1.33. There did not appear to be any association between sex ratio and any of the life stage estimates in the first experiment. In the second experiment, however, there was an association between sex ratio and the estimates for copepodids and adults. When the sex ratio for a sampling period was compared to the est imate of the number of copepodids per liter one week prior to that date, it was apparent that depressions in the number of copepodids led 
Table 2. Percent composition of experimental populations of Diaptomus clavipes, monitoring experiment two

\begin{tabular}{|c|c|c|c|c|c|c|c|c|}
\hline \multirow[b]{2}{*}{ Day } & \multicolumn{4}{|c|}{ Aquarium 1} & \multicolumn{4}{|c|}{ Aquarium 2} \\
\hline & Ajults & Nauplii & Copepodids & Imma tures & Adults & Naupli i & Copepodids & Imma tures \\
\hline 8 & 32.4 & 22.6 & 45.0 & 67.6 & 19.0 & 44.8 & 36.2 & 81.0 \\
\hline 15 & 8.1 & 34.9 & 57.0 & 91.9 & 11.2 & 39.9 & 48.9 & 88.8 \\
\hline 22 & 12.7 & 24.1 & 63.2 & 87.3 & 11.9 & 39.3 & 48.8 & 88.1 \\
\hline 29 & 22.3 & 16.3 & 61.4 & 77.7 & 8.5 & 19.0 & 72.5 & 91.5 \\
\hline 36 & 32.5 & 15.2 & 52.3 & 67.5 & 30.4 & 10.2 & 59.4 & 69.6 \\
\hline 43 & 43.9 & 25.6 & 30.5 & 56.1 & 38.1 & 25.9 & 36.0 & 61.9 \\
\hline 50 & 52.8 & 22.9 & 24.3 & 47.2 & 45.7 & 21.6 & 32.7 & 54.3 \\
\hline 57 & 50.2 & 24.9 & 24.9 & 49.8 & 36.2 & 36.3 & 27.5 & 63.8 \\
\hline 64 & 42.9 & 29.7 & 27.4 & 57.1 & 35.4 & 29.9 & 34.7 & 64.6 \\
\hline 72 & 48.2 & 10.9 & 40.9 & 51.8 & 36.6 & 25.0 & 38.4 & 63.4 \\
\hline 79 & 43.9 & 21.0 & 35.1 & 56.1 & 55.2 & 13.4 & 31.4 & 44.8 \\
\hline 86 & 49.6 & 12.4 & 38.0 & 50.4 & 45.6 & 15.1 & 39.3 & 54.4 \\
\hline 92 & 49.7 & 14.1 & 36.2 & 50.3 & 53.3 & 19.5 & 27.2 & 46.7 \\
\hline 99 & 54.2 & 11.1 & 34.7 & 45.8 & 69.9 & 5.6 & 24.5 & 30.1 \\
\hline 107 & 68.1 & 6.9 & 25.0 & 37.9 & 75.1 & $4 . j$ & 20.8 & 24.9 \\
\hline 114 & 76.6 & 8.0 & 15.4 & 23.4 & 76.8 & 2.9 & 20.3 & 23.2 \\
\hline 121 & 74.7 & 3.8 & 21.5 & 25.3 & 70.6 & 5.3 & $24.1^{\circ}$ & 29.4 \\
\hline 128 & 67.9 & 10.5 & 21.6 & 32.1 & 80.3 & 7.9 & 11.8 & 19.7 \\
\hline 134 & 65.4 & 17.0 & 17.6 & 34.6 & 64.7 & 28.6 & 6.7 & 35.3 \\
\hline 141 & 64.7 & 22.3 & 13.0 & 35.3 & 76.7 & 20.9 & 2.4 & 23.3 \\
\hline 148 & 81.3 & 13.2 & 5.5 & 18.7 & 49.7 & 48.3 & 2.0 & 50.3 \\
\hline 155 & 80.5 & 16.1 & 3.4 & 19.5 & 70.7 & 22.6 & 6.7 & 29.3 \\
\hline 162 & 80.6 & 19.4 & 0.0 & 19.4 & 47.6 & 17.7 & 34.7 & 52.4 \\
\hline 169 & 76.5 & 20.4 & 3.1 & 23.5 & 49.4 & 22.6 & 28.0 & 50.6 \\
\hline 176 & 76.5 & 23.5 & 0.0 & 23.5 & 48.6 & 20.3 & 31.1 & 51.4 \\
\hline 183 & 54.0 & 28.0 & 18.0 & 46.0 & 58.2 & 17.6 & 24.2 & 41.8 \\
\hline 190 & 77.5 & 7.8 & 14.7 & 22.5 & 59.7 & 29.8 & 10.5 & 40.3 \\
\hline 197 & 49.9 & 41.5 & 8.6 & 50.1 & & 18.2 & 24.7 & 42.9 \\
\hline \multirow[t]{2}{*}{205} & 28.3 & 43.4 & 28.3 & 71.7 & 49.8 & 17.9 & 32.3 & 50.2 \\
\hline & & & & & & & & \\
\hline
\end{tabular}


to numerical dominance of males. When the sex ratio was compared to the number of adults per liter for any one date, the population peaks and depressions coincided with those of the sex ratio quotient during periods of maximum density. During periods of low densities, males were predominant.

\section{Egg production}

The temporal variations in egg stock (number of eggs per liter), proportion of ovigerous females, mean clutch size, and finite birth rate (B), are shown in Figures 1-6 (Graphs E-H). The maximum in egg stock occurred during the period of initial rapid growth (Figures 5-6, Graph E). There was a lag of about 4 to 5 weeks before this increase which coincided with the maturation of the initial generation. A second peak in egg stock occurred near the end of the study when the populations as a whole were declining. There was high mortality during this period since no subsequent peaks in the nauplier or copepodid stages occurred.

The proportion of ovigerous females present in the populations shows a close association with the egg stock (Figures 5-6, Graph F). There was a high proportion during the period of initial growth, almost no ovigerous females after the initial peak in population size, and then an increase when the populations were at low densities.

The number of eggs per clutch varied from 2 to 27 during the study period. The largest clutches were produced during the initial weeks when the population densities were low, as the density increased, clutch size decreased. This can be more clearly seen in Figures 5-6 (Graph G) where the broken line represents the grand mean $(\bar{x}=9.09, S E=0.26)$. 
The greatest departures above this line occurred during the first 10 weeks after an initial lag of 4 to 5 weeks which, again, coincided with the maturation of the initial generation.

The finite birth rate (B) averaged 1.82 and ranged from 0.06 to 5.00 during the course of the study (Figures 5-6, Graph H). The same trend is shown in this graph as was previously described for the egg stock, proportion of ovigerous females, and mean clutch size. Changes in the finite birth rate appear to be more strongly influenced by the proportion of ovigerous females, rather than mean clutch size.

\section{Supp lementary experiments}

Supplementary experiments were conducted in an attempt to determine why there was no repopulation of the aquaria in monitoring experiment two after the initial decline in their populations. In the first supplementary experiment which compared the number of eggs produced per clutch in spring water and aquarium water, an analysis of variance revealed a significant difference $(P<0.05)$ among the water types (Table 3). The a posteriori comparison of the means revealed that those clutches produced in aquarium water were significantly larger than those produced in spring water (Table 4). The rate of clutch production was not significantly different among the water types.

In the second experiment, egg production was compared in aquarium water and spring water receiving two different feeding regimes. In one beaker, a female produced two sacs with egg material but no discernible eggs and these were not included in the analysis. An analysis of variance showed no significant differences in clutch size among either the 
Table 3. Anova calculations showing the differences among the number of eggs per clutch produced in spring water and aquarium water

\begin{tabular}{|c|c|c|c|c|c|}
\hline Source of variation & $d f$ & Sum of squares & Mean squares & F-value & $P R>F$ \\
\hline Among water types & 2 & $\epsilon .842 \varsigma^{\mathrm{a}}$ & 3.4215 & 5.00 & 0.0106 \\
\hline Error & 49 & 33.5407 & $0 . € .845$ & & \\
\hline Tota 1 & 57 & 40.3836 & & & \\
\hline
\end{tabular}

${ }^{3}$ Square root transformation used in calculating analysis of variance. 
Table 4. A posteriori comparison of the mean number of eggs per clutch produced in spring water and aquarium water using Duncan's new multiple range test

\begin{tabular}{lccr}
\hline Water types & Aquarium 1 & Aquarium 2 & Spring \\
Sample size & 18 & 12 & 22 \\
Means $^{\mathrm{a}, \mathrm{b}}$ & 18.67 & 17.73 & 12.58 \\
& - & & \\
& & &
\end{tabular}

${ }^{a}$ Means enclosed by the range of any one line are not significantly different at the 0.051 evel.

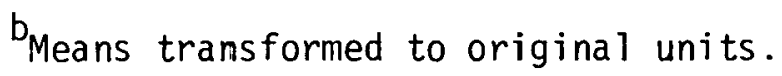


water types or food levels, however, there was a significant difference in the rate of clutch production among the water types (Table 5). The a posteriori comparison, again, showed that more clutches were produced in aquarium water than in spring water (Table 6). Food level had no significant effect on clutch production, however, females which received food in a concentration of $2.5 \mathrm{~g} /$ liter produced clutches at a slightly higher rate than at a food level of $40 \mathrm{~g} /$ liter concentration.

In the final experiment, ovigerous females were removed from the aquaria populations and maintained for 21 days under optimum feeding conditions. The data on clutch size were subdivided into four time intervals and compared using an analys is of variance which was highly significant $(P<0.0001)$ (Table 7$)$. The a posteriori comparison showed that the mean for day 0 , which was the lowest, was significantly different from all the other means (Table 8). The mean for the first week was the next lowest and was significantly smaller than the mean for the second week which was the largest. In the finai week, there was a slight decline in egg production, but it was not significantly different from either the first or second week.

\section{Static System}

In the initial experiment, in which the animals received no food for 14 days, a total of 20 clutches were produced among the three density levels. Of this total, 16 were produced during the first two days and only four during the remaining 12 days. The mean clutch size for the first two days calculated over the three density levels was $24.19 \pm$ 1.75 eggs while the mean for the other four clutches was $7.50 \pm 1.66$ 
Table 5. Anova calculations showing the differences among the number of clutches produced per female in aquarium water and spring water at two different food levels

\begin{tabular}{lcccrr}
\hline Source of variation & $d f$ & Sum of squares & Mean squares & F-value & PR $>F$ \\
\hline Among water types & 1 & 0.06193738 & 0.06193738 & 11.08 & 0.0046 \\
Among food levels & 1 & 0.00697942 & 0.00697942 & 1.25 & 0.2814 \\
Water x food & 1 & 0.00002582 & 0.00002582 & 0.00 & 0.9467 \\
Error & 15 & 0.08385143 & 0.00559010 & & \\
Total & 18 & 0.15279405 & & & \\
\end{tabular}


Table 6. A posteriori comparison of the mean number of c utches aroduced per female in aquarium water and spring water at two different food levels using Dunzan's new multiple range test

\begin{tabular}{|c|c|c|c|c|}
\hline Water types & Aquarium & Aquarium & Spring & Spring \\
\hline Food levels & $2.5 \mathrm{~g} / 1 \mathrm{iter}$ & $40 \mathrm{~g} / 1$ iter & $2.5 \mathrm{~g} / 1 \mathrm{iter}$ & $40 \mathrm{~g} / 1$ iter \\
\hline Sample size & $\angle$ & 5 & 5 & 5 \\
\hline Means $^{a, b}$ & 0.3742 & 0.3333 & 0.2553 & 0.2190 \\
\hline
\end{tabular}

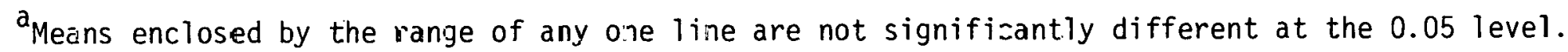

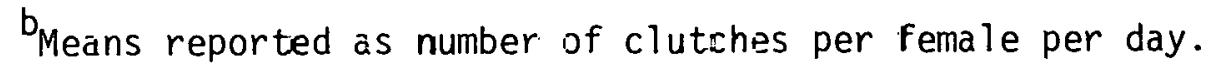


Table 7. Anova calculations showing the differences among the number of eggs per clutch at different time intervals produced by females taken from aquarium water

\begin{tabular}{|c|c|c|c|c|c|}
\hline Source of variation & $d f$ & Sum of squares & Mean squares & F-value & $P R>F$ \\
\hline Among time intervals & 3 & $33.3081^{a}$ & 11.1027 & 11.43 & 0.0001 \\
\hline Error & 66 & 64.0846 & 0.9710 & & \\
\hline Total & 69 & 97.3927 & & & \\
\hline
\end{tabular}

${ }^{a}$ Square roat transformation used in calculating analysis of variance. 
Table 8. A posteniori comparison of the nean number of eggs per clutch produced at different time intervals by females taken from aquarium water using Duncan's new multiple range test

\begin{tabular}{|c|c|c|c|c|}
\hline Time interval (dags) & $3-14$ & $15-21$ & $1-7$ & 0 \\
\hline Sample size & 23 & 19 & 18 & 10 \\
\hline Means $^{a, b}$ & 19.97 & 16.21 & 11.57 & 5.83 \\
\hline
\end{tabular}

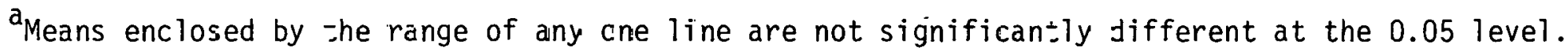

beans transformed to original units. 
eggs. It is clear that the clutches produced during the first two days were indicative of optimum feeding conditions prior to the onset of the experiment. These clutches were also the first produced by the females since they were kept isolated until they matured. These data were not used when the various food and density levels were compared.

The rate of clutch production was determined for each container at the three density and food levels for the three remaining experiments based on the entire data set. No clutches were produced in three containers at the lowest density level, two in a food concentration of 2.5 $\mathrm{g} / \mathrm{liter}$ and the third in a food concentration of $5 \mathrm{~g} / \mathrm{liter}$. An analysis of variance comparing the rate of clutch production among the various food and density levels, excluding these three containers, revealed no significance at the 0.05 level. The mean rate of clutch production along with the reproductive rates for each density level, food level combination are presented in Table 9. Since the egg clutches were removed before they hatched, the reproductive rate was calculated by summing all the eggs produced in any one container and dividing by the total number of days that females were present.

The means for the data compiled for the three density levels at the remaining food levels were tabulated for the number of eggs per clutch, total clutch volume, and individual egg volume (Tables 10-12). The means were calculated over three time intervals.

A two-way analysis of variance was computed for the number of eggs per clutch produced during days 3 to 21 , with the data transformed using the square root transformation. The two fixed factors were density and food level. The data for all containers within a cell were combined so 
Table 9. Mean rate of clutch production and reproductive rates for the static system calculated for each density and food level combination

\begin{tabular}{|c|c|c|c|c|c|c|c|}
\hline \multirow{2}{*}{$\begin{array}{r}\text { Food } \\
\text { level }\end{array}$} & \multirow{2}{*}{$\begin{array}{l}\text { Density } \\
\text { level }\end{array}$} & \multicolumn{3}{|c|}{ Number of clutches per day } & \multicolumn{3}{|c|}{ Number of eggs per day } \\
\hline & & Mean & $S E^{\mathrm{a}}$ & $n$ & Mean & SE & $n$ \\
\hline \multirow{3}{*}{$2.5 \mathrm{~g} / 1 \mathrm{iter}$} & 3 & 0.1970 & 0.0373 & 10 & 3.16 & 0.64 & 10 \\
\hline & 6 & 0.1715 & 0.0584 & 4 & 2.89 & 1.06 & 4 \\
\hline & 12 & 0.7665 & 0.0041 & 2 & 2.53 & 0.15 & 2 \\
\hline \multirow{3}{*}{$5 \mathrm{~g} / 1 \mathrm{iter}$} & 3 & 0.2703 & 0.0458 & 11 & 5.18 & 1.01 & 11 \\
\hline & 6 & 0.1851 & 0.0289 & 4 & 3.47 & 0.56 & 4 \\
\hline & 12 & 0.3236 & 0.0313 & 2 & 6.14 & 0.57 & 2 \\
\hline \multirow{3}{*}{$10 \mathrm{~g} / 1 \mathrm{iter}$} & 3 & 0.2590 & 0.0331 & 12 & 7.43 & 1.09 & 12 \\
\hline & 6 & 0.3318 & 0.0129 & 4 & 9.38 & 0.53 & 4 \\
\hline & 12 & ก..3718 & 0.0041 & 2 & 7.96 & 0.71 & 2 \\
\hline
\end{tabular}

${ }^{\mathrm{A}} \mathrm{SE}=$ Standard error. 
Table 10. Mean number of eggs per clutch produced at three density and food levels in a static system

\begin{tabular}{|c|c|c|c|c|c|}
\hline $\begin{array}{l}\text { Food } \\
\text { level }\end{array}$ & $\begin{array}{c}\text { Density } \\
\text { level }\end{array}$ & Days & $\begin{array}{c}\text { Sample } \\
\text { size }\end{array}$ & Means $^{\mathrm{a}}$ & $\begin{array}{c}\text { Standard } \\
\text { error }\end{array}$ \\
\hline \multirow{4}{*}{$2.5 \mathrm{~g} / 1 \mathrm{iter}$} & 3 & $\begin{array}{l}1-2 \\
3-21 \\
1-21\end{array}$ & $\begin{array}{r}8 \\
27 \\
35\end{array}$ & $\begin{array}{l}20.63 \\
14.93 \\
16.23\end{array}$ & $\begin{array}{l}3.14 \\
1.30 \\
1.27\end{array}$ \\
\hline & 6 & $\begin{array}{l}1-2 \\
3-21 \\
1-21\end{array}$ & $\begin{array}{r}8 \\
28 \\
36\end{array}$ & $\begin{array}{l}23.38 \\
15.14 \\
16.97\end{array}$ & $\begin{array}{l}2.18 \\
0.96 \\
1.05\end{array}$ \\
\hline & 12 & $\begin{array}{l}1-2 \\
3-21 \\
1-21\end{array}$ & $\begin{array}{r}7 \\
27 \\
34\end{array}$ & $\begin{array}{l}24.14 \\
13.07 \\
15.35\end{array}$ & $\begin{array}{l}5.29 \\
0.84 \\
1.45\end{array}$ \\
\hline & 3 & $\begin{array}{l}1-2 \\
3-21 \\
1-21\end{array}$ & $\begin{array}{r}8 \\
14 \\
22\end{array}$ & $\begin{array}{l}22.38 \\
13.14 \\
16.50\end{array}$ & $\begin{array}{l}2.82 \\
1.54 \\
1.68\end{array}$ \\
\hline \multirow[t]{3}{*}{$5 \mathrm{~g} / 1 \mathrm{iter}$} & 6 & $\begin{array}{l}1-2 \\
3-21 \\
1-21\end{array}$ & $\begin{array}{r}4 \\
26 \\
30\end{array}$ & $\begin{array}{l}27.00 \\
17.38 \\
18.67\end{array}$ & $\begin{array}{l}3.46 \\
1.27 \\
1.32\end{array}$ \\
\hline & 12 & $\begin{array}{l}1-2 \\
3-21 \\
1-21\end{array}$ & $\begin{array}{r}6 \\
24 \\
30\end{array}$ & $\begin{array}{l}25.83 \\
17.29 \\
19.00\end{array}$ & $\begin{array}{l}4.61 \\
0.93 \\
1.30\end{array}$ \\
\hline & 3 & $\begin{array}{l}1-2 \\
3-21 \\
1-21\end{array}$ & $\begin{array}{r}9 \\
34 \\
43\end{array}$ & $\begin{array}{l}33.78 \\
26.62 \\
28.12\end{array}$ & $\begin{array}{l}3.52 \\
1.22 \\
1.27\end{array}$ \\
\hline \multirow[t]{2}{*}{$10 \mathrm{~g} / 1 \mathrm{iter}$} & 6 & $\begin{array}{l}1-2 \\
3-21 \\
1-21\end{array}$ & $\begin{array}{r}8 \\
56 \\
64\end{array}$ & $\begin{array}{l}41.88 \\
26.29 \\
28.23\end{array}$ & $\begin{array}{l}4.30 \\
1.23 \\
1.35\end{array}$ \\
\hline & 12 & $\begin{array}{l}1-2 \\
3-21 \\
1-21\end{array}$ & $\begin{array}{l}10 \\
42 \\
52\end{array}$ & $\begin{array}{l}24.30 \\
26.10 \\
25.75\end{array}$ & $\begin{array}{l}3.00 \\
1.64 \\
1.43\end{array}$ \\
\hline
\end{tabular}

${ }^{a}$ Means calculated in original units. 
Table 11. Means for total clutch volume produced at three density and food levels in a static system

\begin{tabular}{|c|c|c|c|c|c|}
\hline $\begin{array}{l}\text { Food } \\
\text { Tevel }\end{array}$ & $\begin{array}{l}\text { Density } \\
\text { level }\end{array}$ & Days & $\begin{array}{l}\text { Sample } \\
\text { size }\end{array}$ & $\left(\begin{array}{l}\text { Means } \\
\left(\times 10^{-2} \mathrm{~mm}^{3}\right)\end{array}\right.$ & $\begin{array}{l}\text { Standard error } \\
\left(\times 10^{-3} \mathrm{~mm}^{3}\right)\end{array}$ \\
\hline \multirow{4}{*}{$2.5 \mathrm{~g} / \mathrm{liter}$} & 3 & $\begin{array}{l}1-2 \\
3-21 \\
1-21\end{array}$ & $\begin{array}{r}8 \\
25 \\
33\end{array}$ & $\begin{array}{l}3.0549 \\
2.2110 \\
2.4156\end{array}$ & $\begin{array}{l}3.3081 \\
1.7806 \\
1.6705\end{array}$ \\
\hline & 6 & $\begin{array}{l}1-2 \\
3-21 \\
1-21\end{array}$ & $\begin{array}{r}8 \\
28 \\
36\end{array}$ & $\begin{array}{l}3.3371 \\
2.2866 \\
2.5201\end{array}$ & $\begin{array}{l}2.1955 \\
1.2865 \\
1.3237\end{array}$ \\
\hline & 12 & $\begin{array}{l}1-2 \\
3-21 \\
1-21\end{array}$ & $\begin{array}{r}7 \\
26 \\
33\end{array}$ & $\begin{array}{l}3.1037 \\
1.9600 \\
2.2025\end{array}$ & $\begin{array}{l}2.5962 \\
1.2439 \\
1.3795\end{array}$ \\
\hline & 3 & $\begin{array}{l}1-2 \\
3-21 \\
1-21\end{array}$ & $\begin{array}{r}6 \\
9 \\
15\end{array}$ & $\begin{array}{l}3.0178 \\
2.0330 \\
2.4269\end{array}$ & $\begin{array}{l}3.6795 \\
3.3654 \\
2.7350\end{array}$ \\
\hline \multirow[t]{3}{*}{$5 \mathrm{~g} / 1$ iter } & 6 & $\begin{array}{l}1-2 \\
3-21 \\
1-21\end{array}$ & $\begin{array}{r}3 \\
19 \\
22\end{array}$ & $\begin{array}{l}3.3817 \\
2.6616 \\
2.7598\end{array}$ & $\begin{array}{l}2.9458 \\
1.8393 \\
1.7052\end{array}$ \\
\hline & 12 & $\begin{array}{l}1-2 \\
3-21 \\
1-21\end{array}$ & $\begin{array}{r}5 \\
24 \\
29\end{array}$ & $\begin{array}{l}3.4088 \\
2.3552 \\
2.5368\end{array}$ & $\begin{array}{l}2.7008 \\
1.2222 \\
1.3270\end{array}$ \\
\hline & 3 & $\begin{array}{l}1-2 \\
3-21 \\
1-21\end{array}$ & $\begin{array}{r}8 \\
34 \\
42\end{array}$ & $\begin{array}{l}4.3980 \\
3.3871 \\
3.5796\end{array}$ & $\begin{array}{l}6.6049 \\
1.4193 \\
1.7651\end{array}$ \\
\hline \multirow[t]{2}{*}{$10 \mathrm{~g} / 1 \mathrm{iter}$} & 6 & $\begin{array}{l}1-2 \\
3-21 \\
1=21\end{array}$ & $\begin{array}{r}8 \\
55 \\
63\end{array}$ & $\begin{array}{l}4.8869 \\
3.2421 \\
3.4509\end{array}$ & $\begin{array}{l}6.1163 \\
1.3671 \\
1.5625\end{array}$ \\
\hline & 12 & $\begin{array}{l}1-2 \\
3-21 \\
1-21\end{array}$ & $\begin{array}{r}9 \\
41 \\
50\end{array}$ & $\begin{array}{l}3.4266 \\
3.0411 \\
3.1105\end{array}$ & $\begin{array}{l}4.8513 \\
1.9075 \\
1.7810\end{array}$ \\
\hline
\end{tabular}


Table 12. Mean egg volumes for clutches produced at three density and food levels in a static system

\begin{tabular}{|c|c|c|c|c|c|}
\hline $\begin{array}{l}\text { Food } \\
\text { level }\end{array}$ & $\begin{array}{l}\text { Density } \\
\text { level }\end{array}$ & Days & $\begin{array}{l}\text { Sample } \\
\text { size }\end{array}$ & $\left(\times \quad \begin{array}{l}\text { Means } \\
\left(0^{-3} \mathrm{~mm}^{3}\right)\end{array}\right.$ & $\begin{array}{l}\text { Standard error } \\
\left(\times 10^{-4} \mathrm{~mm}^{3}\right)\end{array}$ \\
\hline \multirow{4}{*}{$2.5 \mathrm{~g} / 1 \mathrm{iter}$} & 3 & $\begin{array}{l}1-2 \\
3-21 \\
1-21\end{array}$ & $\begin{array}{r}8 \\
25 \\
33\end{array}$ & $\begin{array}{l}1.5454 \\
1.5932 \\
1.5816\end{array}$ & $\begin{array}{l}1.1551 \\
0.7727 \\
0.6413\end{array}$ \\
\hline & 6 & $\begin{array}{l}1-2 \\
3-21 \\
1-21\end{array}$ & $\begin{array}{r}8 \\
28 \\
36\end{array}$ & $\begin{array}{l}1.4566 \\
1.5828 \\
1.5548\end{array}$ & $\begin{array}{l}0.7505 \\
0.7952 \\
0.6421\end{array}$ \\
\hline & 12 & $\begin{array}{l}1-2 \\
3-21 \\
1-21\end{array}$ & $\begin{array}{r}7 \\
26 \\
33\end{array}$ & $\begin{array}{l}1.4557 \\
1.5013 \\
1.4916\end{array}$ & $\begin{array}{l}1.6824 \\
0.4729 \\
0.5013\end{array}$ \\
\hline & 3 & $\begin{array}{l}1-2 \\
3-21 \\
1-21\end{array}$ & $\begin{array}{r}6 \\
9 \\
15\end{array}$ & $\begin{array}{l}1.5007 \\
1.3352 \\
1.4014\end{array}$ & $\begin{array}{l}1.5256 \\
0.4908 \\
0.6797\end{array}$ \\
\hline \multirow[t]{3}{*}{$5 \mathrm{~g} / 1 \mathrm{iter}$} & 6 & $\begin{array}{l}1-2 \\
3-21 \\
1-21\end{array}$ & $\begin{array}{r}3 \\
19 \\
22\end{array}$ & $\begin{array}{l}1.3510 \\
1.4605 \\
1.4455\end{array}$ & $\begin{array}{l}1.8889 \\
0.5768 \\
0.5471\end{array}$ \\
\hline & 12 & $\begin{array}{l}1-2 \\
3-21 \\
1-21\end{array}$ & $\begin{array}{r}5 \\
24 \\
29\end{array}$ & $\begin{array}{l}1.3874 \\
1.3848 \\
1.3853\end{array}$ & $\begin{array}{l}2.0220 \\
0.4703 \\
0.5011\end{array}$ \\
\hline & 3 & $\begin{array}{l}1-2 \\
3-21 \\
1-21\end{array}$ & $\begin{array}{r}8 \\
34 \\
42\end{array}$ & $\begin{array}{l}1.2308 \\
1.3086 \\
1.2938\end{array}$ & $\begin{array}{l}0.8552 \\
0.3308 \\
0.3120\end{array}$ \\
\hline \multirow[t]{2}{*}{$10 \mathrm{~g} / 1 \mathrm{iter}$} & 6 & $\begin{array}{l}1-2 \\
3-21 \\
1-21\end{array}$ & $\begin{array}{r}8 \\
55 \\
63\end{array}$ & $\begin{array}{l}1.1657 \\
1.2600 \\
1.2480\end{array}$ & $\begin{array}{l}0.5720 \\
0.3311 \\
0.2994\end{array}$ \\
\hline & 12 & $\begin{array}{l}1-2 \\
3-21 \\
1-21\end{array}$ & $\begin{array}{r}9 \\
41 \\
50\end{array}$ & $\begin{array}{l}1.4432 \\
1.1689 \\
1.2183\end{array}$ & $\begin{array}{l}0.9457 \\
0.2798 \\
0.3183\end{array}$ \\
\hline
\end{tabular}


no within cell differences could be detected. There was a highly significant difference $(P<0.0001)$ among the various food levels, but no differences among the various density levels or in the interaction term (Table 13).

Table 14 shows the a posteriori comparison of the means for each food and density level combination. The 1 argest means were the three density levels at the highest food level (10 g/liter). There were no significant differences among these means; however this group was significantly different from all the other means.

The analys is of variance testing for differences in total clutch volume among the various food and density levels revealed similar results (Table 15). There was a highly significant difference $(P<0.0001)$ among the food levels but no difference among the density levels or in the interaction term. Table 16 shows the a posterior $i$ comparisons for the mean total clutch volume. Again, the largest means were the three density leveis at the highest food level ( $10 \mathrm{~g} /$ liter). These were ail similar and differed from all other means except for density level six, food level $5 \mathrm{~g} / \mathrm{liter}$, which was similar to the highest density level.

The analysis of variance for the mean individual egg volumes showed a significant difference among the food levels $(P<0.0001)$ and among the density levels $(P<0.05)$ (Table 17$)$. There was no significant interaction. The a posteriori comparisons showed that the 1 argest means were the three density levels at. fnnd leve $12.5 \mathrm{~g} / 1$ iter. These were significantly larger than all other means at food level $10 \mathrm{~g} / \mathrm{liter}$, but similar to density level six, food level $5 \mathrm{~g} / \mathrm{liter}$ (Table 18). The 
Table 13. Anova calculations showing the differences among the number of eggs per clutch produced at three density and food levels in a static system

\begin{tabular}{|c|c|c|c|c|c|}
\hline Source of variation & cf & Sum of squares & Mean squares & F-value & $P R>F$ \\
\hline Among food levels & 2 & $105.0458^{\mathrm{a}}$ & 52.0458 & 83.36 & 0.0001 \\
\hline Among density levels & 2 & 0.4576 & 0.2288 & 0.36 & 0.6959 \\
\hline Food $x$ density & 4 & 4.2248 & 1.0562 & 1.68 & 0.1557 \\
\hline Error & 269 & 169.4976 & 0.6301 & & \\
\hline Total & 277 & 279.2258 & & & \\
\hline
\end{tabular}

${ }^{a}$ Square rcot transformation used in calculating analys is of variance. 
Table 14. A posteriori comparison of the mean number of eggs per clutch produced at three density and food levels using Duncan's new multiple range test

\begin{tabular}{|c|c|c|c|c|c|c|c|c|c|}
\hline Food level & 10 & 10 & 10 & 5 & 5 & 2.5 & 2.5 & 2.5 & 5 \\
\hline Density level. & 3 & 6 & 12 & 12 & 6 & 6 & 3 & 12 & 3 \\
\hline Sample size & 34 & 56 & 42 & 24 & 26 & 23 & 27 & 27 & 14 \\
\hline Means $^{a, b}$ & 26.14 & 25.48 & 25.22 & 17.01 & 16.81 & 17.67 & 14.19 & 12.75 & 12.57 \\
\hline
\end{tabular}

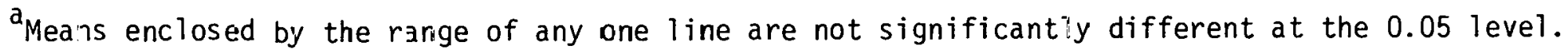

beans transformed to original units. 
Table 15. Anova calculations showing the differences among the total clutch volumes produced at three density and food levels in a static system

\begin{tabular}{lcccrr}
\hline Source of variation & df & Sum of squares & Mean squares & F-value & PR $>F$ \\
\hline Among food levels & 2 & 0.00621551 & 0.00310776 & 37.77 & 0.0001 \\
Among density levels & 2 & 0.00032383 & 0.00016192 & 1.97 & 0.1419 \\
Food x density & 4 & 0.00031551 & 0.00007888 & 0.96 & 0.4308 \\
Error & 252 & 0.02073574 & 0.00008228 & & \\
Total & 260 & 0.02759059 & & & \\
\end{tabular}


Table 16. A posteriori comparison of the mean total clutch volumes producel at three density and food levels using Duncan's new maltiple range test in a static system

\begin{tabular}{|c|c|c|c|c|c|c|c|c|c|}
\hline Food level & 10 & 10 & 10 & 5 & 5 & 2.5 & 2.5 & 5 & 2.5 \\
\hline Density level & 3 & 6 & 12 & 6 & 12 & 6 & 3 & 3 & 12 \\
\hline Sample size & 34 & 55 & 41 & 19 & 24 & 28 & 25 & 9 & 26 \\
\hline Means $^{a, b}$ & 0.0339 & 0.0324 & 0.0304 & 0.0266 & 0.0236 & 0.0229 & 0.0221 & 0.0203 & 0.0196 \\
\hline
\end{tabular}

${ }^{a}$ Means enclosed by the range of any one line are not significantly different at the 0.051 evel.

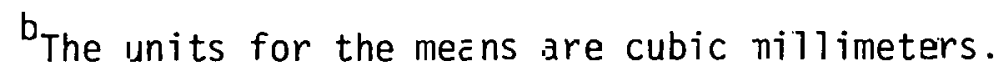


Table 17. Anova calculations showing the differences among the mean egg volumes for each clutch at three density and food levels in a static system

\begin{tabular}{lcccrr}
\hline Source of variation & $\mathrm{df}$ & Sum of squares & Mean squares & F-value & PR $>$ F \\
\hline Among food levels & 2 & 0.00000495 & 0.00000248 & 34.46 & 0.0001. \\
Among density levels & 2 & 0.00000044 & 0.00000022 & 3.06 & 0.0487 \\
Food x density & 4 & 0.00000019 & 0.00000005 & 0.66 & 0.6174 \\
Error & 252 & 0.00001811 & 0.00000007 & & \\
Total & 260 & 0.00002369 & & & \\
\end{tabular}


Table 18. A posteriori comparison of the mean egg volume for the clutches produced at three density and food leveli using Duncan's new multiple range test in a static system

\begin{tabular}{llllllllll}
\hline Food level & 2.5 & 2.5 & 2.5 & 5 & 5 & 5 & 10 & 10 & 10 \\
Density leve1 & 3 & 5 & 12 & 6 & 12 & 3 & .3 & 6 & 12 \\
Sample size & 25 & 28 & 26 & 19 & 24 & 9 & 34 & 55 & 41 \\
Means a,b $^{2}$ & 0.001593 & 0.001583 & $0.0015 c 1$ & 0.0101460 & 0.001385 & 0.001335 & 0.001309 & 0.001260 & 0.001169
\end{tabular}

${ }^{a}$ Means enclosed by the range of any ane line are not significantly different at the 0.05 level.

$b_{\text {Means }}$ reported in cubic millimeters. 
density effect was not evident in the a posteriori comparisons, except that in the highest and lowest food levels, the densities were ranked from low to high with the largest eggs being found at the lower densities.

The mean female metasomal length for each density and food level combination was calculated and is shown in Table 19. There was some evidence that body size and clutch size were positively associated. Simple correlations were computed on the data for days 1 and 2 . These data were used to negate possible confounding effects of temperature, age, and food on egg production since all the females were reared under the same optimum temperature and feeding conditions and were producing their first clutch of eggs. The correlation coefficient for female length and number of eggs per clutch was 0.492 , significant at the 0.0001 level. The correlation coefficient for female length and total clutch volume was 0.552 , also significant at the 0.0001 level.

The condition of the ovaries and the number of spermatophores carried by each female was noted daily. In the first experiment in which the animals were not fed, there was no evidence of egg material in the ovaries or attached spermatophores after day six, and no further egg production. In experiment two, where the animals were not fed for seven days and then fed, a similar trend was noted; however, the day after feeding began, egg material appeared in the ovaries and eggs were produced two days later.

Spermatophores appear to remain attached for less than 24 hours. It also appears that females with one spermatophore attached are more susceptible to subsequent matings. Evidence for this comes from daily 
Table 19. Mean metasomal length of females at three density and food levels in a static system

\begin{tabular}{|c|c|c|c|c|}
\hline rood level & Density lever & Sälinjle si<e & Médiss & Slandard error \\
\hline $2.5 \mathrm{~g} / 1 \mathrm{iter}$ & 3 & 35 & 1.51 & 0.01 \\
\hline $2.5 \mathrm{~g} / 1 \mathrm{iter}$ & 6 & 36 & 1.49 & 0.01 \\
\hline $2.5 \mathrm{~g} / 1 \mathrm{iter}$ & 12 & 34 & 1.47 & 0.01 \\
\hline $5 \mathrm{~g} / 1 \mathrm{iter}$ & 3 & 22 & 1.46 & 0.01 \\
\hline $5 \mathrm{~g} / 1$ iter & 6 & 30 & 1.50 & 0.01 \\
\hline $5 \mathrm{~g} / 1 \mathrm{iter}$ & 12 & 30 & 1.51 & 0.01 \\
\hline iu $\mathrm{g} / \mathrm{T}$ ter & 3 & 43 & 1.61 & 0.01 \\
\hline $10 \mathrm{~g} / 1 \mathrm{iter}$ & 6 & 64 & 1.57 & 0.01 \\
\hline $10 \mathrm{~g} / 1 \mathrm{iter}$ & 12 & 52 & 1.52 & 0.02 \\
\hline
\end{tabular}

dMetasomal lengths are in millimeters. 
observations of individual females. Females that initially had 1 to 3 spermatophores one day had up to 10 the next day. When multiple spermatophores were present, only the one attached to the genital aperture was found discharged. It was also noted that mating may injure the males by breaking off the right antenna at the geniculation or by breaking it off completely, thus functionally removing these individuals from the reproducing population.

There were several cases where sacs were produced with no eggs, or with only a core of egg material and no discernible eggs. It was also noted that approximately 10 percent of all the clutches produced contained from one to three abnormal eggs. These were visibly different from the other eggs by being larger with a core of egg material surrounded by a raised membrane. In some cases, entire clutches were produced with this type of non-viable egg. These phenomena did not appear to be associated with any specific food or density level.

The data compiled in the sex ratio experiment were tested using a two-level nested analys is of variance with the top level, the five sex ratios, and the second level, the five beakers within each sex ratio. The observations were the number of eggs per clutch which were transformed using the square root transformation before calculating the analysis of variance. There was no significant difference at the 0.05 level in egg production among the sex ratios or the females within each sex ratio. A one-way analysis of variance comparing the rate of clutch production among the sex ratios also showed no significance at the 0.05 level. 
Flow-Through System

In the initial experiment in the flow-through system in which the an imals were not fed for 14 days, a total of seven clutches were produced. Since these animals were removed from stock cultures and not fed for two days prior to initiation of the experiment there were no differences in clutch sizes during the 14 day period. The mean clutch size was $8.57 \pm 1.00$ eggs, very similar to the results in the initial static experiment.

The rate of clutch production was determined for each container at the three density and food levels for the three remaining experiments based on the entire data set. No clutches were produced in seven containers at the lowest density level; two containers at a feeding rate of 1.5 hours and five at a rate of six hours. These containers were not included in the analysis. Two clutches of resting eggs were produced during the study at the lowest feeding rate ( 1.5 hours), one at a density of three animals and one at a density of twelve animals. These also were not included in the analysis. The mean rate of clutch production along with the mean reproductive rate are presented in Table 20. An analysis of variance comparing the rate of clutch production at the various food and density levels was not significant at the 0.05 level. It was evident from Table 20 that egg production was reduced in the flow-through system when compared with similar data for the static system (Table 9, p. 50). The mean reproductive rates for the lowest food level ( $2.5 \mathrm{~g} /$ liter) in the static system were greater than the reproductive rates for most of the levels in the flow-through system. 
Table 20. Mean rate of clutch production and reproductive rates for the flow-through system calculated for each density and food level combination

\begin{tabular}{|c|c|c|c|c|c|c|c|}
\hline \multirow{2}{*}{$\begin{array}{l}\text { Food } \\
\text { level }\end{array}$} & \multirow{2}{*}{$\begin{array}{c}\text { Density } \\
\text { level }\end{array}$} & \multicolumn{3}{|c|}{ Number of clutches per day } & \multicolumn{3}{|c|}{ Number of eggs per day } \\
\hline & & Mean & $S E^{a}$ & $n$ & Mean & SE & $n$ \\
\hline & 3 & 0.0789 & 0.0098 & 10 & 1.87 & 0.32 & 10 \\
\hline \multirow[t]{3}{*}{1.5} & 6 & 0.1123 & 0.0263 & 4 & 1.77 & 0.50 & 4 \\
\hline & 12 & 0.1349 & 0.0081 & 2 & 2.74 & 0.31 & 2 \\
\hline & 3 & 0.1262 & 0.0126 & 12 & 2.90 & 0.28 & 12 \\
\hline \multirow[t]{3}{*}{3.0} & 6 & 0.1189 & 0.0241 & 4 & 2.61 & 0.66 & 4 \\
\hline & 12 & 0.0922 & 0.0896 & 2 & 2.48 & 1.45 & 2 \\
\hline & 3 & 0.1444 & 0.0197 & 7 & 2.41 & 0.50 & 7 \\
\hline \multirow[t]{2}{*}{6.0} & 6 & 0.0925 & 0.0086 & 4 & 2.06 & 0.19 & 4 \\
\hline & 12 & 0.0685 & 0.0018 & 2 & 1.74 & 0.22 & 2 \\
\hline
\end{tabular}

$$
{ }^{a} S E=\text { Standard error. }
$$


This was also evident in the data on rate of clutch production. Thus, even though there was a four-fold increase in the duration of feeding, there was very little increase in egg production.

The means for the data compiled for the three density levels at the remaining three food levels were tabulated for number of eggs per clutch, total clutch volume, and individual egg volmes (Tables 21-23). The mean female metasomal lengths were also calculated and are presented in Table 24 .

Two-way analysis of variance was computed for the number of eggs per clutch, total clutch volume, and individual egg volumes per clutch, with the density and food levels, the two fixed factors. The data for all the containers within a cell were combined in the analyses. There were significant differences at the 0.01 level among the number of eggs per clutch and individual egg volumes produced at the various food levels. There were no significant differences among the density levels or in the interaction terms (Tables 25-26). The analys is of variance for total clutch volume indicated no significant differences among the levels at the 0.05 level.

Table 27 shows the a posteriori comparison of the mean number of eggs per clutch for each food and density level combination. The three largest means were the three densities at a feeding rate of six hours. However, only the largest mean was significantly greater than the other food levels. All other means were very similar. The majority of these means were lower than the means for the lowest food level $(2.5 \mathrm{~g} / 1$ iter) in the static system (Table 10, p. 51). 
Table 21. Mean number of eggs per clutch produced at three density and food levels in a flow-through system

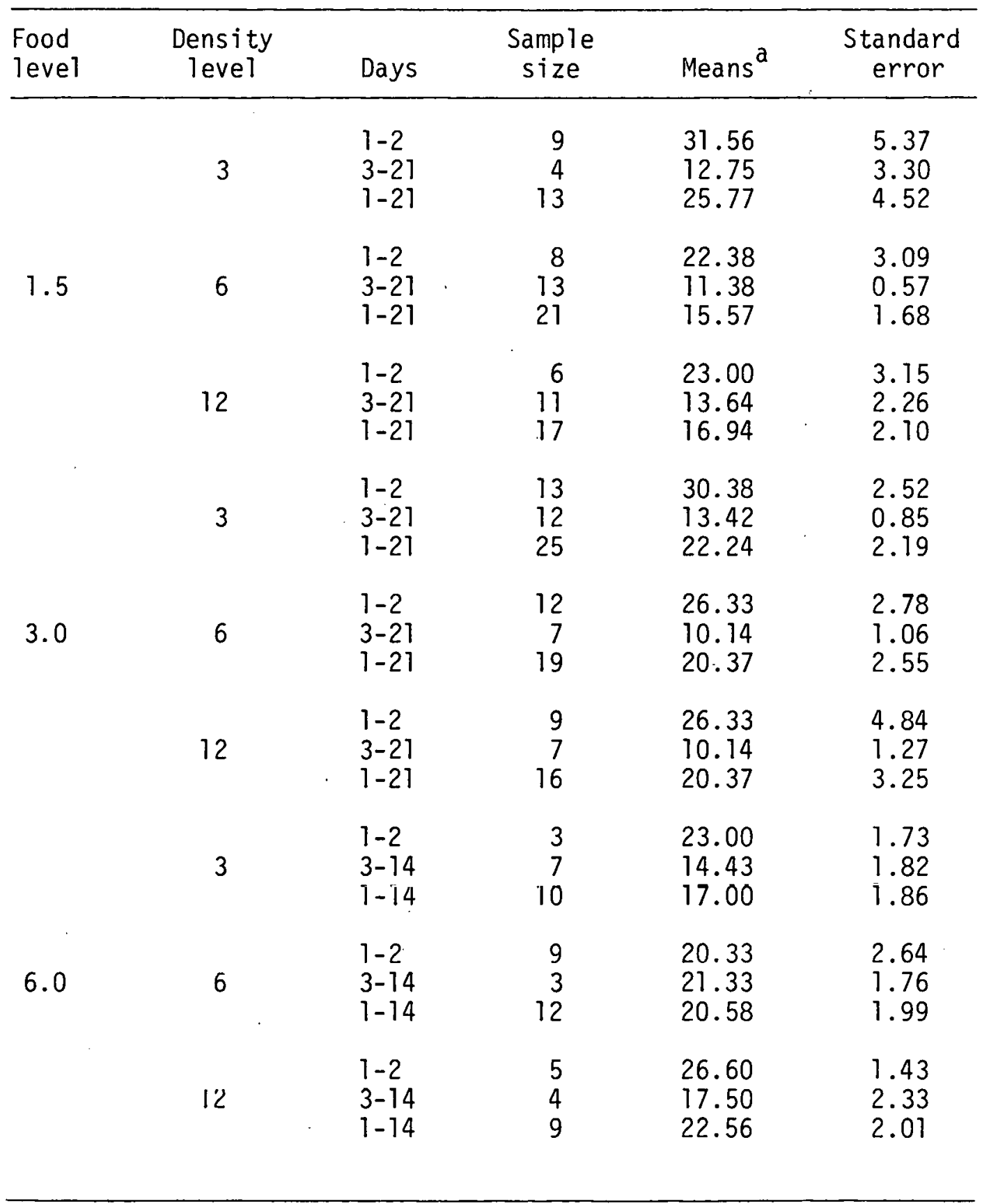

a Means calculated in original units. 
Table 22. Means for total clutch volume produced at three density and food levels in a flow-through system

\begin{tabular}{|c|c|c|c|c|c|}
\hline $\begin{array}{l}\text { Food } \\
\text { level }\end{array}$ & $\begin{array}{l}\text { Density } \\
\text { level }\end{array}$ & Days & $\begin{array}{l}\text { Sample } \\
\text { size }\end{array}$ & $\begin{array}{c}\text { Means } \\
\left(\times 10^{-2} \mathrm{~mm}^{3}\right)\end{array}$ & $\begin{array}{l}\text { Standard error } \\
\left(\times 10^{-3} \mathrm{~mm}^{3}\right)\end{array}$ \\
\hline & 3 & $\begin{array}{l}1-2 \\
3-21 \\
1-21\end{array}$ & $\begin{array}{r}9 \\
4 \\
13\end{array}$ & $\begin{array}{l}3.9069 \\
1.8610 \\
3.2774\end{array}$ & $\begin{array}{l}5.4895 \\
4.1110 \\
4.7580\end{array}$ \\
\hline \multirow[t]{2}{*}{1.5} & 6 & $\begin{array}{l}1-2 \\
3-21 \\
1-21\end{array}$ & $\begin{array}{r}8 \\
12 \\
20\end{array}$ & $\begin{array}{l}2.9786 \\
1.9913 \\
2.3863\end{array}$ & $\begin{array}{l}3.4672 \\
0.8197 \\
1.7990\end{array}$ \\
\hline & 12 & $\begin{array}{l}1-2 \\
3-21 \\
1-21\end{array}$ & $\begin{array}{r}6 \\
11 \\
17\end{array}$ & $\begin{array}{l}2.9062 \\
2.1074 \\
2.3893\end{array}$ & $\begin{array}{l}3.089 \overline{1} \\
2.2751 \\
2.0141\end{array}$ \\
\hline$\circ$ & 3 & $\begin{array}{l}1-2 \\
3-21 \\
1-21\end{array}$ & $\begin{array}{l}13 \\
12 \\
25\end{array}$ & $\begin{array}{l}4.1008 \\
2.4150 \\
3.2916\end{array}$ & $\begin{array}{l}2.6708 \\
1.4197 \\
2.2921\end{array}$ \\
\hline \multirow[t]{3}{*}{3.0} & 6 & $\begin{array}{l}1-2 \\
3-21 \\
1-21\end{array}$ & $\begin{array}{r}12 \\
7 \\
19\end{array}$ & $\begin{array}{l}3.3488 \\
1.7931 \\
2.7757\end{array}$ & $\begin{array}{l}3.1815 \\
1.7676 \\
2.7238\end{array}$ \\
\hline & 12 & $\begin{array}{l}1-2 \\
3-21 \\
1-21\end{array}$ & $\begin{array}{r}9 \\
7 \\
16\end{array}$ & $\begin{array}{l}3.3 \hat{2} 72 \\
1.8213 \\
2.6684\end{array}$ & $\begin{array}{l}4.8350 \\
1.2613 \\
3.3185\end{array}$ \\
\hline & 3 & $\begin{array}{l}1-2 \\
3-14 \\
1-14\end{array}$ & $\begin{array}{l}3 \\
6 \\
9\end{array}$ & $\begin{array}{l}3.2410 \\
2.0558 \\
2.4509\end{array}$ & $\begin{array}{l}8.5085 \\
2.9290 \\
3.5666\end{array}$ \\
\hline \multirow[t]{2}{*}{6.0} & 6 & $\begin{array}{l}1-2 \\
3-14 \\
1-14\end{array}$ & $\begin{array}{r}8 \\
3 \\
11\end{array}$ & $\begin{array}{l}2.7964 \\
2.9113 \\
2.8277\end{array}$ & $\begin{array}{l}2 . \overline{7823} \\
4.4889 \\
2.2509\end{array}$ \\
\hline & 12 & $\begin{array}{l}1-2 \\
3-14 \\
1-14\end{array}$ & $\begin{array}{l}5 \\
4 \\
9\end{array}$ & $\begin{array}{l}3.2672 \\
2.1413 \\
2.7668\end{array}$ & $\begin{array}{l}4.3174 \\
1.9096 \\
3.1142\end{array}$ \\
\hline
\end{tabular}


Table 23. Mean egg volumes for clutches produced at three density and food levels in a flow-through system

\begin{tabular}{|c|c|c|c|c|c|}
\hline $\begin{array}{l}\text { Food } \\
\text { level }\end{array}$ & $\begin{array}{c}\text { Density } \\
\text { level }\end{array}$ & Days & $\begin{array}{l}\text { Sample } \\
\text { size }\end{array}$ & $\begin{array}{c}\text { Means } \\
\left(\times 10^{-3} \mathrm{~mm}^{3}\right)\end{array}$ & $\begin{array}{l}\text { Standard error } \\
\left(\times 10^{-4} \mathrm{~mm}^{3}\right)\end{array}$ \\
\hline \multirow{4}{*}{1.5} & 3 & $\begin{array}{l}1-2 \\
3-21 \\
1-21\end{array}$ & $\begin{array}{r}9 \\
4 \\
13\end{array}$ & $\begin{array}{l}1.2972 \\
1.5035 \\
1.3607\end{array}$ & $\begin{array}{l}0.5637 \\
1.2547 \\
0.5859\end{array}$ \\
\hline & 6 & $\begin{array}{l}1-2 \\
3-21 \\
1-21\end{array}$ & $\begin{array}{r}8 \\
12 \\
20\end{array}$ & $\begin{array}{l}1.3916 \\
1.7166 \\
1.5866\end{array}$ & $\begin{array}{l}1.1335 \\
0.3941 \\
0.6137\end{array}$ \\
\hline & 12 & $\begin{array}{l}1-2 \\
3-21 \\
1-21\end{array}$ & $\begin{array}{l}6 \\
11 \\
17\end{array}$ & $\begin{array}{l}2.6788 \\
1.7004 \\
2.0458\end{array}$ & $\begin{array}{r}12.9472 \\
1.4859 \\
4.5550\end{array}$ \\
\hline & 3 & $\begin{array}{l}1-2 \\
3-21 \\
1-21\end{array}$ & $\begin{array}{l}13 \\
12 \\
25\end{array}$ & $\begin{array}{l}1.4147 \\
1.8145 \\
1.6066\end{array}$ & $\begin{array}{l}0.8990 \\
0.5191 \\
0.6600\end{array}$ \\
\hline \multirow[t]{3}{*}{3.0} & 6 & $\begin{array}{l}1-2 \\
3-21 \\
1-21\end{array}$ & $\begin{array}{r}12 \\
7 \\
19\end{array}$ & $\begin{array}{l}1.3346 \\
1.7927 \\
1.5034\end{array}$ & $\begin{array}{l}0.8297 \\
0.9277 \\
0.8017\end{array}$ \\
\hline & 12 & $\begin{array}{l}1-2 \\
3-21 \\
1-21\end{array}$ & $\begin{array}{r}9 \\
7 \\
16\end{array}$ & $\begin{array}{l}1.3645 \\
1.5569 \\
1.4486\end{array}$ & $\begin{array}{l}1.2628 \\
1.4906 \\
0.9633\end{array}$ \\
\hline & 3 & $\begin{array}{l}1-2 \\
3-14 \\
1-14\end{array}$ & $\begin{array}{l}3 \\
6 \\
9\end{array}$ & $\begin{array}{l}1.3757 \\
1.3848 \\
1.3818\end{array}$ & $\begin{array}{l}2.6127 \\
1.3957 \\
1.1750\end{array}$ \\
\hline \multirow[t]{2}{*}{6.0} & 6 & $\begin{array}{l}1-2 \\
3-14 \\
1-14\end{array}$ & $\begin{array}{r}8 \\
3 \\
11\end{array}$ & $\begin{array}{l}1.3526 \\
1.3795 \\
1.3599\end{array}$ & $\begin{array}{l}1.2840 \\
2.1443 \\
1.0448\end{array}$ \\
\hline & 12 & $\begin{array}{l}1-2 \\
3-14 \\
1-14\end{array}$ & $\begin{array}{l}5 \\
4 \\
9\end{array}$ & $\begin{array}{l}1.3190 \\
1.2699 \\
1.2972\end{array}$ & $\begin{array}{l}1.5944 \\
1.6935 \\
1.0916\end{array}$ \\
\hline
\end{tabular}


Table 24. Mean metasomal length of females at three density and food levels in a flow-through system

\begin{tabular}{ccccc}
\hline Food level & Density level & Sample size & Means $^{\mathrm{a}}$ & Standard error $^{2}$ \\
\hline 1.5 & 3 & 13 & 1.54 & 0.01 \\
1.5 & 6 & 21 & 1.52 & 0.01 \\
1.5 & 12 & 17 & 1.52 & 0.01 \\
3.0 & 3 & 25 & 1.58 & 0.02 \\
3.0 & 6 & 19 & 1.55 & 0.02 \\
3.0 & 12 & 16 & 1.57 & 0.02 \\
6.0 & 3 & 10 & 1.61 & 0.02 \\
6.0 & 6 & 12 & 1.59 & 0.02 \\
6.0 & 12 & 9 & 1.59 & 0.01 \\
\hline
\end{tabular}

Metasomal lengths are in millimeters. 
Table 25. Anova calculations showing the differences among the number of eggs per clutch produced at three density and food levels in a flow-through system

\begin{tabular}{lcccrr}
\hline Source of variation & df & Sum of squares & Mean squares & F-value & PR $>F$ \\
\hline Among food levels & 2 & $3.7905^{\mathrm{a}}$ & 1.8952 & 5.92 & 0.0045 \\
Among density levels & 2 & 0.3170 & 0.1585 & 0.50 & 0.6118 \\
Food x density & 4 & 2.6456 & 0.6614 & 0.3199 & 2.07 \\
Error & 59 & 18.8747 & & 0.0965 \\
Total & 67 & 25.6278 & & & \\
\end{tabular}

a Square root transformation used in calculating analysis of variance. 
Table 26. Anova calculations showing the differences among the mean egg volumes for each clutch at three density and food levels in a flow-through system

\begin{tabular}{|c|c|c|c|c|c|}
\hline Source of variation & $d f$ & Sum of squares & Mean squares & F-value & $P R>F$ \\
\hline Among food levels & 2 & 0.00000140 & 0.00000070 & 7.04 & 0.0019 \\
\hline Among dersity levels & 2 & 0.00000013 & 0.00000007 & 0.65 & 0.5235 \\
\hline Food $x$ density & 4 & 0.00000037 & 0.00000009 & 0.93 & 0.4522 \\
\hline Error & 57 & 0.00000568 & 0.00000010 & & \\
\hline Total & 55 & 0.00000758 & & & \\
\hline
\end{tabular}


Table 27. A posteriori comparison of the mean number of eggs per clutch produced at three density and food levels in a flow-through system using Duncan's new multiple range test

\begin{tabular}{lccccccccc}
\hline Foad level & 6.0 & 6.0 & 6.0 & 3.0 & 1.5 & 1.5 & 3.0 & 1.5 & 3.0 \\
Density level & 6 & 12 & 3 & 3 & 12 & 3 & 12 & 6 & 6 \\
Sample size. & 3 & 4 & 7 & 12 & 11 & 4 & 7 & 13 & 7 \\
Means $^{\text {a }, \mathrm{b}}$ & 21.26 & 17.28 & 14.11 & 13.27 & 12.93 & 12.17 & 12.09 & 11.30 & 9.97 \\
& & & & & & & & & \\
\end{tabular}

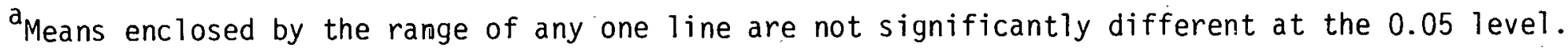

beans transformed to original units. 
The a posteriori comparisons for the mean egg volumes are shown in Table 28. The highest feeding rate (six hours) which had the largest clutches also had the smallest eggs. Most of the egg volumes were very large; even larger than the egg volumes for the lowest food level in the static experiments (Table 12, p. 53). Only the three densities at the highest feeding rate (six hours) were smaller.

\section{Supplementary experiments}

In comparing the data on clutch size for the static and fluwthrough system, it was evident that egg production. in the flow-through system was reduced. Three factors in the flow-through system which differed from the static system were light intensity, flow of water, and administration of food. These variables were analyzed in two separate experiments. In the first experiment, egg production was compared in containers that were subjected to two different light intensities and flow rates for 14 days. An analys is of variance showed no significant differences in egg production amirig the various levels. The animals were then removed from the flow-through system and placed in upliilium feeding conditions for an additional 14 days. The mean clutch sizes for these sets of data are shown in Table 29. It is evident that the stress imposed up on lhe dii imals was relieved when they were removed from the flow-through system and placed under optimum feeding conditions.

The second experiment compared egg production in spring and sterile. water receiving sterile and regular trout chow solution. Analys is of variance was calculated for the number of eggs per clutch and the rate of clutch production, and both showed significant differences among the 
Table 28. A posteriori comparison of the mean egg volumes for clutches produced at three density and food levels in a flow-through system using Duncan's new multiple range test

\begin{tabular}{lccccccccc}
\hline Food Teve & 3.0 & 3.0 & 1.5 & 1.5 & 3.0 & 1.5 & 6.0 & 6.0 & 6.0 \\
Density level & 3 & 6 & 6 & 12 & 12 & 3 & 3. & 6 & 12 \\
Sample size & 12 & $?$ & 12 & 11 & 7 & 4 & 6 & 3 & 4 \\
Means $^{a, b}$ & 0.001814 & $0.00: 793$ & 0.001717 & 0.001700 & 0.001557 & 0.001503 & 0.001385 & 0.001379 & 0.001270
\end{tabular}

${ }^{a}$ Means enclosed by the range of any one line are not significantly different at the 0.05 level.

$b_{\text {Means }}$ reported in cubic millimeters. 
Table 29. Mean number of eggs per clutch for females in two different lighting regimes and rates of water flow

Uays Mcan Standard error Sample size

----Ambient light. and flow-----

$\begin{array}{crcr}1-2 & 21.33 & 1.80 & 6 \\ 3-14 & 6.00 & - & 1 \\ 15-28 & 24.40 & 0.22 & 10\end{array}$

---Ambient light and reduced flow-..--

$\begin{array}{rrrr}1-2 & 26.00 & 1.94 & 5 \\ 3-14 & 19.67 & 1.76 & 3 \\ 15-28 & 29.18 & 4.68 & 11\end{array}$

-.--Increased light and ambient flow-----

$\begin{array}{cccr}1-2 & 25.05 & 7.90 & 6 \\ 3-14 & 11.00 & - & 2 \\ 15-28 & 26.45 & 3.33 & 20\end{array}$

----Increased light and reduced flow--.--

$\begin{array}{rrrr}1-2 & 18.80 & 3.97 & 5 \\ 3-14 & 14.80 & 1.77 & 5 \\ 15-28 & 24.43 & 3.25 & 14\end{array}$


water types (Tables 30-31). The a posteriori comparison of the mean number of eggs per clutch showed that the largest clutches were produced in spring water (Table 32). The clutches in the spring water receiving the regular trout chow solution were significantly larger than in the sterile water fed the regular trout chow. The large clutches produced in the sterile water, sterile food containers, may have been due to the contamination of the water with viable algae brought in when dead animals were replaced.

The a posteriori comparisons for mean rate of clutch production clearly shows that more clutches were produced in spring water than in sterile water (Table 33). It is probable from the results obtained in the supplementary experiments that the stress imposed upon the animals was one of food shortage which resulted in small clutches with very large eggs. The copepods do not appear to subsist on the trout chow solution itself, but rather on the build-up in food organisms such as protozoans whose populations were enhanced by the addition of the trout chow. In the flow-through system, there was no chance for build-up in protozoan populations, thus a food shortage existed. The reduction in egg production was not a permanent one, however, since stressed females were producing maximally within two weeks when placed in optimum feeding conditions. 
Table 30. Anova calculations showing the differences among the number of eggs per clutch produced in sterile water and spring water each receiving two different types of food

\begin{tabular}{|c|c|c|c|c|c|}
\hline Source of variation & $d f$ & Sum of squares & Mear squares & F-value & $P R>F$ \\
\hline Among water types & 1 & $10.2085^{a}$ & 10.2085 & 7.37 & 0.0090 \\
\hline Among food types & 1 & 0.3492 & 0.3492 & 0.25 & 0.6176 \\
\hline Water $x$ food & 1 & 3.7592 & 3.7592 & 2.72 & 0.1054 \\
\hline Error & 52 & 71.9992 & 1.3846 & & \\
\hline Total & 55 & 86.3161 & & & \\
\hline
\end{tabular}

${ }^{a}$ Square root transformation used in calculating analysis of variance. 
Table 31. Anova calculations showing the differences among the number of clutches produced per female in sterile water and spring water each receiving two different types of food

\begin{tabular}{|c|c|c|c|c|c|}
\hline Source of variation & df & Sum of squares & Mean squares & F-value & $P R>F$ \\
\hline Among water types & 1 & 0.11797368 & 0.11791813 & 34.35 & 0.0001 \\
\hline Among food types & 1 & 0.00943791 & 0.00943791 & 2.75 & 0.1181 \\
\hline Water $x$ food & 1 & 0.01061765 & 0.01061765 & 3.09 & 0.0990 \\
\hline Error & 15 & 0.05150000 & 0.00343333 & & \\
\hline Total & 18 & 0.18947368 & & & . \\
\hline
\end{tabular}


Table 32. A posteriori comparison of the mean number of eggs per clutch produced in sterile water and spring water each receiving two different types of food using Duncan's new multiple range test

\begin{tabular}{lcccr}
\hline Water types & Soring & Spring & Sterile & Sterile \\
Food types & Regular & Sterile & Sterile & Regular \\
Sample size & 21 & 13 & 11 & 11 \\
Means ${ }^{a, b}$ & 25.78 & 20.07 & 17.75 & 13.96 \\
& & & \\
\hline
\end{tabular}

a Means enclosed by the range of any one line are not significantly different at the 0.051 evel.

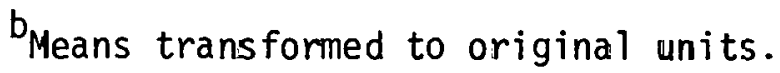


Table 33. A posteriori comparison of the mean number of clutches produced per female in sterile water and spring water each receiving two different types of food using Duncan's new multiple range test

\begin{tabular}{lcccr}
\hline Water types & Spring & Spring & Sterile & Sterile \\
Food types & Regular & Sterile & Regular & Sterile \\
Sample size & 5 & 4 & 5 & 5 \\
Means ${ }^{a, b}$ & 0.4200 & 0.3250 & 0.2200 & 0.2200 \\
& & & \\
\hline
\end{tabular}

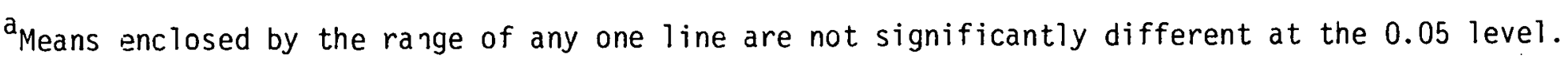

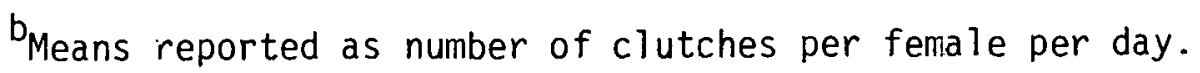


CHAPTER IV

DISCUSSION

Population Studies

Analyses of the data accumulated during these studies revealed that population density, to some degree, affected egg production. This effect was indirect, however, related possibly to competition for food. The quantity of food administered to the aquaria during each experiment was kept constant throughout the experiment. Thus, as population density increased, the quantity of food per individual decreased, resulting in lower egg production. As the populations declined, competition for food decreased and egg production increased.

In monitoring experiment one, the initial densities were two adults per liter and they received $3 \mathrm{ml}$ of food solution, twice weekly. In monitoring experiment two, the initial densities and quantity of food were doubied. The population sizes in the two experiments were compared during the first nine weeks while they were still rapidly growing and were found to be 50 percent greater in experiment two. The mean number of eggs per clutch and the proportion of ovigerous females were also computed and found to be 60 percent higher in experiment two.

In experiment two, the largest egg stock (number of eggs per liter) occurred during weeks 4 to 12 , after an initial lag of four weeks (Figures 5-6, Graph E., p. 33-36). This coincided with the initial maturation of copepods in the aquaria. The largest clutches and the highest proportion of ovigerous females were also associated with these 
young adult populations (Figures 5-6, Graphs F-G, p. 33-36). After this period, although the number of adults continued to increase, egg production decreased precipitously due to a reduction in both clutch size per female and proportion of ovigerous females in the population. Ravera (1955) noted that adult populations of copepods could not be considered as simple numerical quantities, but as biological entities which undergo periods of immaturity, youth, and age. Accordingly, the same number of adults at different time periods does not mean the same reproductive capacity. Robertson et al. (1974), however, found that well-fed Diaptomus clavipes showed no decline in egg production as they grew older. This suggests that egg production was not strongly affected by the aging adult copepods, but by a reduction in the amount of available food due to increased density.

This can be more clearly seen by examining the relationship between the finite birth rate (B) (Figures 5-6, Graph H, p. 33-36) and adult density (Figures 5-6, Graph B., p. 33-36). During the initial period of low density, the birth rate was high; as adult density increased, birth rate decreased to near zero values. During the decline in the adult populations the birth rate again increased: Analyses of the two factors which could affect the finite birth rate (number of eggs per clutch and proportion of ovigerous females) revealed that the proportion of ovigerous females was most important. This factor appeared to be more sensitive to changes in the available food supply. During the period of population decline, a relaxation in competition for food occurred resulting in a rapid increase in the number of ovigerous females in the population although most were carrying small clutches of eggs. During 
the following weeks, a gradual increase in mean clutch size occurred. Gehrs (1972) found that in a natural population of Diaptomus clavipes, the number of eggs per clutch was the main factor affecting specific birth rate $\left(m_{x}\right)$. The proportion of ovigerous females was greater than 0.5 during most of the study indicating that severe food stress was not a factor.

Food stress has also been shown to affect other aspects of life history in both cladocerans and copepods. Coker (1934) cited experiments that showed a prolonging of development in Cyclops vernalis to four to six times the "normal" rate by starving the animals. Ingle et a). (1937) found that Daphnia longispina maintained at $25^{\circ} \mathrm{C}$ and fed a manure infusion which had been diluted by a factor of 36 , lived considerably longer than animals fed the undiluted medium, although the ir reproductive capacity was severely reduced. MacArthur and Baillie (1929, 1929a) suggested that mean longevity in Daphnia magna was an inverse function of the metabolic rate, and metabolic rate as indicated by the rate of heart beat was positively related to temperature and inversely proportional to population density in the range of 1 to. 25 animals $/ \mathrm{cm}^{3}$. They implied that the reduced metabolic rate evinced by crowding may exert the same effect as a metabolism lowered by decreasing the temperature. Comita (1968) found that in several species of Diaptomus respiration was 60 percent lower in unfed individuals which led to a survival time 2.2 times longer than well-fed animals. Thus, starvation of animals can affect the population by depressing egg production and by increasing the duration of the immature and adult stages. 
The supplementary experiments showed that females in aquarium water produced larger clutches than females in spring water under the same conditions (Table 4, p. 43), however, females removed from the aquaria after the study were carrying small clutches indicative of a food stress which was relieved when placed under optimum feeding conditions (Table 8, p. 48). It is possible that bacteria and protozoans whose populations were enhanced during the course of the study may have been competing for food with the copepods in the aquaria, thus imposing a food stress even though the copepod populations were low. It is also possible that a build-up of metabolites inhibited egg production, a phenomenon which has been noted in Daphnia populations by Banta and Brown (1929) and Pratt (1943). Although there was an increase in egg production toward the end of the study, there were no subsequent increases in the immature stages. This could also be explained by shortage of food. The quality of the food source may have changed during the study, making it unsuitable for the immature stages, thus increasing mortality. It is also possible that bacteria may infest the slower moving nauplii contributing to the higher death rate. This has also been noted by Pratt (1943) in cultures of Daphnia magna.

The sex ratio quotient showed that males were more numerous during the study, especially during periods of low density (Figures 5-6, Graph I, p. 33-36). Ravera (1955) found that males predominated during periods of high density, whereas females predominated during periods of low density, a characteristic common of copepods which can produce many fertile clutches after one copulation. Heinle (1970) found that in Eurytemora affinis, a calanoid which requires copulation before each 
clutch of eggs, males predominated at low densities, possibly as a means to insure copulation during these periods. He also found that in Acartia tonsa, a calanoid which can produce many fertile clutches after one copulation, as population density increased the proportion of females decreased. He suggested that some homeostatic mechanisms may be at work, and that in Acartia tonsa, a portion of the genetic males became phenotypic females during the course of their growth in response to low population densites; the reverse may be true for Eurytemora affinis. Diaptomus clavipes requires copulation before production of each clutch (Robertson et al., 1974).

Some authors suggested that males mature earlier and have a shorter life span than females and this could account for the variation in sex ratio (Chapman 1969, Gehrs 1972). This is not evident in this study. When the maximums in egg stock which occurred during the seventh and eighth weeks of the study were compared to the sex ratio four weeks later., which would be the expected time of maturation at the prevailing temperature (Gehrs and Robertson 1975) the sex ratio was near unity.

A final possibility to explain the preponderance of males in laboratory studies was proposed by Battaglia (1958, 1959, 1963; cited in Heinle 1970). He found that alterations in sex ratio in marine harpacticoid copepods, Tisbe sp., involved changes in the genetic ratio in response to population density, temperature, and salinity. He suggested that changes in sex ratio were caused by a polygenic effect, with an increase in females when heterozygosity increased and an increase in males with increased homozygosity. Low population densities and subsequent inbreeding in the laboratory lead to increased homozygosity and a 
high proportion of males. Natural populations which are generally outbreeding have a preponderance of females except during periods of low population density. The average sex ratio for the wild population from which this laboratory stock was collected was 1.28 (Gehrs 1972), very similar to the average of 1.33 in this study, thus it is doubtful that the preponderance of males was due strictly to inbreeding in the laboratory.

\section{Static System}

The data collected in these experiments indicate that food supply was a major factor affecting egg production when temperature levels remained constant. As the food supply was increased, egg production increased. The density levels used in these experiments had little effect. Marshall and Orr (1952) found that increasing the concentration of food increased egg production in female Calanus up to a certain level; above this level, no further increase in egg production was noted. Hall (1964) found that the food levels that he used had no effect on rate of clutch production (frequency of molting) but did affect reproduction through the number of eggs per brood in Daphnia galeata mendotae.

There was an obvious positive correlation between number of eggs per clutch and total clutch volume $(r=0.903, P<0.0001)$; however, there were differences in the groupings of the significant means in the a posteriori comparisons (Tables 14 and 16, p. 56 and 58). For example, the mean total clutch volumes for the three density levels at food level $5 \mathrm{~g} /$ liter were all similar, but when the mean number of eggs per clutch 
were compared, the lowest density had a significantly smaller clutch size than the other two densities. The reason for this can be explained by examining the relationship between number of eggs per clutch and individual egg volumes (Tables 10 and 12, p. 51 and 53): the greater the number of eggs, the smaller the individual egg volumes. This phenomenon has been cited in the literature on calanoid copepods by Wesenberg-Lund (1904), Czeczuga (1959, 1960), Comita (1964), and in cladocerans by Agar (1914), Slobodkin (1951), and Green (1954, 1956, 1966). Lack (1954) has also cited numerous other examples of similar relationships between egg number and egg size in both vertebrates and invertebrates.

Thus, copepods may respond to food shortage by decreasing the total number of eggs produced per clutch and by increasing the size of each individual egg. A given food intake by an adult female can be utilized to produce many small eggs or a few large eggs, thus a compromise must have evolved which leads to the largest number of surviving offspring (Lack 1954). This would have adaptive significance if the larger eggs gave rise to larger nauplii. Wesenberg-Lung (1904) believed that the 1 arger eggs hatched out at a later stage than the first. Green (1954) showed that larger eggs gave rise to larger ynung which became maturc after fewer molts. At $22^{\circ} \mathrm{C}$, young of Daphnia magna with an initial length of 0.98 to $1.06 \mathrm{~mm}$. became mature in the fifth instar while those with an initial length of 0.78 to $0.84 \mathrm{~mm}$ became mature in the sixth instar. Hutchinson $(1951,1967)$ suggested that this variation was not merely a passive effect of low food intake and that part of the variation may prove to have some adaptive meaning. 
In the first two experiments, it was shown that under conditions of severe food shortage egg production ceased. This has also been noted in marine calanoid copepods by Marshall and Orr (1952) and McLaren (1966). Females which had been subjected to these conditions had clear ovaries, and no spermatophores were usually found on these females. Katona (1975) found that male Eurytemora affinis copulated on ly with females which were "ripe" (darkened ovaries). Watras (1977) reached similar conclusions in four species of Diaptomus. Thus, under conditions of extreme food shortage, not only does egg production cease, but also possibly mating activity which would reduce the wasting of effort and gametes by males.

Several investigators have suggested that the number of eggs per clutch was a function of the size of the adult female (Ravera and Tonelli 1956, Bayly 1962, Cole 1966, Maly 1973). McLaren (1965) believed that the total clutch volume was correlated with body size since this volume may vary independently of egg number due to differences in individual egg volumes. This was found to be true for the females in this study for both number of eggs per clutch and total clutch volume when the effects of temperature, food, and age were considered constant during days 1 and 2 .

It was not possible to determine if the size of the female contributed to the increased egg production during the course of the study; however, by comparing the mean clutch sizes for days 3 to 21 (Table 10, p. 51) with the mean female metasomal lengths (Table 19, p. 62), there appears to be no relationship. This is especially true of the highest 
food level where the length ranged from 1.52 to $1.61 \mathrm{~mm}$, the mean clutch sizes varied by less than one egg.

Brooks (1946) found that in natural populations of Daphnia retrocurva the smallest adults produced more eggs than the larger ones when the population was starved. Smyly (1968) also found this to be true in Diaptomus gracilis. During the first two experiments where the animals were not fed for varying lengths of time, the smallest individuals produced the only clutches after the initial clutch (experiment one) or the first clutches when they were fed (experiment two).

The sex ratio experiment indicated that in well-fed copepods, a five-fold increase in the number of males per females made no significant difference in egg production. However, the sex ratio may be important when food supply is reduced. Since males will only mate with ripe females, the probability of a successful mating encounter would be reduced if a high proportion of females were not ripe. A preponderance of males in this situation could increase the number of successful mating encounters.

\section{Flow-Through System}

The results of the flow-through experiments clearly indicate that the animals were stressed by shortage of food which resulted in the production of small clutches of eggs. These smaller clutches also had the largest individual egg volumes, some of which were twice as large as eggs produced under optimum feeding conditions in the static system. These results reinforce the conclusions in the static system section 
that changes in egg volumes were not random processes but were associated with the availability of food.

Two clutches of resting eggs were produced during these experiments. Both were produced during the first feeding experiment (1.5 hours feeding duration). Gehrs and Hardin (1973) found that the production of resting eggs in Diaptomus clavipes was significantly correlated with water temperature and adult density. This does not appear to be the case in this instance since temperature was constant and the clutches were produced at both high (12 animals) and low ( 3 animals) densities. Bunner and Halcrow (1977) found that reducing the amount of available food resulted in the production of sexual eggs in Daphnia magna. This was also reported by Mortimer (1935, cited in Brunner and Halcrow 1977). It is possible that food stress may result in the production of resting eggs, however, more data needs to be collected in this area before any firm conclusions can be drawn.

No clutches were produced in seven of the containers at the lowest density in two of the three feeding experiments. This lack of reproduction could have been caused by the dispersion of scent trails produced by "ripe" females. Flcminger (1967) cited evidence. that planktonic calanoid copepods are likely to utilize chemoreception to ensure mating encounters. In several species of calanoid copepods, distinctive sex specific patterns of swimming have been observed in adult males which appear to represent mating search or ritualistic premating behavior evoked by chemical trail substances, sex pheromones, from recently molted females (Roff 1972, Katona 1973, Kittredge et al. 1974, Griffiths and Frost 1976). Watras (1977) presented evidence for four species of 
Diaptomus which suggested that sex pheromones were produced during the oviducal cycle in order to synchronize mating activity since viable eggs were produced only when the females were mated in the dark phase ( $r$ ipe in Katona's terminology, 1976). He also found that when females were placed together, synchronization of the oviducal cycle occurred. The flow of water may have dispersed the chemical paths, thus reducing the changes of successful mating encounters since males will only copulate with "ripe" females (Katona 1976, Watras 1977).

The feasibility of using this flow-through system to investigate the possible effects of food supply on reproduction in Diaptomus clavipes can be criticized at two levels. First, the food solution which was used not directly utilized by the copepods as indicated by the reduction in both number of eggs per clutch and rate of clutch production in the sterile water (Tables 32-33, p. 80-81). A change in food supply to one which is directly utilized by copepods such as yeast or a unialgal culture should produce better results. Secondly, the flow of water may disrupt possible chemical trails produced by "ripe" females, thus reducing the chances of successful mating encounters at low densities. Some evidence of this can be seen in Table 29 (p. 76) where two flow rates were used. Although the overall relationship was not significant, it is apparent that more clutches with larger mean clutch sizes were produced at both light intensities when the water was connected for only three hours during feeding (reduced flow). Robertson et al. (1974) reported that calanoid copepods can be easily stressed, thus, the flow of water itse if may be enough to reduce egg production without dispersing chemical trails. Further experiments should be done 
subjecting animals to various flow rates under optimum feeding conditions to determine if disruption of chemical trails in a flow-through system is a real possibility. 


\section{CHAPTER V}

\section{SUMMARY AND CONCLUSIONS}

It was found in both the population studies and static experiments that food supply was an important factor determining the proportion of ovigerous females, number of eggs per clutch, and size of individual eggs. As density increased in the population studies, egg production decreased. This probably resulted from competition for food at the higher densities since the densities used in the static experiments had little effect on egg production at any of the feeding levels.

Food shortage also resulted in an increase in the individual egg volumes. During periods of extreme food shortage, not only did egg production cease but also the production of spermatophores by males. When starved females were placed under optimum feeding conditions, they. produced eggs within a few days and were producing maximally within two weeks. Shortage of food may also result in the production of resting eqgs .

Egg production in the flow-through system was reduced, due primarily to food shortage. The trout chow solution was inadequate because it was not directly utilized by the copepods. A food solution such as yeast or algae should produce better results. 


\section{BIBL IOGRAPHY}

Agar, W. E. 1913. Transmission of environmental effects from parent to offspring in Simocephalus vetulus. Phil. Trans. Roy. Soc. Ser. B. $203: 319-350$.

- 1914. Experiments on inheritance in parthenogenesis. Phil. Trans. Roy. Soc. Ser. 8. 205:421-489.

Armitage, K. B., B. Saxena, and E. E. Angino. 1973. Population dynamics of pond zooplankton. I. Diaptomus pallidus Herrick. Hydrobiologia 42:295-333.

Banta, A. M., and L. A. Brown. 1929. Control of sex in Cladocera. II. The unstable nature of the excretory products involved in male production. Physiol. Zool. 2:93-98.

Battaglia, B. 1958. Sex ratio in Tisbe gracilis, a marine copepod. Int. Congr. Zoo l. (London). 15(3), paper 24. - 1959. Facteur thermique et differenciation saisonniere chez un copepode harpacticoide de la Lagune de Venise. Vie Milieu 10:1-13. - 1963. Deviations from panmixia as a consequence of sex determination in the marine copepod, Tisbe reticulata. Int. Conf. Genet. $11(1): 9-26$.

Bayly, I. A. E. 1962. Ecological studies on New Zealand lacustrine zooplankton with special reference to Boeckella propinqua Sars (Copepoda, Calanoida). Austr. J. Mar. Freshw. Res. 13:143-197. Biesinger, K. E., and G. M. Christensen. 1972. Effects of various metals on survival, growth, reproduction, and metabolism of Daphnia magna. J. Fish. Res. Board Can. 29:1691-1700. 
Brooks, J. L. 1946. Cyclomorphos is in Daphnia. I. An analys is of Daphnia retrocurva and Daphnia galeata. Ecol. Monogr. 16:409-447. Bunner, H. C., and K. Halcrow. 1977. Experimental induction of the production of ephippia by Daphnia magna Straus (Cladocera). Crustaceana $32: 77-86$.

Bunting, D. L. 1974. Zooplankton: Thermal regulation and stress. pp. 50-55. In B. G. Gallagher (ed.), Proc. Sym. Energy Production and Thermal Effects. Limnetics, Inc. Milwaukee, September, 1973. Chapman, A. 1969. The bionomics of Diaptomus gracilis Sars (Copepoda, Calanoida) in Loch Lomond, Scotland. J. Anim. Ecol. 38:257-284. Coker, R. E. 1934. Reaction of some freshwater copepods to high temperature. J. Elisha Mitchell Sci. Soc. 50:143-159.

Cole, G. A. 1966. Contrasts among calanoid copepods from permanent and temporary ponds in Arizona. Am. Mid1. Nat. 76:351-368.

Comita, G. W. 1964. The energy budget of Diaptomus siciloides

Lilljeborg. Verh. Internat. Verein. Limno 1. 15:646-653. - 1968. Oxygen consumption in Diaptomus. Limnol. Oceanogr. $13: 51-57$. , and G. C. Anderson. 1959. The seasonal development of a population of Diaptomus ashlandi Marsh, and related phytoplankton cycles in Lake Washington. Limnol. Oceanogr. 4:37-52.

Conover, W. J. 1971. Practical nonparametric statistics. John Wiley and Sons, Inc. New York. $462 \mathrm{pp}$.

Czeczuga, B. 1959. Oviposition in Eudiaptomus gracilis Sars and E. graciloides Lilljeborg (Diaptomidae, Crustacea), in relation to 
season and trophic level of lakes. Bull. Acad. Pol. Sci. C1. II, Ser. Sci. Biol. 7:227-230.

- 1960. Zmi any plodnosci niektorych przedstawicieli zooplanktonu.

I. Crustacea Jezior Rajgradzkich. Polskie Archwm. Hydrobiol.

7:61-91 (English Summary 90-91).

Deevey, G. B. 1960. Relative effects of temperature and food on seasonal variations in length marine copepods in some eastern American and western European waters. Bull. Bingham. Oceanogr. Collect. 17:54-86.

- 1964. Annual variations in length of copepods in the Sargasso sea off Bermuda. J. Mar. Biol. Ass. U. K. 44:589-600. - 1966. Seasonal variations in length of copepods in South Pacific New Zealand waters. Austr. J. Mar. Freshw. Res. $17: 155-168$.

Edmondson, W. T. 1960. Reproductive rates of rotifers in natural populations. Mem. Ist. Ital. Idrobiol. 12:21-77. - 1964. The rate of egg production by rotifers and copepods in natural populations as controlled by food and temperature. Verh. Internat. Verein. Limno 1. 15:673-675.

- 1965. Reproductive rates of planktonic rotifers as related to food and temperature in nature. Ecol. Monogr. 35:61-111. , G. W. Comita, and G. C. Anderson. 1962. Reproductive rates of copepods in nature and its relation to phytoplankton populations. Ecology $43: 625-634$. 
Fleminger, A. 1967. Taxonomy, distribution, and polymorphism in the Labidocera jollae group with remarks on evolution within the group (Copepoda, Calanoida). Proc. U. S. nation. Mus. 120(3567):1-61.

Frank, P. W., C. D. Boll, and R. W. Kelly. 1957. Vital statistics of laboratory cultures of Daphnia pulex DeGeer as related to density. Physiol. Zoo1. 30:287-305.

Gehrs, C. W. 1972. Aspects of the population dynamics of the calanoid copepod, Diaptomus clavipes Schacht. Ph.D. Dissertation. University of Oklahoma. $111 \mathrm{pp}$.

- 1974. Horizontal distribution and abundance of Diaptomus clavipes Schacht in relation to Potamogeton foliosus in a pond and under experimental conditions. Limno 1. Oceanogr. 19:100-104. , and B. D. Hardin. 1974. Production of resting eggs by Diaptomus clavipes Schacht (Copepoda, Calanoida). Am. Midl. Nat. 91:486-488. , and A. Robertson. 1975. Use of 1 ife tables in analyzing the dyanmics of copepod populations. Ecology 56:665-672.

Green, J. 1954. Size and reproduction in Daphnia magna. Proc. Zool. Soc. Lond. $124: 535-545$.

-.. 1956. Growth, size, and reproduction in Daphnią (Crustacea, Cladocera). Proc. 7001. Soc. Lond. 126:173-204. - 1964. Crustacea in Lake Ohrid, with special reference to the ir parāsites and epibionts. Zborn. Rab. Hidrobiol. Zav. Ohrid. $8: 1-11$. - 1966. Seasonal variation in egg production by Cladocera. J. An im. Ecol. 35:77-104. 
Griffiths, A. M., and B. W. Frost. 1976. Chemical communication in the marine planktonic copepods Calanus pacificus and Pseudocalanus sp. Crustaceana 30:1-8.

Hall, D. J. 1964. An experimental approach to the dynamics of a natural population of Daphnia galeata mendotae. Ecology 45:94-112. Hardin, B. D. 1972. Temperature and other factors affecting the reproduction of Diaptomus clavipes (Crustacea, Copepoda, Calanoida).

M. S. Thesis. University of Oklahoma. $75 \mathrm{pp}$.

Hazelwood, D. H., and R. A. Parker. 1961. Population dynamics of some freshwater zooplankton. Ecology $42: 266-274$.

Heinle, D. R. 1970. Population dynamics of exploited cultures of calanoid copepods. Helgolander. wiss. Meeresunters. 20:360-372. Hutchinson, G. E. 1951. Copepodology for the ornithologist. Ecology . $32: 571-577$.

- 1967. A treatise on limnology. II. Introduction to lake biology and the limnoplankton. John Wiley and Sons, Inc., New York. $1115 \mathrm{pp}$.

Ingle, L., T. R. Wood, and A. M. Banta. 1937. A study of longevity, growth, reproduction, and heart rate in Daphnia longispina às influenced by limitations in quantity of food. J. Exp. Zool. $76: 325-352$.

Katona, S. K. 1973. Evidence for sex pheromones in planktonic copepods. Limnol. Oceanogr. 18:574-583. - 1975. Copulation in the copepod, Eurytemora affinis (Poppe 1880). Crustaceana 28:89-95. 
Kittredge, J. S., F. T. Takahashi, J. Lindsey, and R. Lasker. 1974.

Chemical signals in the sea: Marine allelochemics and evolution. Fish. Bull. U. S. 72:1-11.

Lack, D. 1954. The natural regulation of animal numbers. The Clarendon Press, 0xford. 343 pp.

MacArthur, J. W., and W. H. T. Baille. 1929a. Metabolic activity and duration of life. I. Influence of temperature on longevity in Daphnia magna. J. Exp. 2001. 53:221-242.

- 1929b. Metabolic activity and duration of life. II. J. Exp. Zoo 1. 53:243-268.

Maly, E. J. 1973. Density, size, and clutch of two high altitude diaptomid copepods. Limnol. Oceanogr. 18:840-848.

Marshal1, S. M., and A. P. Orr. 1952. On the biology of Calanus finmarchius. VII. Factors affecting egg production. J. Mar. Biol. Ass. U. K. 30:527-547.

- 1955. The biology of a marine copepod. 0liver and Boyd, Edinburgh and London. $187 \mathrm{pp}$.

McLaren, I. A. 1963. Effects of temperature on growth of zooplankton and the adaptive value of vertical migration. J. Fish Res. Board Can. 20:685-727.

- 1965. Some relationships between temperature and egg size, body size, and fecundity of the copepod, rseudocalanus. Limnol.

Oceanogr. 10:528-538.

. 1966. Predicting development rates of copepod eggs. Biol.Bull. Mar. Biol., Woods Hole. 131:457-469. 
Mortimer, C. H. 1935. Untersuchungen uber den Generationswechsel der Cladoceren. Naturwiss. 23:476-480.

Pratt, D. M. 1943. Analys is of population development in Daphnia at different temperatures. Biol. Buss. 85:116-140.

Pyatakov, M. L. 1956. On the seasonal fecundity changes in Cladocera. Z001. Zh. 35:1814-1819.

Ravera, 0. 1955. Seasonal variation of the reproductive rate in pelagic copepods of Lake Maggiore. Verh. Internat. Verein. Limno 1. $12: 436-446$. , and V. Tonolli. 1956. Body size and number of eggs in diaptomids, as related to water renewal in mountain lakes. Limno 1. Oceanogr. 1:118-122.

Robertson, A., C. W. Gehrs, B. D. Hardin, and C. W. Hunt. 1974. Culturing and ecology of Diaptomus clavipes and Cyclops vernalis. Office of Research and Development, U. S. Environmental Protection Agency, Washington, D. C. 227 pp.

Roff, J. C. 1972. Aspects of the reproductive biology of the planktonic copepod, Limnocalanus macrurus (Sars). Crustaceana $22: 150-160$

Siefken, M., and K. B. Armitage. 1968. Seasonal variation in metabolism and organic nutrients in three Diaptomus (Crustacea, Copepoda). Comp. Biochem. Physiol. 24:591-609.

Slobodkin, L. B. 1954. Population dynamics in Daphnia obtusa Kurz. Ecol. Monogr. 24:69-88. 
Smyly, W. J. P. 1968. Number of eggs and body size in the freshwater copepod, Diaptomus gracilis Sars, in the English Lake District. $0 i k$ os 19:323-338.

Snedecor, G. W., and W. G. Cochran. 1967. Statistical methods. Sixth edition. Iowa State University Press, Ames. 593 pp.

Sokal, R. R., and F. J. Rohlf. Biometry. W. H. Freeman and Company, San. Francisco. $776 \mathrm{pp}$.

Watras, C. J. 1977. A reproductive cycle in diaptomid copepods.

Fortieth Annual Meeting of the American Society of Limnology and Oceanography. Michigan State University, East Lansing, June 20-23, 1977 (abstract).

Wesenberg-Lund, C. 1904. Plankton investigations of the Dan ish Lakes. Special Part, Copenhagen. 223 pp.

Whitehouse, J. W., and B. G. Lewis. 1973. The effect of diet and density on development, size, and egg production in Cyclops abyssorum Sars, 1863. Crustaceana 25:227-235.

Wright, J. C. 1965. The population dynamics and production of Daphnia in Canyon Ferry Reservoir, Montana. Limno1. Oceanogr. 10:583-590. 
Table A-1. Analys is of spring water ${ }^{a}$

\begin{tabular}{|c|c|c|}
\hline Determination & Concentration & Method \\
\hline Potassium & $660 \mathrm{ppb}^{\mathrm{b}}$ & Flame emission \\
\hline Sodium & $430 \mathrm{ppb}_{\mathrm{h}}$ & Atomic absorption \\
\hline Calcium & $26.6 \mathrm{ppm}^{\mathrm{D}}$ & Atomic absorption \\
\hline Magnesium & $13.5 \mathrm{ppm}$ & Atomic absorption \\
\hline Strontium & $25 \mathrm{ppb}$ & Flame emission \\
\hline Mangenese & $5 \mathrm{ppb}$ & Atomic absorption \\
\hline Iron (II) & $20 \mathrm{ppb}$ & Atomic äbsororption \\
\hline Iron (tota 1$)$ & $5 \mathrm{ppb}_{\mathrm{h}}$ & Atomic absorption \\
\hline Silver & $300 \mathrm{ppt}^{\mathrm{b}}$ & Spark source mass spec. \\
\hline Gold & $300 \mathrm{ppt}$ & Spark source mass spec. \\
\hline Barium & $81 \mathrm{ppb}$ & Flame emission \\
\hline Cadmi um & $100 \mathrm{ppt}$ & Atomic absorption \\
\hline Chromium & $3 \mathrm{ppb}$ & Atomic absorption \\
\hline Copper & $5 \mathrm{ppb}$ & Atomic absorption \\
\hline Mercury & $50 \pm 10 \mathrm{ppt}$ & Flameless a tomic absorp \\
\hline Lead & $1 \mathrm{ppb}$ & Atomic absorption \\
\hline Zinc & $19 \mathrm{ppb}$ & Atomic absorption \\
\hline $\mathrm{pH}$, from spring & 6.2 & pH meter \\
\hline $\mathrm{pH}$, after aeration & 7.8 & pH meter \\
\hline Total alkalinity & 100 ppm & Volumetric \\
\hline Carbonate & $2 \mathrm{ppm}$ & Volumetric \\
\hline Bicarbonate & $10 \mathrm{ppm}$ & Volumetric \\
\hline Hydroxide & $2 \mathrm{ppm}$ & Volumetric \\
\hline Sulfate & $1 \mathrm{ppm}$ & Spectrophotometric \\
\hline Phosphate & $3 \mathrm{ppb}$ & Spectrophotometric \\
\hline Flourine & $100 \mathrm{ppb}$ & Spectrophotometric \\
\hline Chlorine & $500 \mathrm{ppb}$ & Spectrophotometric \\
\hline DOC, spring water & $0.1-0.4 \mathrm{ppm}$ & Infrared \\
\hline DOC, ORNL distilled water & $0.08 \mathrm{ppm}$ & Infrared \\
\hline Total nitrogen & $100 \mathrm{ppb}$ & Kjeldahl \\
\hline Settleable solids & $200 \mathrm{ppb}$ & Gravimetric \\
\hline Total solids & $126 \mathrm{ppm}$ & Gravimetric \\
\hline Nonvolatile Solids & $57 \mathrm{ppm}$ & Gravimetric \\
\hline
\end{tabular}

${ }^{a}$ Spring water analysis performed by members of the Analytical Chemistry Division, ORNL, November 1972.

$b_{\text {ppt }}=$ parts per trillion, ppb $=$ parts per bilition, ppm $=$ parts per million. 
Table A-2. Guaranteed analysis of Purina trout chow (size four), Ralston Purina Company

-.---Analysis-.---

Crude protein not less than-1

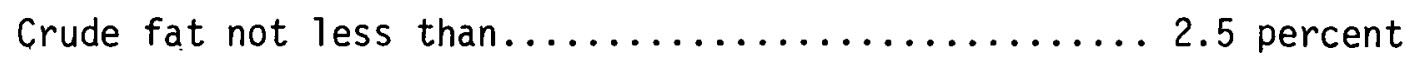

Crude fiber not less than...............

Ash not more than ....................... percent

Added minerals not more than................ percent

-.----Ingredients------

Fish meal, soybean meal, ground wheat, corn gluten meal, brewers' dried yeast, ground yellow corn, wheat middlings, dried blood meal, dried whey, dicaccium phosphate, jodized salt, vitamin A supplement, D activated animal sterol, metadione dimethylpyrimidinol bisulfite (source of vitamin $K$ activity), vitamin $E$ supplement, vitamin $B_{12}$ supplement, ascorbic acid, chloring chloride, folic acid, pyridoxine lyorochloride, thiamin, niacin, calcium pantothenate, riboflavin supplement, copper sulfate, manganous oxide, zinc oxide, calcium carbonate, cobalt carbonate. 
Table A-3. Semi-quantitative spectrographic analysis of Purina trout chow (size four), Ralston Purina Company

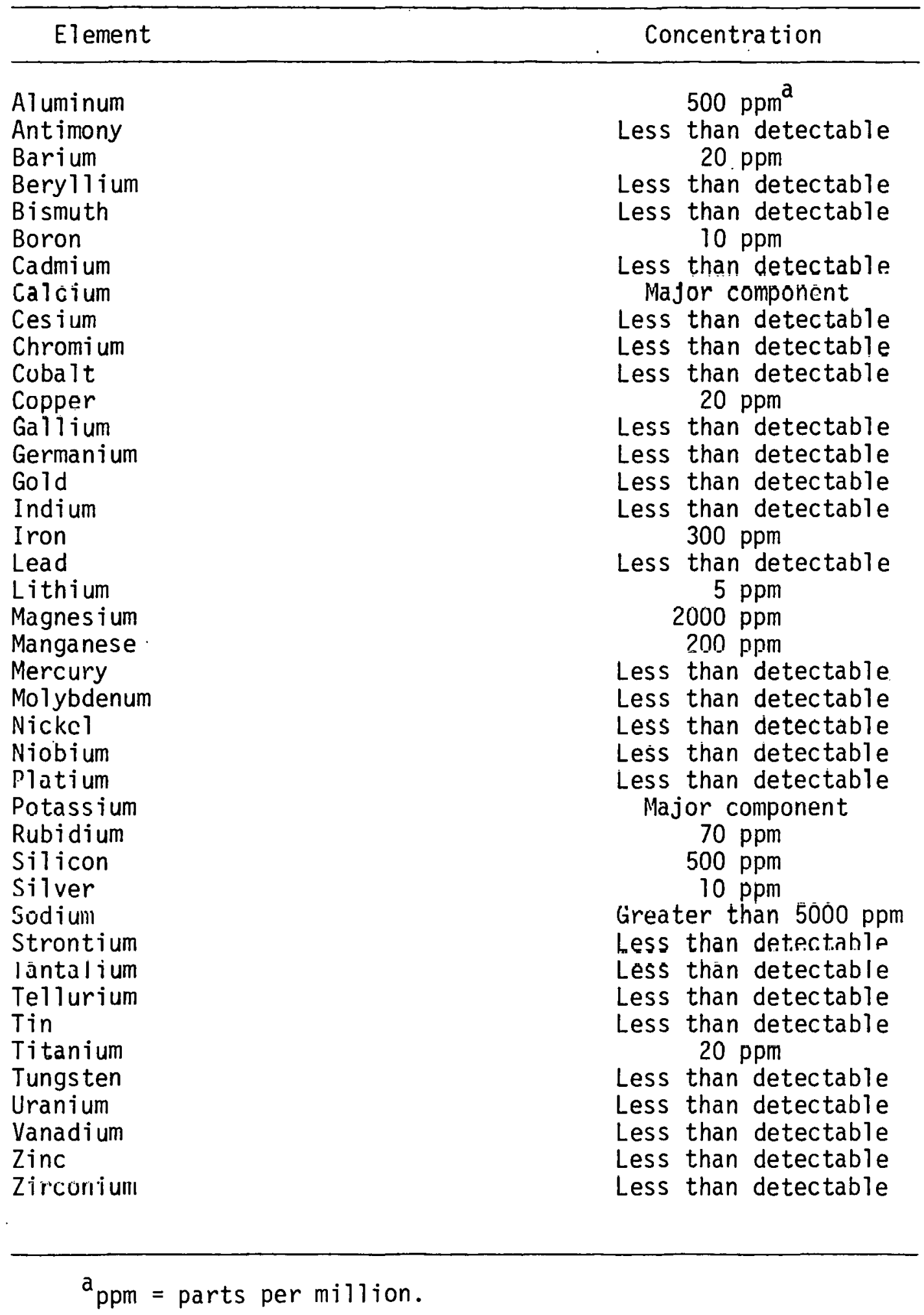


Table A-4. Constants used in the calculation of the population estimates for monitoring experiments one and two

\begin{tabular}{lcc}
\hline Measurement & Smal1 tube & Large tube \\
\hline Inside diameter & $3.1 \mathrm{~cm}$ & $4.7 \mathrm{~cm}$ \\
Outside diameter & $3.8 \mathrm{~cm}$ & $5.1 \mathrm{~cm}$ \\
$k_{s}$ & 0.4064 & 0.5244 \\
$k_{m}$ & 0.5936 & 0.4756 \\
$c$ & 0.1781 1iter & 0.4094 liter \\
\hline
\end{tabular}


Table A-5. Means used to calculate populaticn estimates for aquarium one, experiment one

\begin{tabular}{|c|c|c|c|c|c|c|c|c|c|c|c|c|c|c|c|c|c|}
\hline \multirow[b]{2}{*}{ Day } & \multirow[b]{2}{*}{$n$} & \multicolumn{4}{|c|}{ Adults } & \multicolumn{4}{|c|}{ Capepcidids } & \multicolumn{4}{|c|}{ Niaupli i } & \multicolumn{4}{|c|}{ Totals } \\
\hline & & $\bar{x}_{s}$ & $\mathrm{SE}^{\mathrm{a}}$ & $\bar{x}_{m}$ & SE & $\bar{x}_{s}$ & SE & $\bar{x}_{\mathrm{m}}$ & SE & $\bar{x}_{s}$ & SE & $\bar{x}_{m}$ & SE & $\bar{x}_{s}$ & SE & $\bar{x}_{m}$ & SE \\
\hline 15 & 12 & 0.17 & 0.11 & 0.17 & 0.11 & 0.67 & 0.26 & 1.17 & 0.39 & 0.92 & 0.38 & 0.83 & 0.37 & 1.75 & 0.41 & 2.17 & 0.55 \\
\hline 22 & 12 & 1.00 & 0.32 & 0.08 & 0.08 & 5.50 & 1.18 & 2.67 & 0.41 & 1.67 & 0.33 & 1.83 & 0.79 & 8.17 & 1.20 & 4.58 & 1.03 \\
\hline 33 & 5 & 2.80 & 1.39 & 2.20 & 0.73 & 8.80 & 1.11 & 5.80 & 1.32 & 2.20 & 0.37 & 1.40 & 0.75 & 13.80 & 2.44 & 9.40 & 1.33 \\
\hline 40 & 5 & 6.00 & 0.77 & 1.60 & 0.60 & 18.80 & 1.59 & 5.20 & 1.24 & 1.20 & 0.58 & 2.20 & 1.24 & 26.00 & 1.90 & 9.00 & 1.92 \\
\hline 47 & 5 & $5 . c 0$ & 1.92 & 3.80 & 1.02 & 13.20 & 2.27 & 8.80 & 1.28 & 3.20 & 0.20 & 2.60 & 0.93 & 21.40 & 3.49 & 15.20 & 2.06 \\
\hline 54 & 5 & 10.40 & 5.12 & 2.60 & 1.08 & 19.60 & $7.4 ?$ & 7.20 & 1.28 & 1.00 & 0.45 & " 1.60 & 0.60 & 31.00 & 12.3 & 11.40 & 2.36 \\
\hline 61 & 5 & 9.60 & 1.63 & 3.60 & 1.21 & 15.80 & 3.40 & 4.610 & 1.08 & 1.80 & 0.92 & 1.60 & 0.51 & 27.20 & 5.54 & 9.80 & 2.56 \\
\hline 68 & 5 & 9.00 & 2.88 & 5.60 & 1.17 & 10.60 & 2.42 & 12.00 & 1.70 & 3.80 & 1.73 & 2.80 & 0.97 & 23.40 & 4.89 & 20.40 & 2.38 \\
\hline
\end{tabular}

${ }^{a} S E=$ Standard error. 
Table A-6. Means usec to calculate population estimates for aquarium two, experiment one

\begin{tabular}{|c|c|c|c|c|c|c|c|c|c|c|c|c|c|c|c|c|c|}
\hline \multirow[b]{2}{*}{ Day } & \multirow[b]{2}{*}{$n$} & \multicolumn{4}{|c|}{ fdult.s } & \multicolumn{4}{|c|}{ Copepodids } & \multicolumn{4}{|c|}{ Naupli i } & \multicolumn{4}{|c|}{ Totals } \\
\hline & & $\bar{x}_{s}$ & $S E^{\alpha}$ & $\bar{x}_{m}$ & SE & $\bar{x}_{s}$ & SE & $\bar{x}_{m}$ & SE & $\bar{x}_{s}$ & SE & $\bar{x}_{m}$ & SE & $\bar{x}_{s}$ & SE & $\bar{x}_{m}$ & SE \\
\hline 15 & 12 & 0.17 & 0.17 & 0.17 & 0.11 & 0.33 & 0.19 & 0.42 & 0.19 & 0.33 & 0.14 & 0.83 & 0.27 & 0.83 & 0.37 & 1.42 & 0.51 \\
\hline 22 & 12 & 0.50 & 0.23 & 0.08 & 0.08 & 1.67 & 0.43 & 2.67 & 0.50 & 1.42 & 0.42 & 0.58 & 0.23 & 3.58 & 0.60 & 3.33 & 0.47 \\
\hline 33 & 5 & 0.40 & 0.24 & 0.60 & 0.60 & 8.60 & 1.29 & 3.80 & 1.39 & 2.40 & 0.60 & 0.80 & 0.37 & 11.40 & 0.98 & 5.20 & 1.98 \\
\hline 40 & 5 & 2.80 & 0.73 & 1.00 & 0.45 & 9.80 & 3.23 & 3.40 & 1.33 & 1.20 & 0.37 & 0.40 & 0.24 & 13.80 & 4.08 & 4.80 & 1.50 \\
\hline 47 & 5 & 3.80 & 1.24 & 2.00 & 0.63 & 10.20 & 3.83 & 4.00 & 1.14 & 1.20 & 0.58 & 1.80 & 0.58 & 15.20 & 5.57 & 7.80 & 1.46 \\
\hline 54 & 5 & 2.60 & 1.44 & 2.80 & 0.86 & 8.40 & 2.40 & 5.00 & 0.55 & 0.80 & 0.58 & 1.80 & 0.58 & 11.80 & 3.40 & 9.60 & 0.75 \\
\hline 61 & 5 & 7.20 & 2.40 & 4.00 & 1.18 & 9.20 & 1.07 & 6.00 & 1.05 & 2.20 & 0.37 & 1.80 & 0.49 & 18.60 & 2.29 & 11.80 & 1.56 \\
\hline 68 & 5 & 6.60 & 1.63 & 2.60 & 0.51 & 9.60 & 1.33 & 9.20 & 1.36 & 3.20 & 0.66 & 2.20 & 0.73 & 19.40 & 2.48 & 14.00 & 1.70 \\
\hline
\end{tabular}

\footnotetext{
${ }^{{ }^{\mathrm{S}}} \mathrm{SE}=$ Standard error.
} 
Table A-7. Means used to calculate population estimates for aquarium =hree, experiment one

\begin{tabular}{|c|c|c|c|c|c|c|c|c|c|c|c|c|c|c|c|c|c|}
\hline \multirow[b]{2}{*}{ Day } & \multirow[b]{2}{*}{$n$} & \multicolumn{4}{|c|}{ Adults } & \multicolumn{4}{|c|}{ Copepodids } & \multicolumn{4}{|c|}{ Nauplii } & \multicolumn{4}{|c|}{ Totals } \\
\hline & & $\bar{x}_{s}$ & $S E^{a}$ & $\bar{x}_{\mathrm{m}}$ & SE & $\bar{x}_{s}$ & SE & $\bar{x}_{m}$ & SE & $\bar{x}_{s}$ & SE & $\bar{x}_{\mathrm{m}}$ & SE & $\bar{x}_{s}$ & SE & $\bar{x}_{m}$ & SE \\
\hline 15 & 12 & 0.42 & 0.19 & 0.17 & 0.11 & 0.08 & 0.08 & 0.50 & 0.19 & 0.75 & 0.35 & 0.33 & 0.19 & 1.25 & 0.45 & 1.00 & 0.21 \\
\hline 22 & 12 & 0.33 & 0.19 & 3 & - & 1.33 & 0.28 & 1.08 & 0.23 & 1.00 & 0.35 & 0.42 & 0.19 & 2.67 & 0.40 & 1.50 & 0.45 \\
\hline 33 & 5 & 0.20 & 0.20 & 3 & - & 3.80 & 0.97 & 1.60 & 0.51 & 0 & - & 0 & - & 4.00 & 0.95 & 1.60 & 0.51 \\
\hline 40 & 5 & 1.20 & 0.73 & 0 & - & 3.80 & 2.06 & 0.60 & 0.24 & 0 & - & 0 & - & 5.00 & 2.76 & 0.60 & 0.24 \\
\hline 47 & 5 & 2.00 & 1.05 & 0.40 & 0.24 & 2.80 & 0.66 & 1.00 & 0.32 & 0 & - & 0.40 & 0.24 & 4.80 & 1.36 & 1.80 & 0.58 \\
\hline 54 & 5 & 1.20 & 0.73 & 0.60 & 0.40 & 1.40 & 0.93 & 2.20 & 0.73 & 0 & - & 0.20 & 0.20 & 2.60 & 1.63 & 3.00 & 1.05 \\
\hline 61 & 5 & 3.80 & 1.11 & 0.40 & 0.40 & 2.80 & 1.39 & 1.40 & 0.51 & 0 & - & 0 & - & 6.60 & 2.18 & 1.80 & 0.58 \\
\hline 68 & 5 & 2.20 & 0.49 & 2.00 & 0.77 & 1.60 & 0.24 & 0.40 & 0.40 & 0.80 & 0.37 & 1.00 & 0.45 & 4.60 & 0.40 & 3.40 & 1.12 \\
\hline
\end{tabular}


Table A-8. Means used to calculate population estimates for aquarium four, experiment one

\begin{tabular}{|c|c|c|c|c|c|c|c|c|c|c|c|c|c|c|c|c|c|}
\hline \multirow[b]{2}{*}{ Day } & \multirow[b]{2}{*}{$n$} & \multicolumn{4}{|c|}{ Adults } & \multicolumn{4}{|c|}{ Copepodids } & \multicolumn{4}{|c|}{ Nauplij } & \multicolumn{4}{|c|}{ Totals } \\
\hline & & $\bar{x}_{s}$ & $S E^{\mathrm{a}}$ & $\bar{x}_{m}$ & SE & $\bar{x}_{s}$ & SE & $\bar{x}_{m}$ & SE & $\bar{x}_{s}$ & SE & $\bar{x}_{m}$ & SE & $\bar{x}_{s}$ & SE & $\bar{x}_{m}$ & SE \\
\hline 10 & 12 & 0.67 & 0.36 & 0.80 & 0.08 & 0.42 & 0.19 & 0.92 & 0.26 & 0.83 & 0.30 & 0.50 & 0.19 & 1.92 & 0.43 & 1.50 & 0.45 \\
\hline 17 & 12 & 0.33 & 0.26 & 0.33 & 0.19 & 0.67 & 0.22 & 0.67 & 0.26 & 0.50 & 0.15 & 0.33 & 0.19 & 1.50 & 0.45 & 1.33 & 0.43 \\
\hline 28 & 5 & 0 & - & 0.40 & 0.24 & 0.40 & 0.24 & 0.20 & 0.20 & 0 & - & 0 & - & 0.40 & 0.24 & 0.60 & 0.24 \\
\hline 35 & 5 & 0 & - & 0 & - & 0 & - & 0 & - & 0 & - & 0 & - & 0 & - & 0 & - \\
\hline
\end{tabular}

\footnotetext{
${ }^{a} S E=$ Standard error.
} 
Table A-9. Means used :o calculate populatior estimates for aquarium five, experiment one

\begin{tabular}{|c|c|c|c|c|c|c|c|c|c|c|c|c|c|c|c|c|c|}
\hline \multirow[b]{2}{*}{ Day } & \multirow[b]{2}{*}{$n$} & \multicolumn{4}{|c|}{ Adults } & \multicolumn{4}{|c|}{ Cofeprodids } & \multicolumn{4}{|c|}{ Nauplii } & \multicolumn{4}{|c|}{ Totals } \\
\hline & & $\bar{x}_{s}$ & $S E^{\mathrm{a}}$ & $\bar{x}_{m}$ & SE & $\bar{x}_{s}$ & SE & $\bar{x}_{m}$ & SE & $\bar{x}_{s}$ & SE & $\bar{x}_{m}$ & $S E$ & $\bar{x}_{s}$ & SE & $\bar{x}_{m}$ & SE \\
\hline 10 & 12 & 0 & - & 0.25 & 0.13 & 0.17 & 0.11 & 0.67 & 0.26 & 0.42 & 0.19 & 1.00 & 0.30 & 0.58 & 0.23 & 1.92 & 0.40 \\
\hline 17 & 12 & $0.6 \bar{i}$ & 0.36 & 0.08 & 0.03 & 4.67 & 1.47 & 1.33 & 0.19 & 0.67 & 0.29 & 1.08 & 0.30 & 6.00 & 1.68 & 2.50 & 1.40 \\
\hline 28 & 5 & 4.20 & 0.97 & 2.00 & 0.71 & 4.40 & 1.08 & 2.80 & 0.20 & 1.20 & 0.58 & 3.20 & 1.07 & 9.80 & 1.46 & 8.00 & 4.33 \\
\hline 35 & 5 & 5.00 & 1.05 & 3.40 & 0.63 & 4.40 & 0.98 & 2.60 & 0.40 & 2.00 & 0.45 & 0.80 & 0.58 & 11.40 & 1.96 & 6.80 & 0.86 \\
\hline 42 & 5 & 9.80 & 2.87 & 1.20 & 0.37 & 7.60 & 2.20 & 2.80 & 0.20 & 3.20 & 0.49 & 3.40 & 0.81 & 20.60 & 4.55 & 7.40 & 0.51 \\
\hline 49 & 5 & 4.60 & 1.21 & 3.60 & 2.17 & 7.00 & 1.79 & 4.20 & 1.79 & 1.00 & 0.45 & 1.20 & 10.58 & 12.60 & 3.01 & 9.00 & 2.12 \\
\hline 56 & 5 & 8.40 & 0.93 & 4.40 & 0.66 & 7.80 & 0.97 & 7.00 & 2.81 & 1.60 & 0.60 & 1.80 & 0.80 & 17.80 & 2.27 & 13.20 & 2.69 \\
\hline 63 & 5 & 9.60 & 2.32 & 9.00 & 2.70 & 11.40 & 1.75 & 8.40 & 2.36 & 4.60 & 1.60 & 5.20 & 3.58 & 25.60 & 3.56 & 22.60 & 4.91 \\
\hline
\end{tabular}

$a_{S E}=$ Ständard error. 
Table A-10. Means used to calculate population estimates for aquarium six, experiment one

\begin{tabular}{|c|c|c|c|c|c|c|c|c|c|c|c|c|c|c|c|c|c|}
\hline \multirow[b]{2}{*}{ Day } & \multirow[b]{2}{*}{$n$} & \multicolumn{4}{|c|}{ Adults } & \multicolumn{4}{|c|}{ Copepodids } & \multicolumn{4}{|c|}{ Naupli i } & \multicolumn{4}{|c|}{ Totals } \\
\hline & & $\bar{x}_{s}$ & $S E^{\mathrm{a}}$ & $\bar{x}_{m}$ & SE & $\bar{x}_{s}$ & SE & $\bar{x}_{m}$ & SE & $\bar{x}_{s}$ & SE & $\bar{x}_{m}$ & SE & $\overline{\bar{x}}_{s}$ & SE & $\bar{x}_{m}$ & SE \\
\hline 10 & 12 & 0.67 & 0.28 & 0.25 & 0.13 & 0.58 & 0.26 & 1.33 & 0.51 & 0.92 & 0.29 & 1.33 & 0.31 & 2.17 & 0.37 & 2.92 & 0.56 \\
\hline 17 & 12 & 0.25 & 0.78 & 0.17 & 0.12 & 5.00 & 1.00 & 3.83 & 0.81 & 2.08 & 0.42 & 0.92 & 0.34 & 7.33 & 1.40 & 4.92 & 0.96 \\
\hline 28 & 5 & 2.50 & 0.40 & 1.20 & 0.73 & 21.40 & 3.92 & 10.80 & 2.50 & 1.40 & 0.51 & 0 & - & 25.20 & 4.33 & 12.00 & 2.81 \\
\hline 35 & 5 & 6.20 & 4.08 & 1.40 & 0.40 & 15.20 & 6.42 & 4.20 & 0.73 & 0 & - & 0.40 & 0.24 & 21.40 & 10.4 & 6.00 & 1.05 \\
\hline 42 & 5 & 1.40 & 0.24 & 1.20 & 0.73 & 9.80 & 2.11 & 10.80 & 1.59 & 2.80 & 0.92 & 2.40 & 1.29 & 14.00 & 2.45 & 14.40 & 1.36 \\
\hline 49 & 5 & 2.40 & 0.81 & 5.20 & 1.16 & 7.80 & 2.56 & 8.80 & 2.03 & 2.80 & 0.86 & 3.60 & 0.98 & 13.00 & 3.58 & 17.60 & 3.50 \\
\hline 56 & 5 & 4.20 & 0.37 & 3.40 & 0.66 & 7.80 & .7 .71 & 12.20 & 1.02 & 2.20 & 0.20 & 3.80 & 0.92 & 14.20 & 1.85 & 19.40 & 1.63 \\
\hline 63 & 5 & 5.20 & 1.76 & 2.40 & 0.51 & 12.20 & 1.69 & 9.80 & 1.85 & 4.80 & 1.16 & 4.60 & 1.16 & 22.20 & 2.91 & 16.80 & .3 .25 \\
\hline
\end{tabular}

${ }^{a} \mathrm{SE}=$ Standard error. 
Table A-11. Means used to calculate pofulation estimates for aquarium one, experiment two

\begin{tabular}{|c|c|c|c|c|c|c|c|c|c|c|c|c|c|c|c|c|c|}
\hline \multirow[b]{2}{*}{ Day } & \multirow[b]{2}{*}{$\mathrm{n}$} & \multicolumn{4}{|c|}{ Adults } & \multicolumn{4}{|c|}{ Copepodids } & \multicolumn{4}{|c|}{ Naupli i } & \multicolumn{4}{|c|}{ Totals } \\
\hline & & $\bar{x}_{s}$ & $S E^{a}$ & $\bar{x}_{m}$ & SE & $\bar{x}_{s}$ & SE & $\bar{x}_{m}$ & SE & $\bar{x}_{s}$ & SE & $\bar{x}_{\mathrm{m}}$ & SE & $\bar{x}_{s}$ & SE & $\bar{x}_{\mathrm{m}}$ & SE \\
\hline $\begin{array}{r}8 \\
15 \\
22 \\
29 \\
36 \\
43 \\
50 \\
57 \\
64 \\
72 \\
79 \\
86 \\
92 \\
99 \\
107 \\
114 \\
121 \\
128 \\
134 \\
141 \\
148 \\
155 \\
162 \\
169 \\
176 \\
183 \\
190 \\
197 \\
205\end{array}$ & $\begin{array}{l}5 \\
5 \\
5 \\
5 \\
5 \\
5 \\
5 \\
5 \\
5 \\
5 \\
5 \\
5 \\
5 \\
5 \\
5 \\
5 \\
5 \\
5 \\
5 \\
5 \\
5 \\
5 \\
5 \\
5 \\
3 \\
3 \\
3 \\
3 \\
3\end{array}$ & $\begin{array}{r}3.0 \\
1.4 \\
2.2 \\
3.2 \\
5.8 \\
16.0 \\
13.2 \\
20.6 \\
11.2 \\
20.0 \\
18.4 \\
17.2 \\
17.8 \\
10.4 \\
10.8 \\
12.6 \\
25.4 \\
8.2 \\
15.4 \\
7.0 \\
5.0 \\
8.2 \\
6.6 \\
4.0 \\
3 . \overline{3} \\
4.0 \\
3 . \overline{3} \\
1 . \overline{3} \\
0 . \overline{3}\end{array}$ & $\begin{array}{r}0.84 \\
0.51 \\
1.11 \\
0.73 \\
2.44 \\
6.57 \\
6.09 \\
9.44 \\
2.48 \\
10.66 \\
3.12 \\
3.54 \\
3.90 \\
1.47 \\
1.02 \\
5.04 \\
14.64 \\
1.28 \\
4.49 \\
2.49 \\
2.43 \\
2.18 \\
1.81 \\
1.10 \\
0.3 \overline{3} \\
2.08 \\
2.03 \\
0.67 \\
0.3 \overline{3}\end{array}$ & $\begin{array}{r}1.2 \\
0.2 \\
0.6 \\
2.2 \\
2.0 \\
3.0 \\
7.8 \\
7.4 \\
4.6 \\
4.2 \\
1.8 \\
4.2 \\
5.8 \\
4.8 \\
13.0 \\
4.4 \\
4.0 \\
1.8 \\
2.4 \\
1.0 \\
1.0 \\
1.4 \\
1.6 \\
0.4 \\
1.0 \\
1.0 \\
0 \\
0.5 \\
0.3\end{array}$ & $\begin{array}{l}0.58 \\
0.20 \\
0.24 \\
0.58 \\
0.45 \\
0.71 \\
1.53 \\
1.17 \\
1.03 \\
1.07 \\
0.58 \\
0.49 \\
1.16 \\
1.07 \\
6.38 \\
0.68 \\
1.10 \\
0.73 \\
0.68 \\
0.32 \\
C .45 \\
C .51 \\
C .40 \\
C .24 \\
0.58 \\
0.58 \\
0.3 \overline{3} \\
0.3 \overline{3}\end{array}$ & $\begin{array}{r}2.4 \\
6.8 \\
10.0 \\
9.0 \\
9.0 \\
10.8 \\
6.8 \\
10.8 \\
6.4 \\
18.2 \\
14.0 \\
13.2 \\
14.4 \\
7.8 \\
5.4 \\
2.8 \\
7.8 \\
2.4 \\
4.0 \\
1.4 \\
0.4 \\
0.4 \\
0 \\
0 \\
0 \\
1 . \overline{3} \\
0 . \overline{3} \\
0 . \overline{3} \\
0 . \overline{3}\end{array}$ & $\begin{array}{l}C .93 \\
1.77 \\
C .45 \\
1.76 \\
1.87 \\
4.31 \\
1.36 \\
5.96 \\
1.27 \\
12.49 \\
5.24 \\
i .40 \\
5.45 \\
1.93 \\
0.81 \\
1.02 \\
3.77 \\
0.81 \\
2.28 \\
0.51 \\
0.24 \\
0.40 \\
- \\
- \\
- \\
0.88 \\
0.3 \overline{3} \\
0.3 \overline{3} \\
0.3 \overline{3}\end{array}$ & $\begin{array}{c}3.6 \\
4.8 \\
4.0 \\
5.8 \\
3.6 \\
2.4 \\
2.8 \\
3.0 \\
3.8 \\
2.2 \\
2.2 \\
3.2 \\
2.6 \\
1.8 \\
3.2 \\
0.6 \\
0.6 \\
0.8 \\
0.8 \\
0.2 \\
0 \\
0 \\
0 \\
0.2 \\
0 . \overline{3} \\
0 . \overline{3} \\
0 . \overline{3} \\
0 \\
0 . \overline{3}\end{array}$ & $\begin{array}{l}0.68 \\
0.86 \\
1.10 \\
1.32 \\
1.29 \\
0.60 \\
0.80 \\
0.63 \\
1.36 \\
0.58 \\
0.37 \\
0.58 \\
0.51 \\
0.58 \\
1.98 \\
0.24 \\
0.24 \\
0.37 \\
0.37 \\
0.20 \\
- \\
- \\
- \\
0.20 \\
- \\
0.3 \overline{3} \\
0.3 \overline{3} \\
- \\
0.3 \overline{3}\end{array}$ & $\begin{array}{l}1.4 \\
3.2 \\
3.2 \\
1.6 \\
1.4 \\
6.0 \\
4.6 \\
9.2 \\
5.2 \\
3.4 \\
5.6 \\
3.6 \\
2.0 \\
1.2 \\
1.4 \\
1.2 \\
0.4 \\
0.8 \\
2.4 \\
2.0 \\
0.6 \\
0.8 \\
1.4 \\
0.8 \\
1.0 \\
1 . \overline{3} \\
0 . \overline{3} \\
1.0 \\
0.6\end{array}$ & $\begin{array}{l}0.24 \\
0.66 \\
0.58 \\
0.51 \\
0.40 \\
1.10 \\
1.27 \\
6.97 \\
1.36 \\
1.72 \\
1.17 \\
1.21 \\
1.26 \\
0.58 \\
0.51 \\
0.37 \\
0.40 \\
0.37 \\
0.75 \\
0.84 \\
0.24 \\
0.37 \\
0.68 \\
0.37 \\
0.58 \\
0.88 \\
0.33 \\
- \\
0.33\end{array}$ & $\begin{array}{l}1.6 \\
4.0 \\
2.2 \\
2.4 \\
2.4 \\
5.4 \\
4.6 \\
4.8 \\
6.0 \\
2.2 \\
4.4 \\
1.8 \\
5.0 \\
2.0 \\
1.0 \\
0.6 \\
1.2 \\
0.8 \\
2.4 \\
0.8 \\
0.4 \\
1.2 \\
0.6 \\
0.4 \\
0.3 \\
1 . \overline{3} \\
0 \\
0.6 \\
0 . \overline{3}\end{array}$ & $\begin{array}{l}0.93 \\
1.00 \\
0.58 \\
0.51 \\
0.40 \\
1.86 \\
1.86 \\
1.02 \\
1.38 \\
0.66 \\
0.9 \overline{4} \\
0.37 \\
1.41 \\
- \\
- \\
0.40 \\
0.37 \\
0.37 \\
0.75 \\
0.20 \\
0.40 \\
0.58 \\
0.24 \\
0.24 \\
0.3 \overline{3} \\
0.3 \overline{3} \\
- \\
0.3 \overline{3} \\
0.3 \overline{3}\end{array}$ & $\begin{array}{r}6.8 \\
11.4 \\
15.4 \\
13.8 \\
16.2 \\
32.8 \\
24.6 \\
40.6 \\
22.8 \\
41.6 \\
38.0 \\
34.0 \\
34.2 \\
19.4 \\
17.6 \\
16.6 \\
33.6 \\
11.4 \\
21.8 \\
10.4 \\
6.0 \\
9.4 \\
8.0 \\
4.8 \\
4 . \overline{3} \\
6 . \overline{6} \\
4.0 \\
2.6 \\
1 . \overline{3}\end{array}$ & $\begin{array}{r}0.58 \\
1.29 \\
1.63 \\
2.63 \\
4.02 \\
7.50 \\
8.31 \\
22.06 \\
4.14 \\
24.17 \\
6.28 \\
5.59 \\
9.80 \\
3.14 \\
1.25 \\
5.96 \\
18.30 \\
1.81 \\
6.24 \\
2.98 \\
2.59 \\
2.38 \\
1.70 \\
0.97 \\
0.6 \overline{6} \\
2.19 \\
2.08 \\
0.3 \overline{3} \\
0.3 \overline{3}\end{array}$ & $\begin{array}{r}6.4 \\
9.0 \\
6.8 \\
10.4 \\
8.0 \\
10.8 \\
15.2 \\
15.2 \\
14.4 \\
8.6 \\
8.4 \\
9.2 \\
13.4 \\
8.6 \\
17.2 \\
5.6 \\
5.8 \\
3.4 \\
5.6 \\
2.0 \\
1.4 \\
2.6 \\
2.2 \\
1.0 \\
1.3 \\
2.6 \\
0.5 \\
1.3 \\
1.0\end{array}$ & $\begin{array}{l}1.57 \\
0.89 \\
1.07 \\
1.86 \\
1.41 \\
1.28 \\
2.24 \\
1.11 \\
2.58 \\
1.40 \\
1.36 \\
0.86 \\
2.38 \\
1.50 \\
8.41 \\
0.93 \\
0.97 \\
1.36 \\
1.72 \\
0.45 \\
0.40 \\
1.08 \\
0.37 \\
0.32 \\
0.88 \\
1.20 \\
0.33 \\
0.33 \\
0.58\end{array}$ \\
\hline
\end{tabular}

${ }^{a} S E=$ Standĩrd error. 
Table A-12. Means used to calculate population estimates for aquarium two, experiment two

\begin{tabular}{|c|c|c|c|c|c|c|c|c|c|c|c|c|c|c|c|c|c|}
\hline \multirow[b]{2}{*}{ Day } & \multirow[b]{2}{*}{$n$} & \multicolumn{4}{|c|}{ Adults } & \multicolumn{4}{|c|}{ Copepodids } & \multicolumn{4}{|c|}{ Naupli $i$} & \multicolumn{4}{|c|}{ Totals } \\
\hline & & $\bar{x}_{s}$ & $S E^{a}$ & $\bar{x}_{m}$ & SE & $\bar{x}_{s}$ & SE & $\bar{x}_{m}$ & SE & $\bar{x}_{s}$ & SE & $\bar{x}_{m}$ & SE & $\bar{x}_{s}$ & SE & $\bar{x}_{\mathrm{m}}$ & SE \\
\hline $\begin{array}{r}8 \\
15 \\
22 \\
29 \\
36 \\
43 \\
50 \\
57 \\
64 \\
72 \\
79 \\
86 \\
92 \\
99 \\
107 \\
114 \\
121 \\
128 \\
134 \\
141 \\
148 \\
155 \\
162 \\
169 \\
176 \\
183 \\
190 \\
197 \\
205\end{array}$ & $\begin{array}{l}5 \\
5 \\
5 \\
5 \\
5 \\
5 \\
5 \\
5 \\
5 \\
5 \\
5 \\
5 \\
5 \\
5 \\
5 \\
5 \\
5 \\
5 \\
5 \\
5 \\
5 \\
5 \\
5 \\
5 \\
3 \\
3 \\
3 \\
3 \\
3\end{array}$ & $\begin{array}{r}3.2 \\
1.2 \\
1.2 \\
1.0 \\
4.4 \\
4.8 \\
15.4 \\
16.0 \\
14.8 \\
15.6 \\
25.0 \\
23.4 \\
20.6 \\
20.6 \\
31.4 \\
27.4 \\
21.4 \\
18.6 \\
17.8 \\
25.8 \\
18.8 \\
11.0 \\
13.2 \\
8.4 \\
6 . \overline{3} \\
9 . \overline{3} \\
8.0 \\
12 . \overline{6} \\
3 . \overline{6}\end{array}$ & $\begin{array}{l}1.56 \\
0.58 \\
0.37 \\
0.45 \\
0.81 \\
1.43 \\
5.78 \\
1.92 \\
3.84 \\
4.63 \\
8.50 \\
6.52 \\
4.99 \\
4.52 \\
9.95 \\
7.55 \\
7.64 \\
6.58 \\
4.42 \\
5.65 \\
8.38 \\
3.21 \\
3.89 \\
2.98 \\
2.36 \\
4.66 \\
3.21 \\
2.3 \overline{3} \\
1.3 \overline{3}\end{array}$ & $\begin{array}{r}0.8 \\
1.2 \\
2.0 \\
0.6 \\
3.2 \\
3.4 \\
4.8 \\
5.8 \\
5.8 \\
8.2 \\
7.2 \\
6.8 \\
11.8 \\
8.4 \\
8.0 \\
9.2 \\
7.0 \\
10.6 \\
11.8 \\
5.8 \\
5.8 \\
5.8 \\
4.4 \\
3.0 \\
3.0 \\
2 . \overline{6} \\
3 . \overline{3} \\
1 . \overline{6} \\
1.0\end{array}$ & $\begin{array}{l}0.20 \\
0.73 \\
0.84 \\
0.40 \\
1.24 \\
0.93 \\
1.36 \\
1.74 \\
1.39 \\
0.58 \\
1.71 \\
1.50 \\
3.02 \\
0.68 \\
1.58 \\
1.50 \\
1.97 \\
1.47 \\
0.86 \\
0.97 \\
1.02 \\
0.80 \\
0.93 \\
0.71 \\
0.58 \\
0.3 \overline{3} \\
0.6 \overline{6} \\
0.88 \\
0.58\end{array}$ & $\begin{array}{r}4.2 \\
4.2 \\
7.8 \\
7.8 \\
9.0 \\
4.0 \\
10.0 \\
11.8 \\
14.4 \\
19.8 \\
13.2 \\
21.8 \\
11.6 \\
6.8 \\
8.0 \\
8.0 \\
8.0 \\
3.8 \\
2.2 \\
0.8 \\
0.8 \\
1.0 \\
9.6 \\
5.2 \\
3 . \overline{6} \\
3 . \overline{6} \\
1 . \overline{3} \\
4 . \overline{3} \\
2 . \overline{6}\end{array}$ & $\begin{array}{l}0.97 \\
1.50 \\
0.86 \\
2.27 \\
3.66 \\
0.71 \\
4.55 \\
3.37 \\
4.30 \\
7.62 \\
4.33 \\
5.50 \\
1.81 \\
1.66 \\
2.24 \\
2.92 \\
2.39 \\
1.59 \\
0.80 \\
0.58 \\
0.37 \\
0.45 \\
4.55 \\
4.45 \\
2.73 \\
2.33 \\
0.88 \\
1.76 \\
1.76\end{array}$ & $\begin{array}{l}3.6 \\
6.4 \\
5.0 \\
6.0 \\
5.8 \\
3.8 \\
4.6 \\
4.8 \\
5.8 \\
4.8 \\
5.2 \\
4.0 \\
4.8 \\
3.4 \\
3.0 \\
1.6 \\
1.6 \\
0.4 \\
0.8 \\
0.2 \\
0.2 \\
0.6 \\
3.2 \\
1.2 \\
2 . \overline{3} \\
1 . \overline{3} \\
0 . \overline{6} \\
2.0 \\
0 . \overline{3}\end{array}$ & $\begin{array}{l}0.87 \\
1.12 \\
0.89 \\
2.21 \\
1.43 \\
0.37 \\
0.93 \\
1.16 \\
1.98 \\
1.32 \\
2.31 \\
0.45 \\
1.36 \\
1.40 \\
0.84 \\
0.40 \\
0.60 \\
0.24 \\
0.37 \\
0.20 \\
0.20 \\
0.40 \\
0.86 \\
0.37 \\
1.86 \\
0.3 \overline{3} \\
0.6 \overline{6} \\
- \\
0.3 \overline{3}\end{array}$ & $\begin{array}{r}3.8 \\
4.0 \\
5.4 \\
2.2 \\
1.0 \\
3.0 \\
4.8 \\
11.4 \\
6.8 \\
9.2 \\
4.2 \\
6.0 \\
8.0 \\
0.8 \\
1.0 \\
1.0 \\
0.8 \\
0.6 \\
8.8 \\
5.0 \\
19.8 \\
3.2 \\
4.4 \\
4.0 \\
1.6 \\
2 . \overline{3} \\
4.0 \\
3.0 \\
1.3\end{array}$ & $\begin{array}{r}0.49 \\
0.84 \\
1.89 \\
0.20 \\
0.32 \\
1.14 \\
2.03 \\
2.01 \\
1.50 \\
2.24 \\
0.92 \\
1.30 \\
2.07 \\
0.37 \\
0.32 \\
0.45 \\
0.49 \\
0.40 \\
2.46 \\
1.30 \\
17.30 \\
1.16 \\
0.51 \\
1.84 \\
0.3 \overline{3} \\
0.6 \overline{6} \\
1.15 \\
2.52 \\
0.88\end{array}$ & $\begin{array}{r}6.0 \\
4.6 \\
5.0 \\
1.4 \\
1.6 \\
2.6 \\
5.0 \\
11.0 \\
11.2 \\
7.2 \\
3.8 \\
4.2 \\
3.8 \\
1.6 \\
1.2 \\
0.4 \\
1.4 \\
2.4 \\
4.2 \\
3.8 \\
4.0 \\
2.2 \\
2.2 \\
1.2 \\
2 . \frac{3}{3} \\
1.3 \\
1.6 \\
1.6 \\
0.3\end{array}$ & $\begin{array}{l}1.10 \\
0.93 \\
1.00 \\
0.75 \\
0.51 \\
0.68 \\
0.55 \\
0.84 \\
1.24 \\
1.20 \\
0.66 \\
1.24 \\
1.66 \\
0.24 \\
0.49 \\
0.24 \\
0.24 \\
0.60 \\
0.20 \\
0.58 \\
0.84 \\
0.20 \\
0.73 \\
0.37 \\
0.6 \overline{6} \\
0.88 \\
0.3 \overline{3} \\
1.20 \\
0.3 \overline{3}\end{array}$ & $\begin{array}{r}11.2 \\
9.4 \\
14.4 \\
11.0 \\
14.4 \\
11.8 \\
30.2 \\
39.2 \\
36.0 \\
44.6 \\
42.4 \\
51.2 \\
40.2 \\
28.2 \\
40.4 \\
36.4 \\
30.2 \\
23.0 \\
28.8 \\
31.6 \\
39.4 \\
15.2 \\
27.2 \\
17.6 \\
11.6 \\
15.3 \\
13.3 \\
20.0 \\
7.6\end{array}$ & $\begin{array}{r}1.36 \\
2.38 \\
1.96 \\
2.35 \\
4.26 \\
2.73 \\
9.67 \\
4.53 \\
6.73 \\
14.23 \\
9.73 \\
12.04 \\
5.88 \\
5.90 \\
12.34 \\
9.87 \\
9.92 \\
7.80 \\
6.89 \\
6.58 \\
25.94 \\
3.04 \\
8.39 \\
9.16 \\
4.18 \\
6.39 \\
4.84 \\
5.51 \\
2.60\end{array}$ & $\begin{array}{r}10.4 \\
12.2 \\
12.0 \\
8.0 \\
10.6 \\
9.8 \\
14.4 \\
21.6 \\
22.8 \\
20.2 \\
16.2 \\
15.0 \\
20.4 \\
13.4 \\
12.2 \\
11.2 \\
10.0 \\
13.4 \\
16.8 \\
9.8 \\
10.0 \\
8.6 \\
9.8 \\
5.4 \\
7 . \overline{6} \\
5 . \overline{3} \\
5 . \overline{6} \\
5 . \overline{3} \\
1.6\end{array}$ & $\begin{array}{l}1.33 \\
1.24 \\
1.58 \\
2.14 \\
1.44 \\
1.02 \\
2.44 \\
2.62 \\
2.42 \\
1.96 \\
3.90 \\
1.67 \\
4.35 \\
2.01 \\
2.48 \\
1.77 \\
2.35 \\
1.50 \\
1.02 \\
1.02 \\
0.84 \\
1.08 \\
1.88 \\
0.75 \\
1.66 \\
0.33 \\
1.20 \\
0.66 \\
0.88\end{array}$ \\
\hline
\end{tabular}

${ }^{a} S E=$ standard error. 
Table A-13. Breeding parameters for aquaria one through six, experiment one

\begin{tabular}{|c|c|c|c|c|c|c|c|}
\hline \multirow[b]{2}{*}{ Day } & \multicolumn{3}{|c|}{ Clutch size } & \multirow{2}{*}{$\begin{array}{l}\text { Proportion } \\
\text { ovigerous } \\
\text { females }\end{array}$} & \multirow{2}{*}{$\begin{array}{l}\text { Sex ratio } \\
\text { males } \\
\text { females }\end{array}$} & \multirow{2}{*}{$\begin{array}{l}\text { Finite } \\
\text { birth } \\
\text { rate }(B)\end{array}$} & \multirow{2}{*}{$\frac{\text { No. eggs }}{\text { liter }}$} \\
\hline & Mean & $\mathrm{SE}^{\mathrm{a}}$ & $n$ & & & & \\
\hline
\end{tabular}

-----Aquarium one-----

$\begin{array}{rrrrccrr}15 & 7.50 & 0.50 & 2 & 0.50 & \text { Fema les } & 1.88 & 3.5 \\ 22 & 9.00 & 2.65 & 3 & 0.27 & 0.18 & 1.23 & 5.3 \\ 33 & 15.50 & 6.50 & 2 & 0.17 & 1.08 & 1.29 & 7.6 \\ 40 & 8.30 & 1.16 & 10 & 0.63 & 1.38 & 2.59 & 20.8 \\ 47 & 7.27 & 0.92 & 11 & 0.65 & 1.59 & 2.35 & 19.7 \\ 54 & 4.00 & - & 6 & 0.27 & 1.95 & 0.54 & 6.0 \\ 61 & 5.00 & 0.78 & 8 & 0.40 & 2.30 & 1.00 & 10.0 \\ 68 & 5.33 & 0.50 & 12 & 0.35 & 1.15 & 0.94 & 15.8\end{array}$

-----Aquarium two-----

$\begin{array}{rrrrrrrr}15 & 7.00 & - & 1 & 0.50 & 1.00 & 1.75 & 1.7 \\ 22 & - & - & 0 & 0 & 2.50 & - & - \\ 33 & 6.50 & 0.50 & 2 & 0.67 & 0.67 & 2.17 & 3.1 \\ 40 & 6.00 & - & 1 & 0.17 & 2.17 & 0.50 & 1.5 \\ 47 & 11.20 & 1.71 & 5 & 0.56 & 2.22 & 3.11 & 13.9 \\ 54 & 6.83 & 1.56 & 6 & 0.55 & 1.45 & 1.86 & 10.0 \\ 61 & 5.22 & 0.66 & 9 & 0.50 & 2.11 & 1.30 & 11.6 \\ 68 & 5.50 & 0.96 & 6 & 0.30 & 1.30 & 0.82 & 8.2\end{array}$

-.---Aquarium three------

$\begin{array}{cccccccc}15 & - & - & 0 & 0 & 0.75 & - & - \\ 22 & - & - & 0 & 0 & 1.00 & - & - \\ 33 & - & - & 0 & 0 & \text { Males } & - & - \\ 40 & 6.50 & 0.50 & 2 & 0.68 & 1.00 & 2.17 & 3.4 \\ 47 & - & - & 0 & 0 & 11.00 & \cdots & - \\ 54 & - & - & 0 & 0 & 2.00 & - & - \\ 61 & - & - & 0 & 0 & 2.50 & - & - \\ 68 & 6.40 & 0.68 & 5 & 0.83 & 2.50 & 2.67 & 7.8\end{array}$

-Aquarium four------

$\begin{array}{cccccccc}10 & 9.00 & - & 1 & 0.25 & 1.25 & 1.12 & 1.8 \\ 17 & - & - & 0 & 0 & 1.00 & - & - \\ 28 & - & - & 0 & 0 & \text { Maies } & - & - \\ 35 & - & - & 0 & 0 & 0 & - & -\end{array}$


Table A-13. (continued)

\begin{tabular}{|c|c|c|c|c|c|c|c|}
\hline \multirow[b]{2}{*}{ Day } & \multicolumn{3}{|c|}{ Clutch size } & \multirow{2}{*}{$\begin{array}{l}\text { Proportion } \\
\text { ovigerous } \\
\text { females }\end{array}$} & \multirow{2}{*}{$\begin{array}{l}\text { Sex ratio } \\
\frac{\text { males }}{\text { females }}\end{array}$} & \multirow{2}{*}{$\begin{array}{l}\text { Finite } \\
\text { birth } \\
\text { rate (B) }\end{array}$} & \multirow{2}{*}{$\frac{\text { No. egg }}{\text { liter }}$} \\
\hline & Mean & $S E^{a}$ & $\mathrm{n}$ & & & & \\
\hline \multicolumn{8}{|c|}{-----Aquarium five--.-- } \\
\hline $\begin{array}{l}10 \\
17 \\
28 \\
35 \\
42 \\
49 \\
56 \\
63\end{array}$ & $\begin{array}{r}11.00 \\
8.00 \\
8.60 \\
8.33 \\
8.70 \\
7.33 \\
7.00 \\
6.93\end{array}$ & $\begin{array}{c}- \\
- \\
2.89 \\
0.61 \\
1.03 \\
2.96 \\
0.85 \\
0.69\end{array}$ & $\begin{array}{r}1 \\
2 \\
5 \\
6 \\
10 \\
3 \\
13 \\
15\end{array}$ & $\begin{array}{l}0.50 \\
0.40 \\
0.25 \\
0.38 \\
0.50 \\
0.33 \\
0.50 \\
0.48\end{array}$ & $\begin{array}{l}0.50 \\
0.80 \\
0.55 \\
1.62 \\
1.75 \\
3.56 \\
1.46 \\
2.00\end{array}$ & $\begin{array}{l}2.75 \\
1.60 \\
1.08 \\
1.56 \\
2.18 \\
1.22 \\
1.75 \\
1.68\end{array}$ & $\begin{array}{r}3.0 \\
3.2 \\
10.7 \\
12.3 \\
22.1 \\
5.4 \\
22.6 \\
25.4\end{array}$ \\
\hline \multicolumn{8}{|c|}{---Aquarium six----- } \\
\hline $\begin{array}{l}10 \\
17 \\
28 \\
35 \\
42 \\
49 \\
56 \\
63\end{array}$ & $\begin{array}{c}12.50 \\
- \\
11.00 \\
12.00 \\
7.00 \\
5.29 \\
6.70 \\
5.56\end{array}$ & $\begin{array}{c}4.50 \\
- \\
- \\
- \\
- \\
0.70 \\
1.04 \\
0.58\end{array}$ & $\begin{array}{r}2 \\
0 \\
1 \\
1 \\
1 \\
6 \\
10 \\
9\end{array}$ & $\begin{array}{c}0.20 \\
0 \\
0.08 \\
0.07 \\
0.33 \\
0.50 \\
0.50 \\
0.45\end{array}$ & $\begin{array}{l}1.75 \\
0.67 \\
0.50 \\
1.53 \\
3.33 \\
2.17 \\
0.90 \\
0.90\end{array}$ & $\begin{array}{l}3.12 \\
- \\
0.46 \\
0.40 \\
1.17 \\
1.54 \\
1.68 \\
1.25\end{array}$ & $\begin{array}{c}2.1 \\
- \\
8.8 \\
3.0 \\
1.7 \\
7.6 \\
16.5 \\
12.4\end{array}$ \\
\hline
\end{tabular}


Table A-14. Breeding parameters for aquarium one, experiment two

\begin{tabular}{|c|c|c|c|c|c|c|c|}
\hline \multirow[b]{2}{*}{ Day } & \multicolumn{3}{|c|}{ Clutch size } & \multirow{2}{*}{$\begin{array}{l}\text { Proportion } \\
\text { ovigerous } \\
\text { females }\end{array}$} & \multirow{2}{*}{$\begin{array}{l}\text { Sex ratio } \\
\text { males } \\
\text { female }\end{array}$} & \multirow{2}{*}{$\begin{array}{l}\text { Finite } \\
\text { birth } \\
\text { rate (B) }\end{array}$} & \multirow{2}{*}{$\frac{\text { No. eggs }}{\text { liter }}$} \\
\hline & Mean & $S E^{\mathrm{a}}$ & $n$ & & & & \\
\hline $\begin{array}{r}8 \\
15 \\
22 \\
29 \\
36 \\
43 \\
50 \\
57 \\
64 \\
72 \\
79 \\
86 \\
92 \\
99 \\
107 \\
114 \\
121 \\
128 \\
134 \\
141 \\
148 \\
155 \\
162 \\
169 \\
176 \\
183 \\
190 \\
197 \\
205\end{array}$ & $\begin{array}{r}6.89 \\
8.75 \\
7.00 \\
17.40 \\
12.15 \\
11.61 \\
10.62 \\
9.25 \\
7.00 \\
6.33 \\
3.00 \\
3.86 \\
4.89 \\
- \\
6.00 \\
5.67 \\
4.50 \\
3.50 \\
4.50 \\
6.75 \\
10.00 \\
7.92 \\
9.92 \\
7.20 \\
11.00 \\
10.00 \\
8.00 \\
10.00 \\
10.00\end{array}$ & $\begin{array}{l}0.56 \\
0.75 \\
1.08 \\
3.72 \\
1.37 \\
1.20 \\
0.84 \\
1.16 \\
0.88 \\
0.21 \\
1.00 \\
0.55 \\
1.10 \\
-1 \\
- \\
0.33 \\
0.50 \\
0.50 \\
0.96 \\
1.89 \\
- \\
0.56 \\
1.21 \\
0.73 \\
1.00 \\
1.00 \\
1.00 \\
2.81 \\
-\end{array}$ & $\begin{array}{r}9 \\
4 \\
4 \\
5 \\
13 \\
18 \\
21 \\
20 \\
11 \\
6 \\
2 \\
7 \\
9 \\
0 \\
1 \\
3 \\
4 \\
2 \\
4 \\
4 \\
1 \\
13 \\
13 \\
5 \\
3 \\
2 \\
2 \\
5 \\
1\end{array}$ & $\begin{array}{l}1.00 \\
1.00 \\
0.67 \\
0.38 \\
0.65 \\
0.43 \\
0.54 \\
0.38 \\
0.29 \\
0.12 \\
0.04 \\
0.12 \\
0.17 \\
0 \\
0.02 \\
0.07 \\
0.07 \\
0.08 \\
0.09 \\
0.21 \\
0.08 \\
0.59 \\
0.72 \\
0.63 \\
0.75 \\
0.50 \\
0.50 \\
1.00 \\
0.50\end{array}$ & $\begin{array}{c}1.33 \\
1.00 \\
1.33 \\
1.08 \\
0.95 \\
1.26 \\
1.69 \\
1.69 \\
1.08 \\
1.37 \\
1.02 \\
0.78 \\
1.23 \\
0.85 \\
1.21 \\
0.93 \\
1.58 \\
1.00 \\
1.07 \\
1.10 \\
1.31 \\
1.18 \\
1.28 \\
1.75 \\
2.25 \\
2.75 \\
1.50 \\
0.20 \\
\text { Females }\end{array}$ & $\begin{array}{l}3.44 \\
4.38 \\
2.33 \\
3.35 \\
3.95 \\
2.49 \\
2.86 \\
1.78 \\
1.01 \\
0.37 \\
0.06 \\
0.22 \\
0.42 \\
- \\
0.06 \\
0.19 \\
0.36 \\
0.14 \\
0.21 \\
0.71 \\
0.38 \\
2.34 \\
3.58 \\
2.25 \\
4.12 \\
2.50 \\
2.00 \\
5.00 \\
2.50\end{array}$ & $\begin{array}{r}15.5 \\
8.9 \\
7.0 \\
21.4 \\
39.5 \\
52.8 \\
55.2 \\
46.3 \\
19.2 \\
9.6 \\
1.5 \\
6.8 \\
11.0 \\
- \\
1.5 \\
4.3 \\
4.6 \\
1.8 \\
4.6 \\
6.9 \\
2.5 \\
26.0 \\
40.2 \\
12.0 \\
13.8 \\
8.4 \\
6.8 \\
20.7 \\
4.1\end{array}$ \\
\hline
\end{tabular}

${ }^{a} S E=$ Standard error. 
Table A-15. Breeding parameters for aquarium two, experiment two

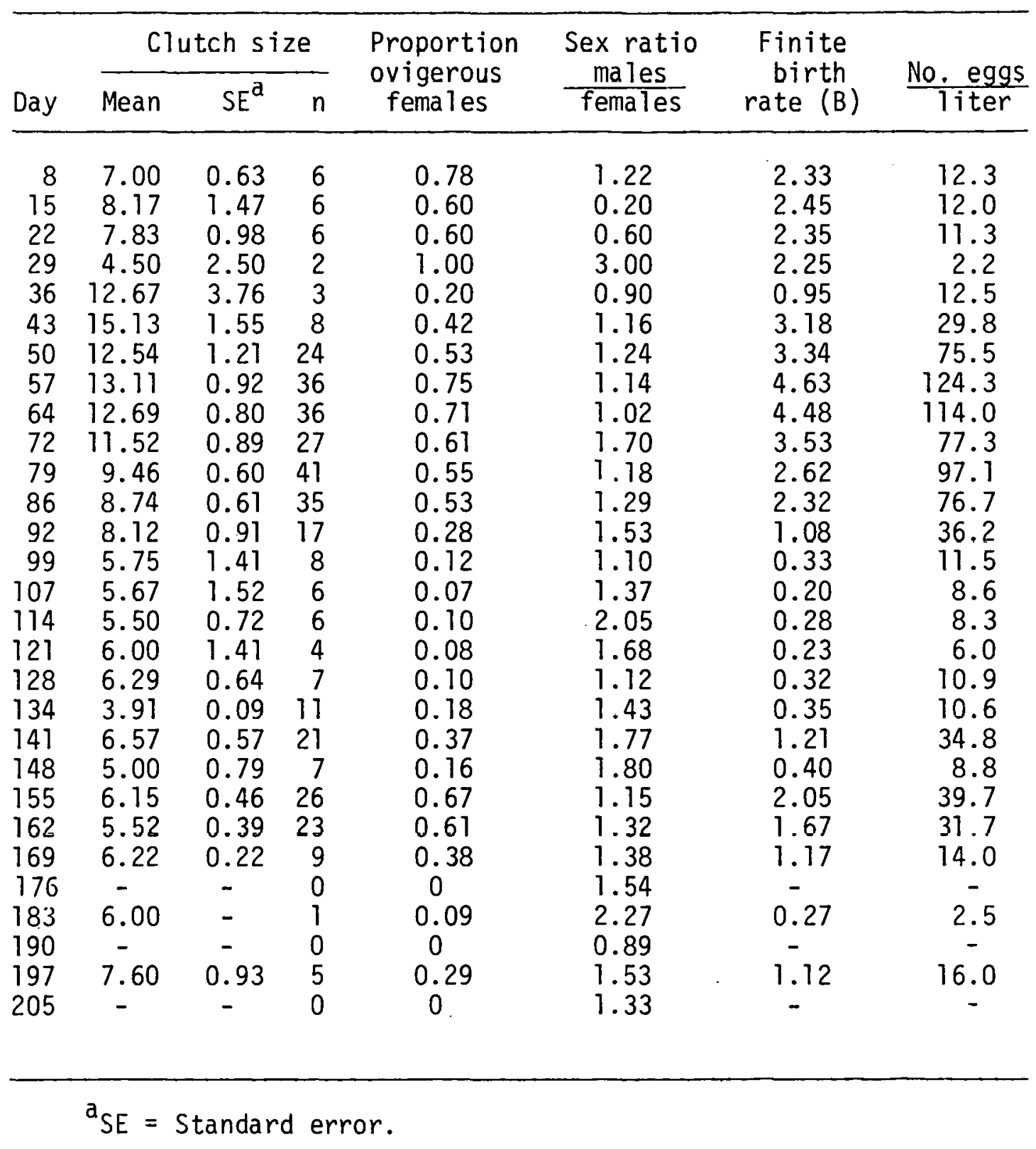


ORNL/TM- 6330

INTERNAL DISTRIBUTION
1-10. S. I. Auerbach
11. J. J. Beauchamp
12. B. G. Blaylock
13. A. S. Bradshaw
14. R. W. Brocksen
15. S. W. Christensen
16. J. D. Cooney
17. C. C. Coutant
18-29. C. W. Gehrs
30. J. M. Giddings
31. S. E. Herbes
32. J. W. Huck ab ee
33. J. S. Mattice
34. B. R. Parkhurst
35. H. Postma
36. D. E. Reichle

37. C. R. Richmond

38. D. S. Shriner

39. H. H. Shugart

40. G. R. Southworth

41. E. G. Struxness

42. J. S. Suffern

43. N. E. Tarr

44. J. R. Trabalka

45. W. Van Winkle

46. B. T. Walton

47. Biology Library

48-49. Central Research Library

50-51. Laboratory Records Dept.

52. Laboratory Records, ORNL-RC

53. ORNL Y-12 Technical Library

54. ORNL Patent Office

\section{EXTERNAL DISTRIBUTION}

55. Research and Technical Support Division, ERDA-ORO

56. C. Amundsen, Department of Ecology, University of Tennessee, Knoxville, TN 37916

57. K. Biesinger, Water Quality Laboratory, Environmental Protection Agency, 6201 Congdon Blvd., Duluth, MN 55804

58. W. J. Birge, School of Biological Science, University of Kentucky, Lexington, KY 40506

59. D. L. Bunting, Department of Zoology, University of Tennessee, Knoxville, TN 37916

60. J. G. Carlson, Department of Zoology, University of Tennessee, Knoxville, TN 37916

61. J. E. Demers, Lawler, Matusky, and Skelly Engineers, RD \#25 Danskamer Rd., Newburgh, NY 12550

62. W. T. Edmondson, Department of Zoology, University of Washington, Seattle, WA 98195

63. R. A. Goldstein, Electric Power Research Institute, P. 0. Box 10412, Palo Alto, CA 94304

64. D. Griffith, Lawler, Matusky, and Skelly Engineers, RD \#4, Oswego, NY 13126

65. D. H. Hamilton, Division of Biomedical and Environmental Research, DOE, Washington, DC 20545

66. D. Heinle, Chesapeake Biological Laboratory, Solomons, MD 20688

67. R. M. Kathman, Department of Biology, Tennessee Technological University, Cookeville, TN 38501

68. G. H. Lauff, W. K. Kellogg Biological Station, Michigan State University, Hickory Corners, MI 49060 
69. R. A. Lewis, Environmental Programs, Division of Biomedical and Environmental Research, DOE, Washington, DC 20545

70. J. J. Magnuson, Limnology Laboratory, University of Wisconsin Madison, WI 53706

71. L. A. Maguire, Department of Wildlife Sciences, College of Natural Resources, Ut ah State University, Logan, UT 84322

72. I. L. Ophe I, Biology and Health Physics Division, Atomic Energy of Canada, LTD., Chalk River Nuclear Laboratories, Chalk River, Ontario, Canada

73. A. Robertson, NOAA, Great Lakes Environmental Research Laboratory, Ann Arbor, MI 48106

74. M. H. Smith, Savannah River Ecology Laboratory, Savannah River Plant, Drawer E, Aiken, SC 29801

75. J. Swineboard, Division of Biomedical and Environmental Researeh, Elun, Washington, DC 20545

76. T. Thacker, Battelle-Pacific Northwest Laboratory, P. 0. Box 999, Richland, WA 99352

77. J. W. Whitehouse, Centrál Electricity Research Laboratories, Kelvin Avenue, Leatherhead, Surrey KT22 7SE ENGLAND

78. D. S. Woodhead, Ministry of Agriculture, Fisheries, and Foud, Fisher ies Radiobological Laboratory, Lowestoft, Suffolk, United Kingdom

79. G. M. Woodwe11, The Ecosystems Center, Marine Biological Laboratory, Woods Hole, MA 02543

80-106. Technical Information Center, Oak Ridge, TN 37830 